\title{
Phytochemistry, Ethnopharmacology, Pharmacokinetics and Toxicology of Cnidium monnieri (L.) Cusson
}

\author{
Yue Sun ${ }^{\mathbb{D}}$, Angela Wei Hong Yang $\mathbb{D}$ and George Binh Lenon * $\mathbb{D}$ \\ School of Health and Biomedical Sciences, RMIT University, Melbourne 3083, Australia; \\ s3574776@rmit.edu.au (Y.S.); angela.yang@rmit.edu.au (A.W.H.Y.) \\ * Correspondence: george.lenon@rmit.edu.au; Tel.: +61-3-99256587
}

Received: 5 December 2019; Accepted: 27 January 2020; Published: 3 February 2020

check for updates

\begin{abstract}
Cnidium monnieri (L.) Cusson (CMC) is a traditional Chinese herbal medicine that has been widely grown and used in Asia. It is also known as "She chuang zi" in China (Chinese: 蛇 床子), “Jashoshi” in Japan, “Sasangia" in Korea, and "Xa sang tu” in Vietnam. This study aimed to provide an up-to-date review of its phytochemistry, ethnopharmacology, pharmacokinetics, and toxicology. All available information on CMC was collected from the Encyclopedia of Traditional Chinese Medicines, PubMed, EMBASE, ScienceDirect, Scopus, Web of Science, and China Network Knowledge Infrastructure. The updated chemical structures of the compounds are those ones without chemical ID numbers or references from the previous review. A total of 429 chemical constituents have been elucidated and 56 chemical structures have been firstly identified in CMC with traceable evidence. They can be categorized as coumarins, volatile constituents, liposoluble compounds, chromones, monoterpenoid glucosides, terpenoids, glycosides, glucides, and other compounds. $\mathrm{CMC}$ has demonstrated impressive potential for the management of various diseases in extensive preclinical research. Since most of the studies are overly concentrated on osthole, more research is needed to investigate other chemical constituents.
\end{abstract}

Keywords: she chuang zi; cnidii fructus; herbal medicine; natural product; phytotherapy

\section{Introduction}

Cnidium monnieri (L.) Cusson. (CMC) is the dry fruit of the Umbelliferae plant Cnidium monnieri (L.) from the Apiaceae family. Figure 1A shows the medicinal plant of Cnidium monnieri (L.). Its pharmaceutical name, English name and Chinese Pinyin name are Cnidii Fructus, Cnidium seed, and She chuang zi, respectively. As this herb is widely grown in China, Japan, Korea, and Vietnam, it is also known as "Jashoshi" in Japanese, "Sasangia" in Korean, and "Xa sang tu" in Vietnamese. In China, $\mathrm{CMC}$ is grown in most parts of the country. The main growing provinces are Hebei, Jiangsu, Zhejiang, Shandong, and Sichuan (Figure 1B). The first record of CMC was in Shennong's Classic of Materia Medica (Shen Nong Ben Cao Jing). As for its properties, CMC is acrid, bitter, warm, and slightly toxic [1]. According to the latest review of CMC, 364 of its components have been identified, which mainly include coumarins such as osthole, imperatorin, bergapten, isopimpinellin, xanthotoxol, xanthotoxin, cnidimonal, cnidimarin, and glucosides. CMC is renowned for its broad range of pharmaceutical properties to treat female genitals, male impotence, frigidity, skin diseases and exerting antipruritic, anti-allergic, antidermatophytic, antibacterial, antifungal, and anti-osteoporotic effects [1]. Since the earlier review covered up to 2015, and more research projects have been conducted regarding CMC since then, it is necessary to update the relevant knowledge in a timely manner. This study thus aimed to provide an up-to-date review on the phytochemistry, ethnopharmacology, pharmacokinetics, and toxicology of CMC. 

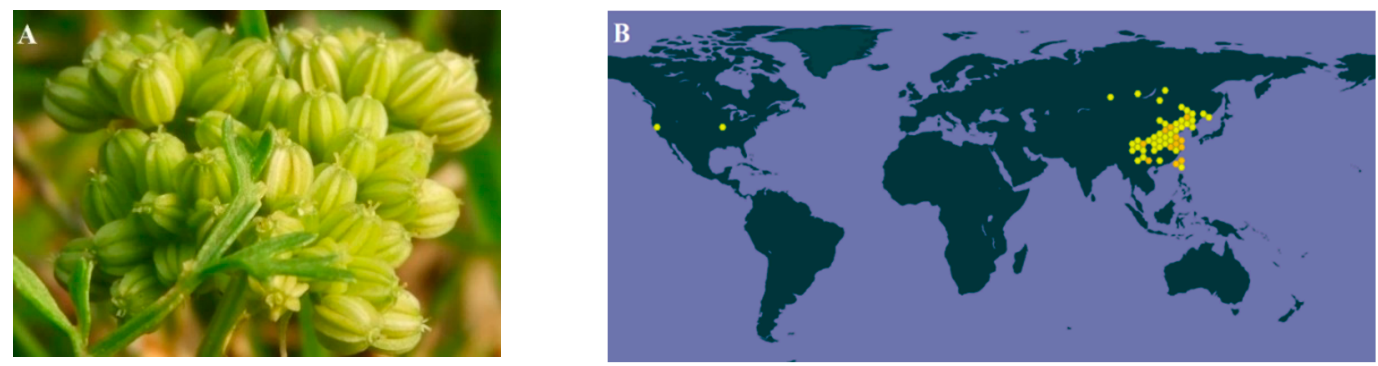

Figure 1. (A) The medicinal plant of Cnidium monnieri (L.), created by Penny Wang and published by iNaturalist (Record license http://creativeco...censes/by-nc/4.0/). (B) the global distributions of Cnidium monnieri (L.) Cusson (https://www.gbif.org/species/3034720). CMC is mainly grown in China, Japan, Korea, and Vietnam and scarcely grown in America and the Russian Far East.

\section{Results}

A total of 1176 studies were identified through the literature search, of which 901 studies were excluded due to duplication, or no mention of phytochemistry, pharmacology, pharmacokinetics, or toxicology. Two hundred and seventy-five studies are thus included in this review. Among them, 72 studies correspond to phytochemistry, 188 studies are on pharmacology and 12 studies are related to pharmacokinetics and toxicology, three studies did not belong to any of these three categories but feel within the scope of this study. The study selection process is illustrated in Figure 2.

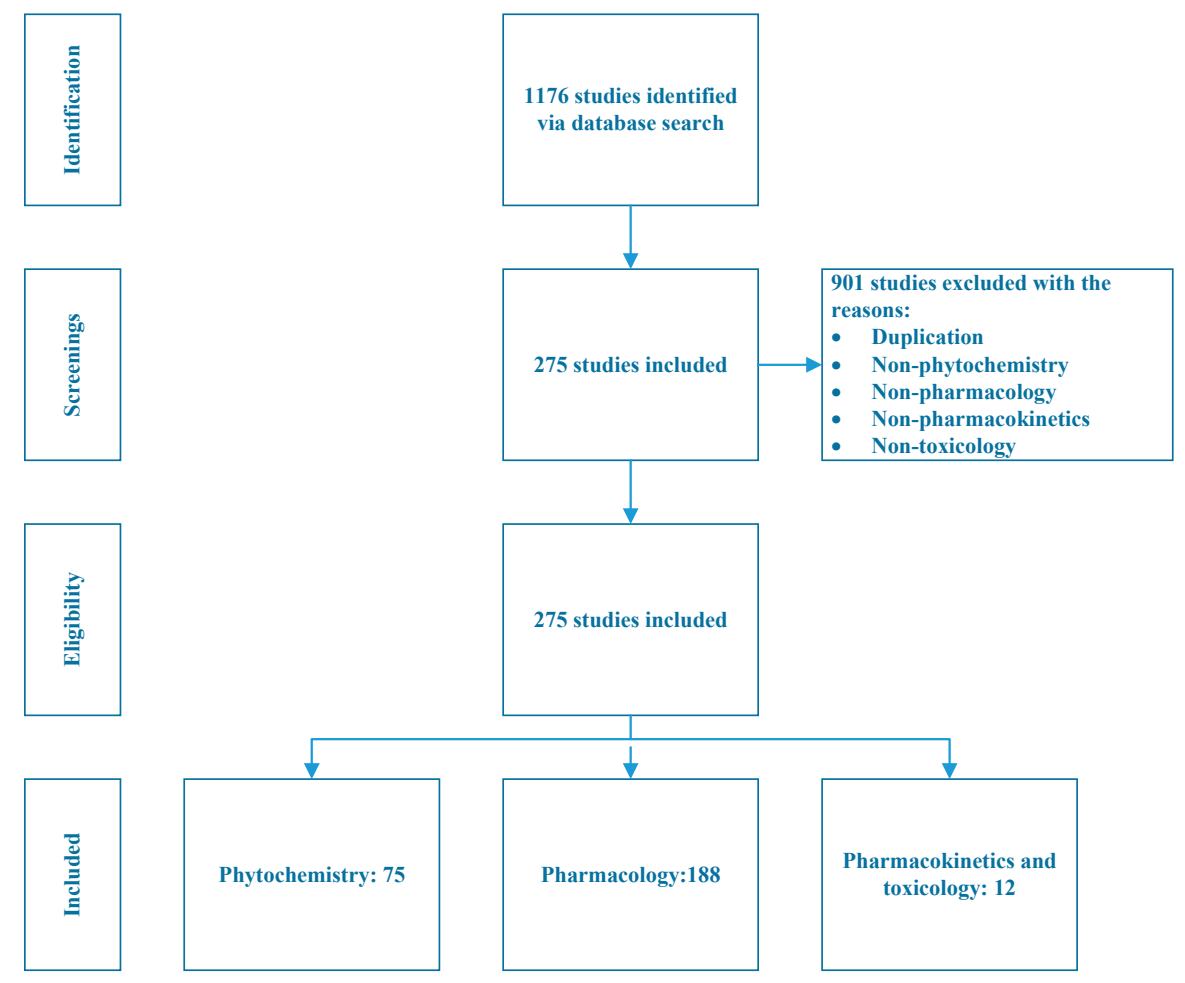

Figure 2. Study selection process for included studies related to Cnidium monnieri (L.) Cusson.

\subsection{Phytochemistry}

In total 429 chemical constituents have been elucidated and 56 chemical structures (Table 1) have been revealed for the first time in CMC with traceable evidence. They can be categorized as coumarins, volatile constituents, liposoluble compounds, chromones, monoterpenoid glucosides, terpenoids, glycosides, glucides, and other compounds. 
Table 1. Molecular formula and chemical structures of compounds derived from Cnidium monnieri (L.) Cusson (80 in total, 56 with chemical structures).

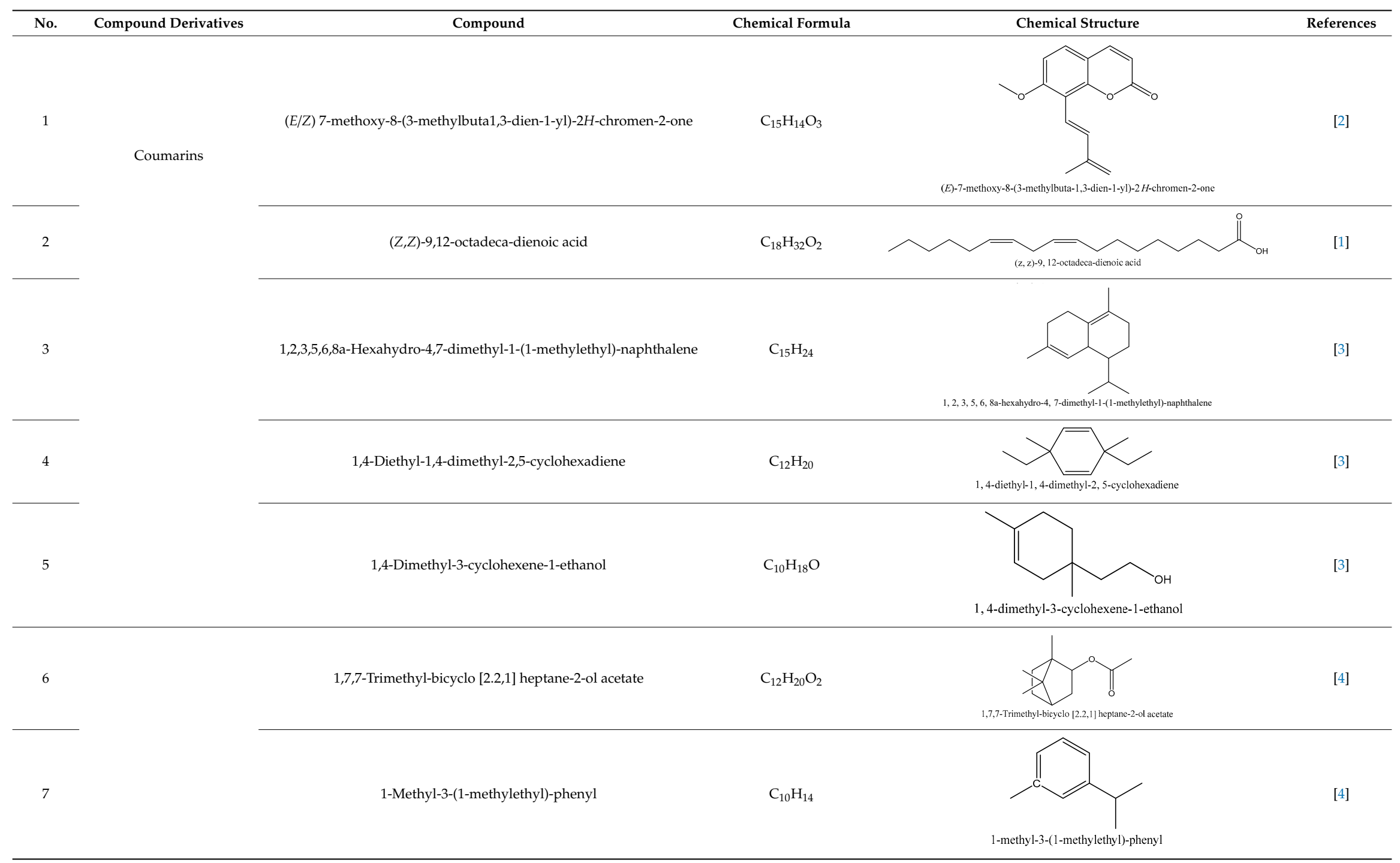


Table 1. Cont.

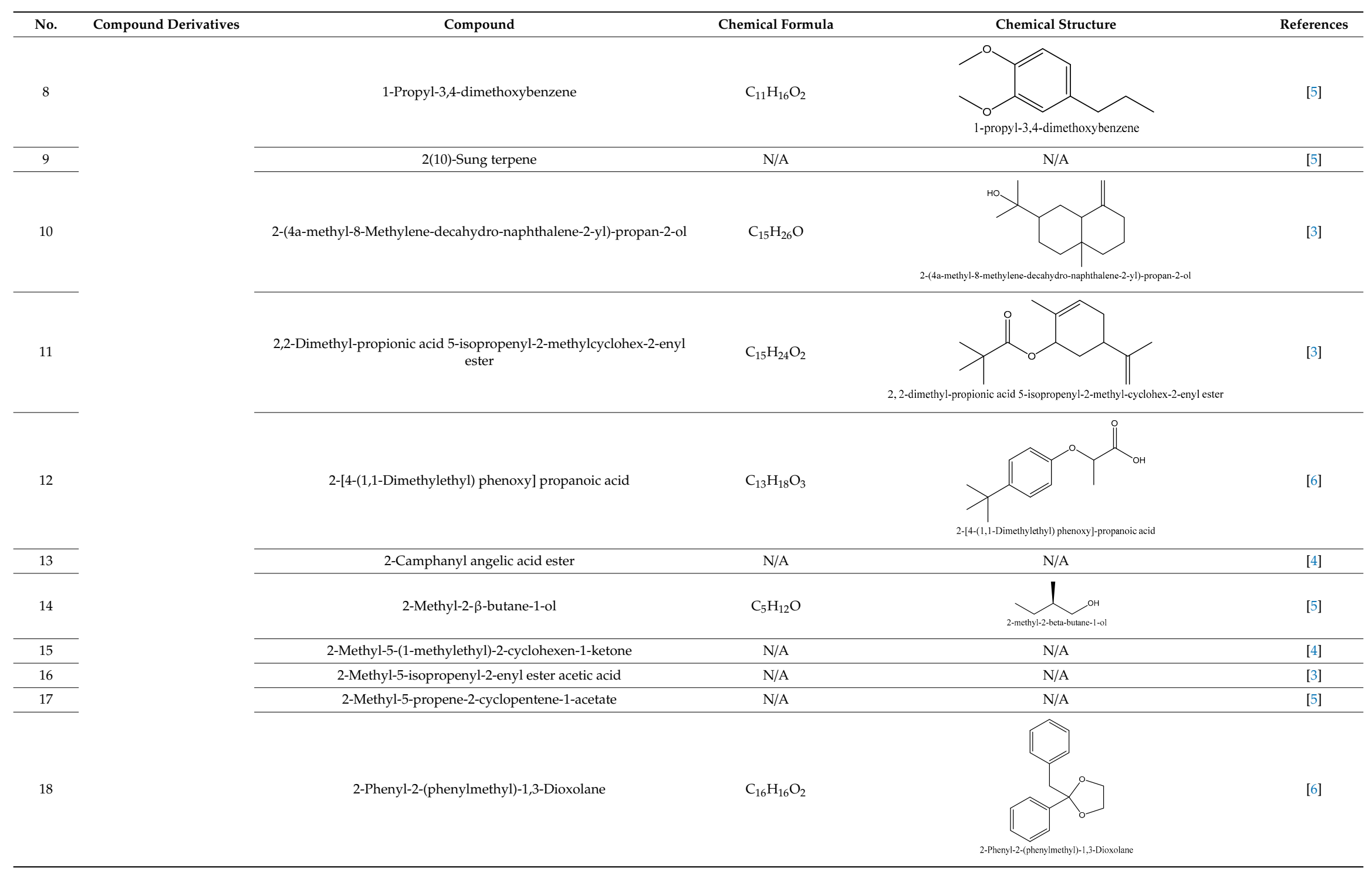


Table 1. Cont.

\begin{tabular}{|c|c|c|c|c|c|}
\hline No. & Compound Derivatives & Compound & Chemical Formula & Chemical Structure & References \\
\hline 19 & & 3,7-Dimethyl-3(E)-octene-1,2,6,7-tetraol & $\mathrm{C}_{10} \mathrm{H}_{20} \mathrm{O}_{4}$ & dimethyl-3(E)-octene 1,2,6,7-te & [7] \\
\hline 20 & & 4-(1-Methylethyl)-benzyl alcohol & $\mathrm{C}_{10} \mathrm{H}_{14} \mathrm{O}$ & benzy & [4] \\
\hline 21 & & 4-Methyl-1-(1-methylethyl)-2-cyclohexene-1-ol & $\mathrm{C}_{10} \mathrm{H}_{18} \mathrm{O}$ & |l-1-(1-methylethyl)-3-cyclohex & [3] \\
\hline 22 & & 4-Methyl-1-(1-methylethyl)-3-cyclohexaen-1-ol & $\mathrm{C}_{10} \mathrm{H}_{18} \mathrm{O}$ & |1-1-(1-methylethyl)-3-cyclohex & [8] \\
\hline 23 & & 4- $\alpha$-Hydroxydihydro-furan agar & N/A & N/A & [4] \\
\hline 24 & & 5,5-Dimethyl-8-methylene-1,2-epoxycyclooct-3-ene & $\mathrm{C}_{11} \mathrm{H}_{16} \mathrm{O}$ & thyl-8-methylene-1, 2-ppoxycycl & [3] \\
\hline 25 & & 5-Isopropenyl-2-methyl-cyclohex-2-enyl propionic acid ester & N/A & N/A & [3] \\
\hline 26 & & 5-Isopropenyl-3-methyl-cyclohex-1-enol & $\mathrm{C}_{10} \mathrm{H}_{16} \mathrm{O}$ & propenyl-3-methyl-cyclohex-1 & [3] \\
\hline 27 & & 5-Propene-2-cyclopenten-1-ol & N/A & N/A & [5] \\
\hline
\end{tabular}


Table 1. Cont.

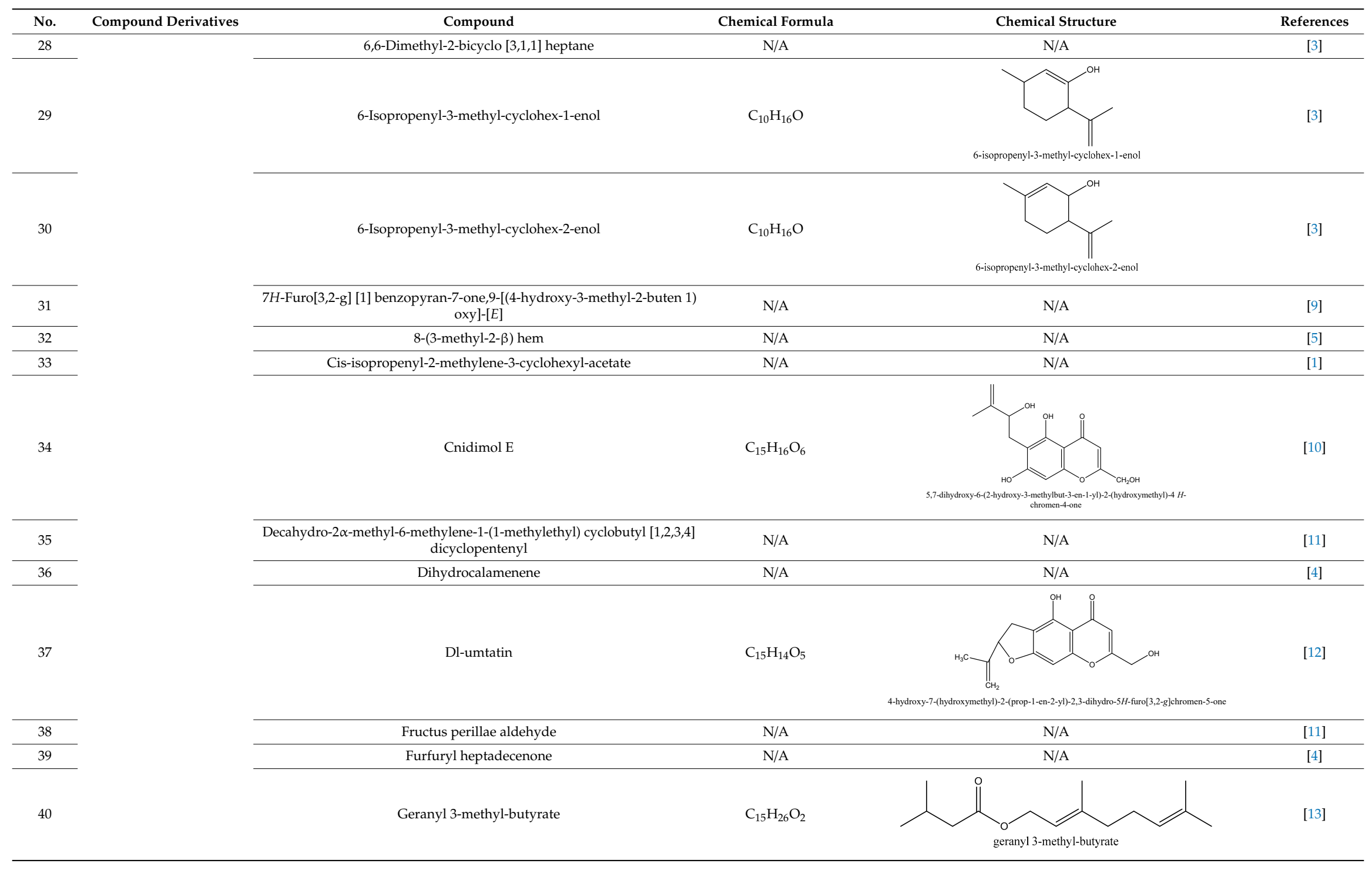


Table 1. Cont.

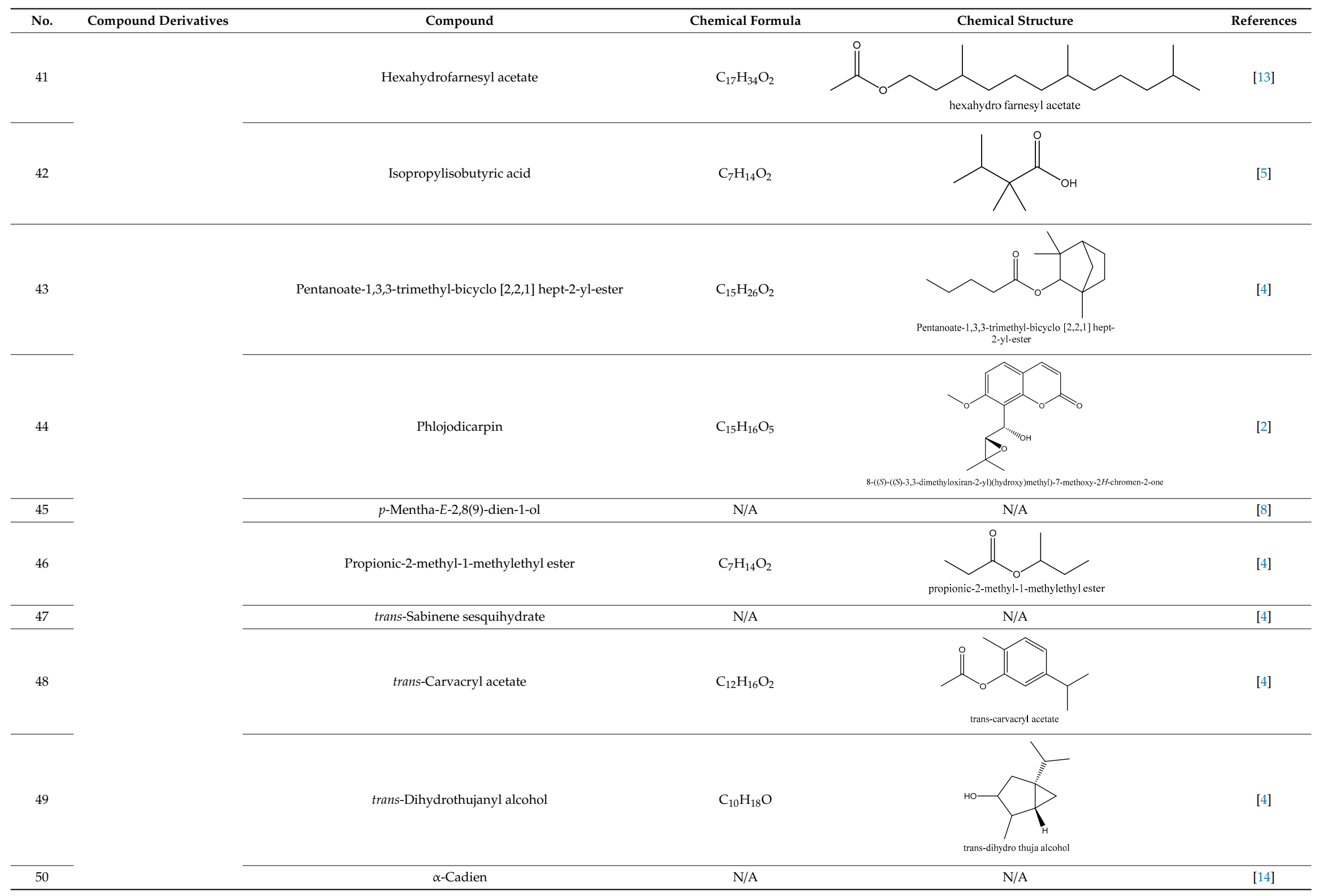


Table 1. Cont.

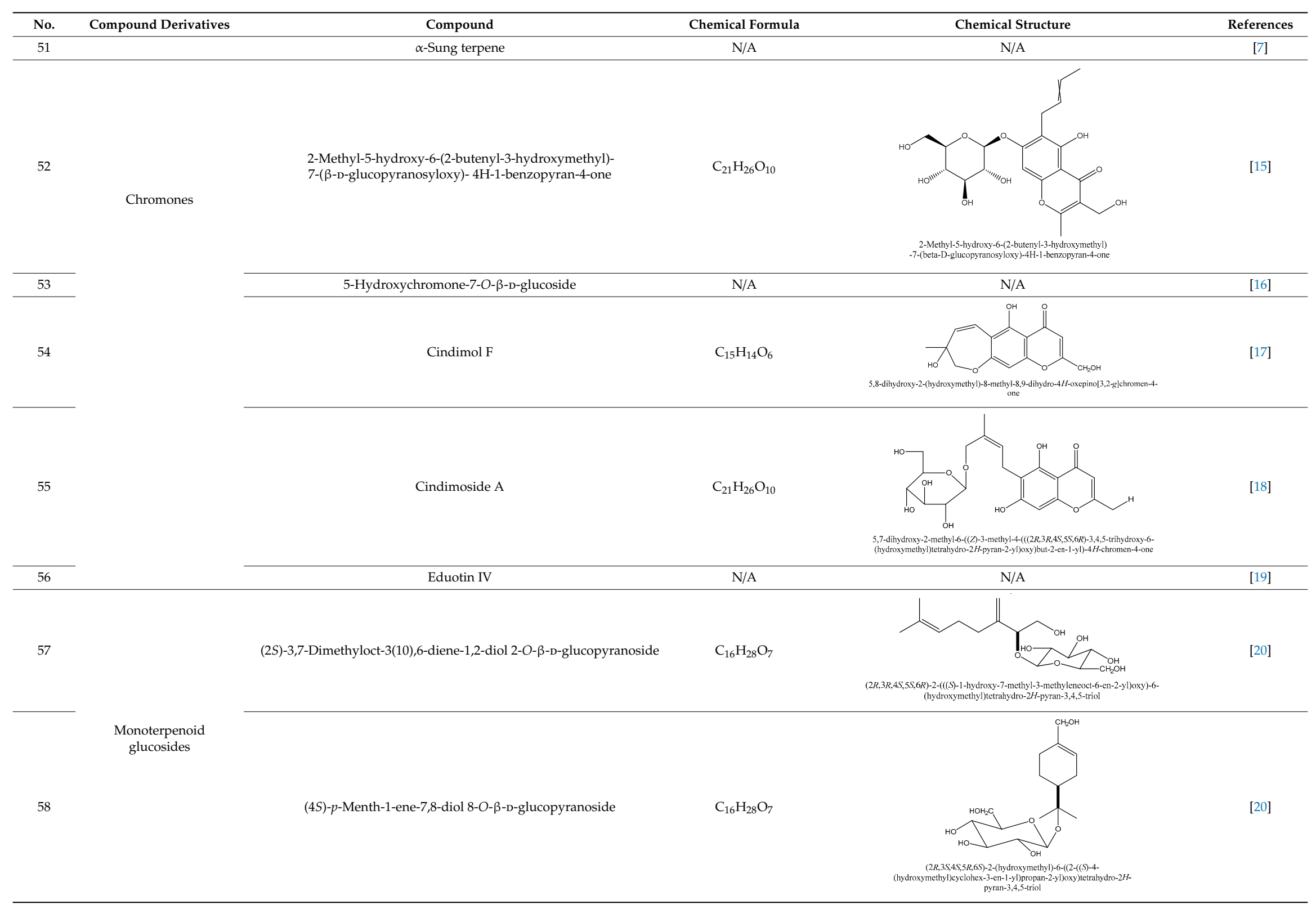


Table 1. Cont.

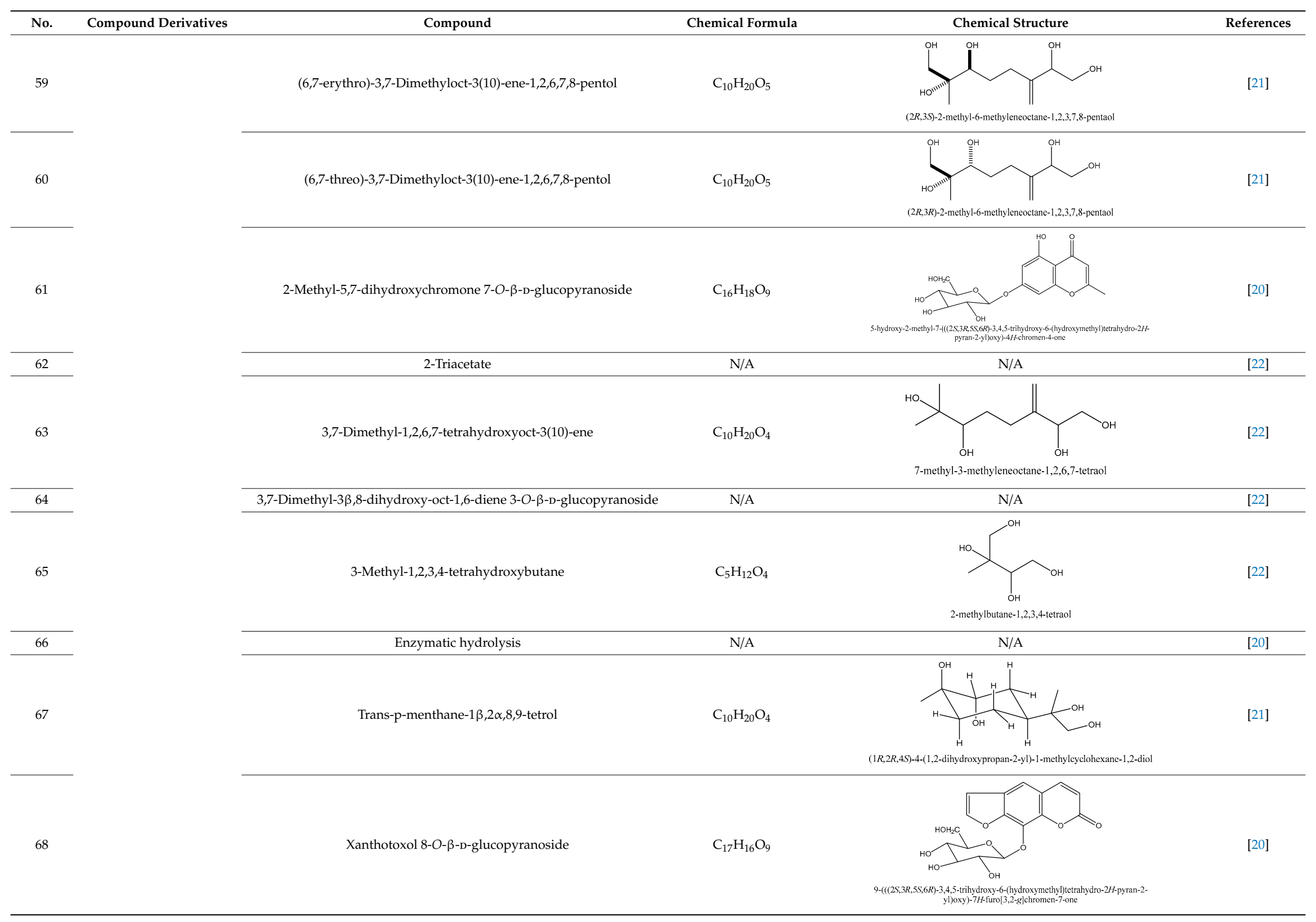


Table 1. Cont

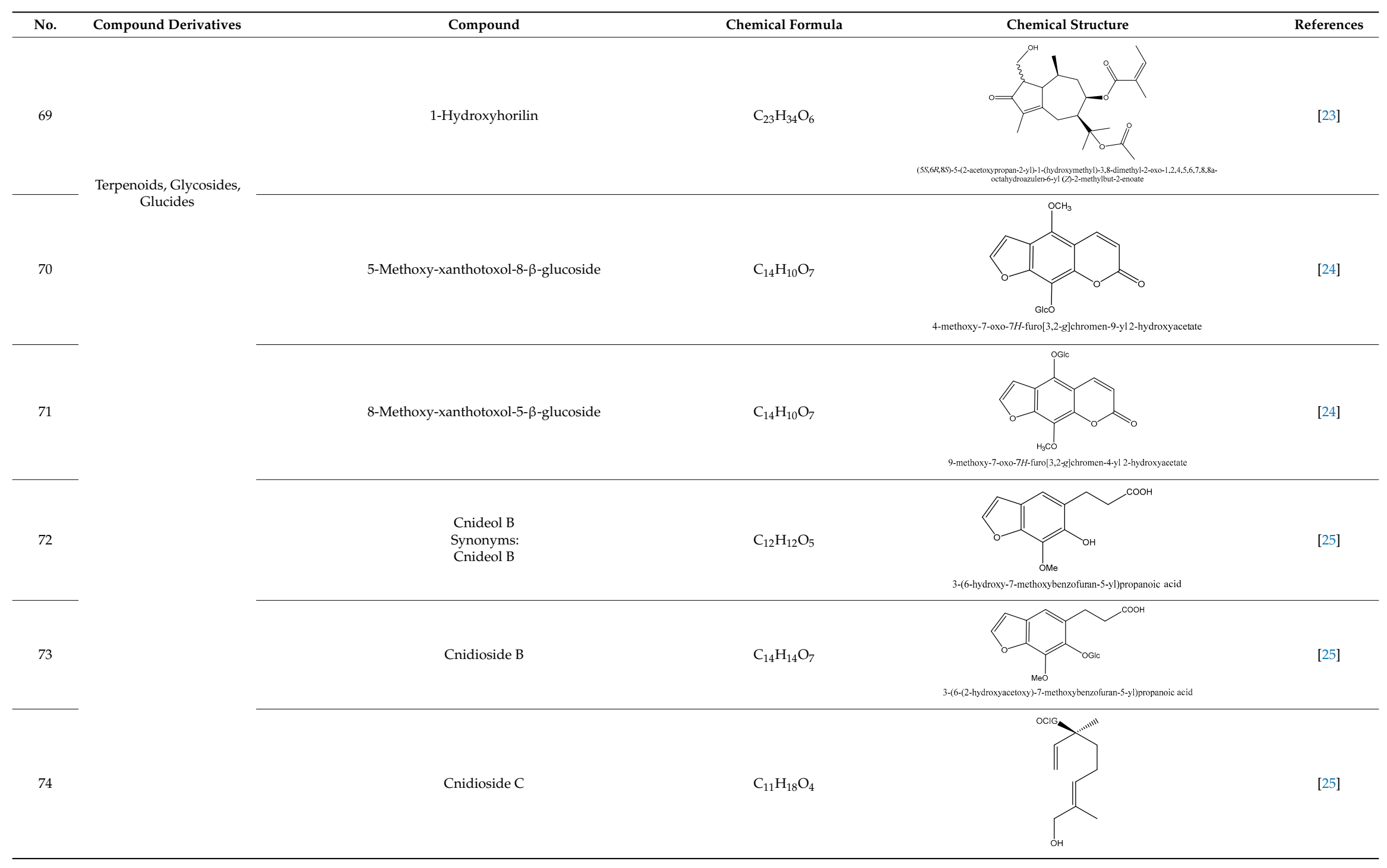


Table 1. Cont.

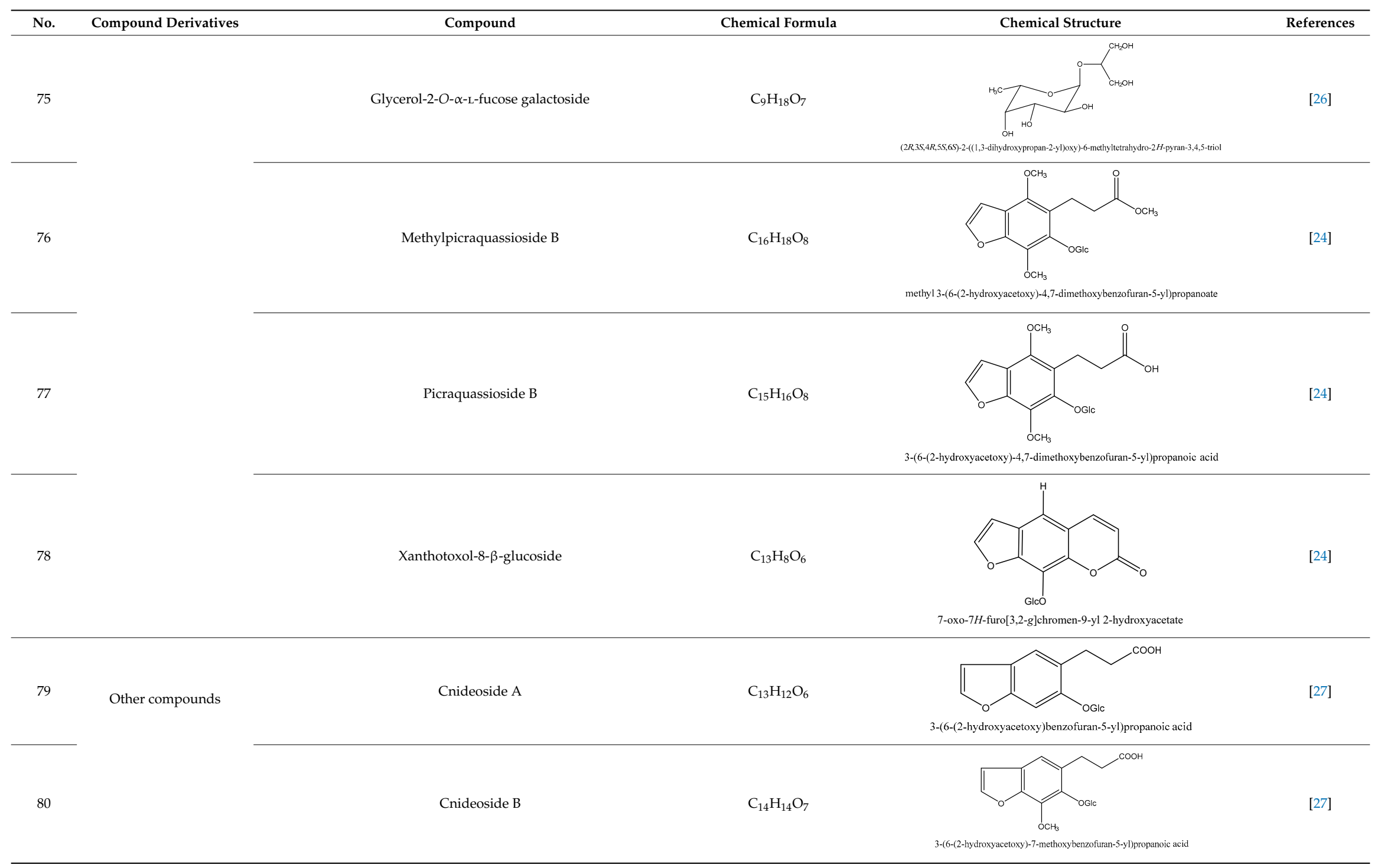




\subsubsection{Coumarins}

Coumarins are the general term for family natural compounds which possess a benzoquinone $\alpha$-pyran one core. They mainly exist in the flowers, stems, leaves, and fruits of Umbelliferae and Rutaceae plants in the free state form or in combination with sugars to form glycosides. In terms of pharmacological effects, coumarins possess anti-hypertension, anti-inflammatory, analgesic, and anticancer effects [28,29]. Coumarins include $2^{\prime}$-acetylangelicin, bergapten, imperatorin, osthole, isoimperatorin, isopimpinellin, xanthotoxin, columbianetin, isoporalen, fraxetin, 6,7,8-trimethoxycoumarin, murrayacarpin A, limettin, scoparone, isofraxidin, 7-methoxy-8-formylcoumarin, 2'-deoxymeranzin hydrate, oxypeucedanin hydrate, peroxymurraol, peroxy-auraptenol, auraptenol, micromarin-F, demethylauraptenol, albiflorin-3, osthenol, 7-demethyl-suberosin, cnidilin, angenomalin, meranzin hydrate, cnidimoside A, kaempferol, isorhamnetin, quercitrin, luteolin, quercetin, hesperidin, rutin, psoralen, oxypeucedanin, cnidimol D, 2'-hydrate-deoxymeranin, phlojodicarpin, (E/Z)-7-methoxy-8-(3-methylbuta1,3-dien-1-yl)-2H-chromen-2-one, karenin, columbianadin, cniforin A, daucosterol, xanthotol, O-isovalerylcolumbianetin, iisogosferol, archangelicin, ( $\left.3^{\prime} R\right)-3^{\prime}$-hydroxycolumbianetin, cniforin B, 6-methoxy-8-methylcoumafin, cnidimonal, cnidimarin, $\quad 1^{\prime}-O-\beta$-D-glucopyranosyl (2R,3S)-3-hydroxynodakenetin, 7-O-methylphellodenol-B, 7-methoxy-8-(3-methyl-2,3-epoxy-1-oxobutyl)chromen-2-one, 3'-O-methylvaginol, hassanone, E-murraol, Z-murraol, $3^{\prime}-O$-methylmurraol, Rel-(1'S, $\left.2^{\prime} S\right)-1^{\prime}-O$ - methylphlojodicarpin, $\left(1^{\prime} S, 2^{\prime} S\right)-1^{\prime}-O$-methylvaginol, and isobergapten.

\subsubsection{Chromones}

Chromones are a family of compounds extensively distributed in Nature with multiple biological activities that include antitumor, antimicrobial, antiviral, anti-inflammatory, and antioxidant effects [30]. The isolated chromone chemical compounds are cnidimol B, peucenin, 5,7-dihydroxychromone, 5-O-methylvisamminol, 4'-O- $\beta$-D-glucosyl-5-O-methylvisamminol, hamaudol, 2,5-dimethyl-7-hydroxychromone, cimifugin, 5-hydroxychromone-7-O- $\beta$-D-glucoside, eduotin IV, oroselone, cnidimol A, cindimol $\mathrm{F}$, cindimoside $\mathrm{A}$, hydroxycnidimoside $\mathrm{A}$, undulatoside $\mathrm{A}$, saikochromoside $\mathrm{A}$, cnidimoside $\mathrm{B}$, 2-methyl-5-hydroxy-6-(2-butenyl-3-hydroxymethyl)-7-( $\beta$-D-glucopyranosyloxy)-4H-1-benzopyran- 4-one, monnieriside $A$, monnieriside $B$, monnieriside $C$, monnieriside $D$, monnieriside $E$, monnieriside $F$, monnieriside $G$, and $6^{\prime}$-mydroxylangelicain.

\subsubsection{Triterpenoids, Glycosides, and Glucides}

Triterpenoids are compounds with a carbon skeleton based on six isoprene units evolved from the acyclic $C_{30}$ hydrocarbon squalene [31]. Glycosides are compounds where the hemiacetal or hemiketal hydroxyl groups of a monosaccharide is condensed with the hydroxyl group of a second molecule with water elimination. Cnidioside B is a representative compound in this category [32]. Glucides can be represented by glycerol-2-O- $\alpha$-L-fucopyranoside and 6-deoxy-D-glucitol [PubChem CID: 151266] [1].

\subsubsection{Monoterpenoid Glucosides}

The main chemical compounds in this category are 3,7-dimethyloct-1-ene-3,6,7-triol 3-O- $\beta$-D-glucopyranoside, $\quad(2 S, 6 S)-3,7$-dimethyloct-3(10)-ene-1,2,6,7-tetrol $\quad 2-O-\beta$-D-Glucopyranoside, (4S)-p-menth-1-ene-7,8-diol 8-O- $\beta$-D-glucopyranoside $\quad[20], \quad 3,7$-dimethyloct-1-ene-3,6,7-triol 3-O- $\beta$-D-gluco-pyranoside, Enzymatic hydrolysis, (2S)-3,7-dimethyloct-3(10),6-diene-1, 2-diol 2-O- $\beta$-D-gluco-pyranoside, $\quad(4 S)$ - $p$-menth-1-ene- $\quad 7,8$-diol $\quad 8$-O- $\beta$-D-glucopyranoside, $\quad\left(3^{\prime} R\right)$ -hydroxymarmesin 4'-O- $\beta$-D -glucopyranoside, xanthotoxol 8-O- $\beta$-D-glucopyranoside, 2-methyl-5,7-dihydroxychromone 7-O- $\beta$-D-glucopyranoside, 3,7-dimethyloctane-1,2,6,7-tetrol, (6,7-threo)-3, 7-dimethyloct-3(10)-ene-1,2,6,7,8-pentol， (6,7-erythro)-3， 7-dimethyloct-3(10)-ene-1,2,6,7,8-pentol, 
3,7-dimethyl-1， 2,6,7-tetrahydroxy-oct -3(10)-ene,1-Triacetate, 3-methyl-1,2,3,4-tetrahydroxy-butane 2 -triacetate, and 3,7-dimethyl-3 $\beta, 8$-dihydroxy-oct-1,6-diene 3-O- $\beta$-D-glucopyranoside.

\subsubsection{Liposoluble Compounds}

Liposoluble compounds in this category can be represented by 2,4-dimethylhexane and 38 other compounds. Among these compounds, phytol (15.98\%), hexadecenoic acid (12.73\%), 9,12,15-octadecatrienoic acid (11.02\%), 9-octadecenoic acid [PubChem CID: 637517] (6.33\%) and 9,12-octadecadienoic acid (4.77\%) are the main constituents of the liposoluble constituents in the fruit of CMC [33].

\subsubsection{Volatile Oil}

In this group, according to the CMC sample from Shandong Province in China, the highest concentration substance is limonene $(18.90 \%)$, followed by $\alpha$-pinene $(16.40 \%)$, borneyl acetate $(11 \%)$, camphene $(7.44 \%)$, osthol $(5.24 \%), \quad \beta$-pinene $(3.43 \%)$, L-borneol $(1.58 \%)$, and hexadecenoic acid (1.05\%) according to a GC-MS analysis method [34]. The identified compounds include $\alpha$-pinene, camphene, limonene, bornyl acetate, 2-phenyl-2-(phenylmethyl)-1,3-dioxolane, cyclobutanol, pyruvic acid, 8-hexyl-8-pentylhexadecane, 1,2,4-benzenetricarboxylic acid-1,2-dimethyl ester, 2-[4-(1,1-dimethylethyl)phenoxy]-propanoic acid, 2-methyldocosane, $O$-acetylcolumbianetin, isopropyl-3-methylbutanoate, tricyclene, $\beta$-pinene, myrcene, $\alpha$-terpinene, 3-7-dimethyl-1,3,7-octatriene, $\beta$-ocimene, $\gamma$-terpinene, cis-sabinene hydrate, terpinolene, 1,3,8-p-menthatriene, sabinene hydrate, linalool oxide, $p$-mentha-1,5,8-triene, trans- $p$-2,8-menthadien-1-ol, neo-allo-ocimene, camphor, $p$-mentha-2,8-dien-1-ol, L-borneol, 4-methyl-1-(1-methylethyl)-3-cyclohexen-1-ol, cis-dihydrocarvone, bicycle[5.1.0]octane,, $\alpha$-fenchyl acetate, perillyl alcohol, 3,7-dimethyl-8-(1-methylethylidene)-2,6-octadienoic acid methyl ester, carvyl acetate, neryl acetate, $\alpha$-copaene, $\beta$-bourbonene, $\beta$-farnesene, germacrene $D, \beta$-bisabolene, $\delta$-cadinene, caryophyllene oxide, geranyl pentanoate, cis-asarone, 6,10,14-trimethyl-2-pentadecanone, 3-carene, D-limonene, 1-methyl-4-(1-methylethyl)-cyclohexene, 2,6-dimethyl-2,4,6-octatriene, 2-isopropenyl-3-methylenecyclohexanol, acetic acid 2-methyl-5-isopropenyl-2-enyl ester, neryl phenylacetate, 7,11-dimethyl-3-methylene-1,6,10-dodecatriene, eudesma-4(14),11-diene, 3-methyl-2-phenylethyl butanoic acid ester, $\alpha$-farnesene, 3,7-dimethyl-2,6-octadienyl butanoic acid ester, 1,2,3,5,6,8a-hexahydro-4,7-dimethyl-1-(1-methylethyl)-naphthalene, 1,4-diethyl-1,4-dimethyl-2,5-cyclohexadiene, $1 H$-indole-3-butanoic acid, 6-isopropenyl-3-methyl-cyclohex-1-enol, 2-(4a-methyl-8-methylene-decahydro-naphthalene -2-yl)-propan-2-ol, tricyclo [4.3.1.0(3, 8)] decan-10-ol, 2,2-dimethylpropionic acid 5-isopropenyl-2-methylcyclohex-2-enyl ester, allyl phenoxyacetate, 5,5-dimethyl-8-methylene-1,2-epoxycyclooct-3-ene, 6-isopropenyl-3-methyl-cyclohex-2-enol, 2-pentacosanone, (Z,Z)-9,12-octadeca-dienoic acid, E-9-tetradecenoic acid, pentatriacontane, (Z)-3-heptadecen-5-yne, tetratetracontane, $\alpha$-cadien, asaron, carveol, cnidiadin, diosmetin, Dl-umtatin, cnidimol C, cnidimol E, 5-formylxanthotoxol, edultin, $\left(3^{\prime} R\right)$ - $3^{\prime}$-hydroxy-columbianedin, 3,7-dimethyl-3(E)-octene-1,2,6,7-tetraol, L-camphene, bornyl isovalerate, 2-butene, 2-methylacrolein, toluol, isobutyric acid isopropyl ester, 2-ethylidene-1,1-dimethylcyclopentane, 2-methylbutyric acid isopropyl ester, pentanoate isopropyl ester, 1,7,7-trimethylbicyclo [2.2.1] heptane, 4(10)-thujene, 1,4,8-menthatriene, p-cymene, 3,5-dimethylstyrene, 1,3,7-octatriene,3-7-dimethyl-1,5,8-menthatriene, 2,2,3-trimethyl-(R)-3-cyclopentene-1-acetaldehyde, 1-methyl-4-(1-methyl-ethenyl)-7-oxabicyclo[4,1,0]heptane, myrtenol, dihydrocarvone, verbenone, trans-carveol, carvol, pinocamphone, isopiperitenone, fructus perillae aldehyde, Z-methyl geranate, geranyl acetate, benzyl isovalerate, phenethyl isobutyrate, decahydro-2 $\alpha$-methyl-6-methylene-1-(1-methylethyl) cyclobutyl $[1,2,3,4]$ dicyclopentenyl, trans-caryophyllene, geranyl isobutyrate, $\beta$-eudesmol, cyclofenchene, $\beta$-terpinene, isoborneol, azulene, $1(7), 8(10)-p$-menthadien-9-ol, dipentene oxide, $\alpha$-cubebene, $\alpha$-bergamotene, $\alpha$-elemene, dimethyl ketene, undecane, cis-carveol, $7 \mathrm{H}$-furo[3,2-g] [1] benzopyran-7-one,9-[(4-hydroxy-3-methyl-2-buten 
1) oxy]-[E], nerolidol, nerolidol isomer, cis-isopropenyl-2-methylene-3-cyclohexyl-acetate, propionate, tert-butyl phenyl acetate, diisobutyl phthalate, linoleic acid, oleic acid, stearic acid, arachidic acid, ethyl arachidate, propionic-2-methyl-1-methylethyl ester, nonane, $\alpha$-methylbenzyl ethanol, trans-sabinene hydrate, hydroxycitronellal, 1-methyl-4-(1-methylethenyl) cyclohexene, $\beta$-terpineol, $\alpha$-pinene oxide, vanillin, 4-(1-methylethyl)-benzyl alcohol, 3-cyclohexene-1-methanol, $\alpha, \alpha, 4$-trimethyl-2-butyl-1-methylpyrrolidine, pentanoate-1,3,3-trimethylbicyclo [2,2,1] hept-2-yl-ester, 1-methyl-3-(1-methylethyl)phenyl-2-methyl-5-(1-methylethyl)-2-cyclohexen-1-ketone, $\beta$-dihydrofuran, 1,7,7-trimethylbicyclo[2.2,1] heptane-2-ol acetate, 14-hydroxycaryophyllene, trans-carvacryl acetate, $\alpha$-muurolene, cubenol, trans-dihydro thuja alcohol, bicyclogermacrene, dihydrocalamenene, 6-methyl- $\alpha$-ionone, trans-sabinene sesquihydrate, widdrol, 4- $\alpha$-hydroxydihydro-furan-agar, $\alpha$-bisabolol, 2-camphanyl angelic acid ester, methyl jasmonate, furfuryl heptadecenone, cis,cis-farnesol, 3-methyl-2-butene-1-ol, 2-pentyl-furan, dehydro- $p$-cymene, nonanal, $\beta$-linalool, fenchol, 2,6-dimethyl-1,3,5,7-octatetraene, $\alpha$-terpinenol, thymol methyl ether, undecanal, ylangene, $\beta$-elemene, dodecanal, isocaryophyllene, $\alpha$-cedrene, $\alpha$-santalene, thujopsene, $\alpha$-caryophyllene, acoradiene, $\beta$-chamigrene, $\gamma$-muurolene, 2 -tridecanone, $\beta$-himachalene, ar-curcumene, $\gamma$-elemene, $\alpha$-cadinene, $\alpha$-longipinene, $\alpha$-himachalene, germacrene $B$, perillyl acetate, geranyl propionate, geranyl 3-methylbutyrate, myristic acid, hexahydrofarnesyl acetate, 3,7,11,15-tetramethyl-2-hexadecen-1-ol, palmitoleic acid, 2-methyl-2- $\beta$-butane-1-ol, isopropylisobutyric acid, $\alpha$-sung terpene, 2(10)-sung terpene, pentylbenzene, 1,3,3-trimethylbicyclo [2.2.1] heptan-2-ol 2-acetate, 5-propene-2-cyclopenten-1-ol, 2-methyl-5-propene-2-cyclopentene-1-acetate, 1-phenyl-1-pentanone, 1-propyl-3,4-dimethoxybenzene, $\alpha$-selinene, cinnamyl acetate, cedrol, 8-(3-methyl-2- $\beta$ ) hem, $p$-mentha-e-2,8(9)-dien-1-ol, 3-cyclohexaen-1-ol, 4-methyl-1-(1-methylethyl)-3-cyclohexaen-1-ol, octadecanal, 1-octadecene, (3ß,24S)-stigmast-5-en-3-ol, 6,6-dimethyl-2-bicyclo [3,1,1] heptane, 4-methyl-1-(1-methylethyl)-2-cyclohexene-1-ol, $\quad$ 5-isopropenyl-2-methyl-cyclohex-2-enyl propionic acid ester, 1,4-dimethyl-3-cyclohexene-1-ethanol, tricyclo [4.4.0.0 (2,8)] decan-4-ol, and 5-isopropenyl-3-methyl-cyclohex-1-enol.

\subsubsection{Liposoluble Compounds}

The chemical compounds in this category include 2,4-dimethylhexane, 2,3-dimethylhexane, 2,3,4-trimethylhexane, 2-methylheptane, 3-methylheptane, octane, 5-ethyl-2,4-dimethyl-2-heptene, 1,2,5,5-tetramethyl-1,3-cyclopentadiene, heptadecane, Z-11-tetradecenoic acid, octadecane, pentadecanoic acid, nonadecane, (Z)-7-hexadecenoic acid, eicosane, heptadecanoic acid, 6,9,12-octadecatrienoic acid, 9,12-octadecadienoic acid, 9,12,15-octadecatrienoic acid, phytol, 7,10,13-eicosatrienoic acid, heneicosane, docosanoic acid, tricosanoic acid, tetracosanoic acid, nonacosane, stigmast-4-en-3-one, hexacosanoic acid, tocopherols, and octacosanoic acid.

\subsubsection{Trace Elements}

$\mathrm{CMC}$ contains various trace elements, including $\mathrm{Cu}, \mathrm{Fe}, \mathrm{Zn}, \mathrm{Mn}, \mathrm{Sr}, \mathrm{Ca}$, and $\mathrm{Mg}$. Among these elements, the concentration of Fe can be as high as $136.69 \mathrm{mg} / \mathrm{kg}$, followed by $\mathrm{Zn}$ and Cu at $51.72 \mathrm{mg} / \mathrm{kg}$ and $33.49 \mathrm{mg} / \mathrm{kg}$, respectively [35].

\subsubsection{Other Compounds}

In addition to the above categories, there are other compounds such as $\beta$-sitosterol, $p$-coumaric acid, etc. and a few benzofuran compounds such as palmitic acid, sitosterol, $p$-coumaric acid, thymine, hypoxanthine, uracil, L-(+)-valine, D-phenylalanine, cnideoside A, and cnideoside B.

In sum, all the chemical constituents isolated from the herb are summarized in Table S1. Compared to the previous review [1], 80 more chemical compounds have been identified in the current review and 56 of them with their chemical structures have been reported in Table 1. 


\subsection{Pharmacology}

\subsubsection{Nervous System and Mental Illness}

Memory Loss and Neuron Degeneration

The main early symptom of Alzheimer's disease (AD) is learning deterioration and memory loss. The animal experiments have indicated that osthole could significantly enhance the synaptic transmission function of rat hippocampal dentate gyrus in a dose-dependent manner at different dosages of 5, 15 and $30 \mathrm{ng}$. Therefore, osthole could improve learning and memory ability [36]. Another study showed osthole $(40 \mathrm{mg} / \mathrm{kg})$ remarkably improved memory acquisition and consolidation of obstacles and direction to identify obstacles, and prolonged the time from decapitation to hypoxia, but had no significant improvement in memory reproduction disorders. The mechanism could be attributed to inhibition of mRNA expression of inflammation-related genes such as Tnf- $\alpha$, II- $1 \beta$, Nos2, and COX-2 in rat hippocampus [37]. Another study revealed that osthole $(40 \mathrm{mg} / \mathrm{kg})$ could suppress NF- $\mathrm{kB}$ activation, and reduce the protein expression of IL-1 $\beta$, and TNF- $\alpha$ [38]. Osthole may attenuate spatial learning and memory loss and neuronal ultrastructure injury induced by $\beta$-amyloid protein fragment 25-35 (A $\left.\beta_{25-35}\right)$. In terms of the neuronal ultrastructure injury alleviation, osthole displayed a similar effect as donepezil which is the first-line medication for AD management [39]. It had also been found that osthole $(12.5 \mathrm{mg} / \mathrm{kg}$ and $25 \mathrm{mg} / \mathrm{kg})$ regulated the expression of apoptosis-related proteins $\mathrm{Bcl}-2$ and Bax in hippocampus of $\mathrm{AD}$ rats, increased the ratio of Bcl-2/Bax, and had anti-apoptotic and protective effects on the hippocampal neurons, which may have a role in improving learning and memory impairment. The Bcl-2 gene family is an important apoptosis-regulating gene. The family has many members, among which Bcl-2, Bcl-xl, and Bcl-w have anti-apoptotic effects, and Bax, Bak, and Bok have apoptosis-promoting effects. The mechanism of apoptosis is related to the protein expression of apoptotic genes. Bcl-2 and Bax proteins are a pair of antagonistic proteins, apoptosis is accelerated by redundant Bax while apoptosis is inhibited by excessive Bcl-2 protein [40]. Osthole may also take a counter-AD effect by inhibiting cyclic nucleotide phosphodiesterases (PDEs) which are responsible for the degradation of cAMP and cGMP [41]. Furthermore, the PDE4 and PDE5 inhibition was the key to an anti-neurotoxicity effect caused by A $\beta 25-35$ with Osthole at $40 \mathrm{mg} / \mathrm{kg}$ [42]. From in vitro studies, it is also found that osthole $(50 \mu \mathrm{mol} / \mathrm{L}$ and $100 \mu \mathrm{mol} / \mathrm{L})$ promoted the proliferation of neural stem cells cultured in vitro and its mechanism could be associated with the activation of Notch 1 gene and Hes 1 gene in Notch signaling pathway by increasing the expression of Notch 1 gene and Hes 1 gene [43]. Another in vitro experiment demonstrated that the protective effect of osthole on astrocytes was related to its concentration. The low concentration $(0.1 \mu \mathrm{mol} / \mathrm{L}$ and $0.5 \mu \mathrm{mol} / \mathrm{L})$ of osthole had a better protective effect on astrocytes. The mechanism is that osthole inhibits $A \beta$-induced $\operatorname{I} \kappa \mathrm{B} \alpha$ hyperphosphorylation and attenuates NF- $\mathrm{kB}$ over-activated expression in astrocytes to exert a protective effect and improve neuronal cells' ability to resist $\mathrm{A} \beta_{25-35}$ [44]. Another study demonstrated that osthole (50 $\left.\mu \mathrm{mol} / \mathrm{L}\right)$ had the best protective effect on SH-SY5Y cells transfected with APP595/596 gene by inhibiting the mRNA and protein expression of BACE1 [45]. Osthole $(50 \mu \mathrm{mol} / \mathrm{L})$ could inhibit CAMKK2/AMPK signal pathway to reverse the neuronal synapse structure lesion induced by $A \beta[46]$. Osthole $(100 \mu \mathrm{mol} / \mathrm{L})$ exerted anti-apoptotic/pro-proliferative effects by activating $\mathrm{Wnt} / \beta$-catenin signaling and stimulating neural stem cell [47]. Osthole $(100 \mu \mathrm{M})$ increased bone marrow-derived-neural stem cell viability and decrease apoptosis on $\mathrm{H}_{2} \mathrm{O}_{2}$ induced oxidative injury. It also regulated the expression of apoptotic genes and prevented bone marrow-derived-neural stem cells apoptosis mediated by $\mathrm{H}_{2} \mathrm{O}_{2}$ through modulation of PI3K/Akt-1 signaling pathway [48]. Osthole (50 $\mu \mathrm{mol} / \mathrm{L}$ and $100 \mu \mathrm{mol} / \mathrm{L})$ had also been proven to take neural protective effect by underlining mechanisms, enhancing neural stem cell survival via the miR-9 signaling pathway, and promoting the differentiation of neural stem cells into neurons by upregulating miR-9 [49]. Osthole $(100 \mu \mathrm{mol} / \mathrm{L})$ could downregulate the expression of neuro stem cells p16, and upregulate the expression of CDKD1 and PRB protein in the result of neuro stem cells proliferation and differentiation [50]. 


\section{Brain Hemorrhage}

Osthole (15 mg/kg) enhanced superoxide dismutase level in brain tissue and dipped interleukin-8 level in serum to exerting protective effects on swelling brain tissue via in vivo study [51].

\section{Epilepsy}

From an in vivo study, osthole $(50 \mathrm{mg} / \mathrm{kg}$ ) protected hippocampal neurons in kainite by inhibiting the activity of caspase-3 and caspase-9 protein [52]. Another possible mechanism was to downregulate the expression of Puma protein in hippocampal neurons [53]. Osthole $(50 \mathrm{mg} / \mathrm{kg})$ protected neurons in the hippocampus of epileptic rats via augmenting the expression of Kv1.2 in hippocampus $\mathrm{CA}_{3}$ neurons [54]. From the in vitro study, osthole $(10 \mathrm{mmol} / \mathrm{L})$ also protected HT22 cells from glutamate excitotoxicity via the activation of the PI3K/Akt signaling pathway [55].

\section{Hypnosis and Sedation}

In in vivo studies, different concentrations of CMC extract $(62.5 \mathrm{mg} / \mathrm{kg}), 50 \%$ to $95 \%$ alcohol extract could exert hypnotic and sedative activity. Specifically, 50\% alcohol extract could exert an utmost sedative effect, while $95 \%$ alcohol extract could exert an utmost hypnotic effect [56]. The incubation period of each group of Cnidium was not significantly different from that of diazepam, which could induce sleep rapidly and significantly prolong the duration of sleep, and the hangover response and tolerance in adverse reactions were weaker than that of diazepam [57]. Another study showed the hypnotic active component of CMC (130-520 mg/kg) exerted a hypnotic effect on animal models but had no influence on the animals' learning and memory functions [58]. For hypnotic activity alone, the chemical ingredients (from CMC $(25,50$, and $100 \mathrm{mg} / \mathrm{kg}$ )) which include total coumarin, osthole, imperatorin, isopimpinellin, and bergapten can boost the expression of Cry1, Per1, and Per2 gene via inhibiting the hypnosis of hippocampal clock and Bmall gene expression. It achieved the hypnotic effect by increasing the expression of the inhibitory neurotransmitter $\gamma$-aminobutyric acid and decreasing the expression of excitatory neurotransmitter glutamic acid [59]. After osthole intervention $(25 \mathrm{mg} / \mathrm{kg}$ per day for 7 days), the malondialdehyde levels in both hippocampus tissue and serum were decreased. Additionally, the superoxide dismutase activity in the hippocampus became normal [60]. The hypnotic efficacy, spatial cognition and spatial reference memory preservation function by CMC (40, 80, and $160 \mathrm{mg} / \mathrm{kg}$ ) have been verified in another study with a mouse model [61].

\section{Anxiety}

Osthole (1.75-14 mg/kg) was found to have an anxiolytic effect in an in vivo study by suppressing anxious behavior after irritation [62].

\subsubsection{Immune System}

\section{Allergy}

From in vivo studies, for anti-asthmatic activity, osthole $(25,50,100 \mathrm{mg} / \mathrm{kg}) \mathrm{kept}$ the airway inflammation at bay, the production of Th2 cytokines and OVA-specific IgE, the recruitment of eosinophils and mucus overproduction [63]. Osthole $(10 \mathrm{mg} / \mathrm{kg}$ and $50 \mathrm{mg} / \mathrm{kg})$ improved goblet cell proliferation and reduced fibrosis in lung tissue and mucus secretion. Besides, it is also found that osthole could interfere with the production of white blood cells and eosinophils [64]. Osthole (10 and $40 \mathrm{mg} / \mathrm{kg}$ ) reduced airway mucus secretion by downregulating mCLCA3, mRNA and MUC5AC protein levels, and suppressing IL-4 induced eotaxin in BEAS-2B cells through inhibition of STAT6 expression $[65,66]$. Osthole $(200$ and $500 \mathrm{mg} / \mathrm{kg}$ ) exhibited an inhibitory effect for contact dermatitis rat model especially for the symptom of ear swelling [67]. From in vitro studies, osthole (150, 300, $450 \mathrm{ng} / \mathrm{mL}$ ) acted as a natural histamine antagonist that targeted TNF- $\alpha$, IL- 6 and IL-10 cytokine secretion levels without a toxic effect for peripheral blood mononuclear cell. Thereby, this phenomenon 
could be the evidence for the beneficial role of osthole in allergic conditions [68]. For allergic skin diseases, osthole $(0.25,0.5,1 \mathrm{~g} / \mathrm{mL})$ exerted the anti-allergic effect via inhibiting the inflow of $\mathrm{Ca}^{2+}$ channel in mast cell and reducing the release of histamine [69]. Osthole affected peripheral blood mononuclear cells' cytokine secretion to the same extent as the anti-histamine medication, fexofenadine. Specifically, osthole $(150 \mathrm{ng} / \mathrm{mL})$ was more effective than fexofenadine in terms of IL-13 blocking ability. The blockage effect on other cytokines such as IL-1 $\beta$, IL-10, and TNF- $\alpha$ was similar to fexofenadine [70]. The extract of CMC $(100 \mu \mathrm{g} / \mathrm{mL})$ had immune regulatory functions by inhibiting retinoic acid receptor $\alpha$ reporter gene transcription which could affect the immune cell production and ratios [71].

\subsubsection{Circulatory System}

\section{Atherosclerosis}

Through in vivo studies, osthole (10 mg/kg, and $30 \mathrm{mg} / \mathrm{kg}$ for 16 days) downregulated NF- $\mathrm{KB}$ and TLR4 expression to reduce inflammatory factors such as TNF- $\alpha$ and IL-1 $\beta$, and restrained intimal hyperplasia and vascular smooth muscle cell proliferation [72,73]. It is observed that when the estradiol 2 level in serum was in a certain amount, osthole $(10-20 \mathrm{mg} / \mathrm{kg}$ and $10 \mathrm{mg} / \mathrm{kg})$ treated hyperlipidemia and an ovariectomized model could exhibit lower levels of lipoprotein lipase, hepatic lipase, very low-density lipoprotein, chylomicron, and triglyceride [74]. From in vitro studies, osthole $(20,40 \mu \mathrm{mol} / \mathrm{L})$ suppressed the apoptosis of human umbilical vein endothelial cells with the mechanism of activating Akt/Enos/NO signal pathway and inhibited atherosclerotic formation by regulating lipid and countering inflammation [75].

\section{Cardiac Diseases}

Through docking analysis and chromatographic retention time measurements, imperatorin exerted the same effect as verapamil which is a calcium antagonist for hypertension and cardiovascular disease management [76]. From in vivo studies, total coumarins as a family of compounds remarkably reduced the area of myocardial infarction and enhance the cardiac function after the infarction. Meanwhile, at $20 \mathrm{mg} / \mathrm{kg}$ it also decreased the number of mitochondrial fragments and improved the expression of dynamin-related peptide-1 and optic atrophy-1 which were associated with mitochondrial morphology [77]. Another study indicated that osthole $(50 \mathrm{mg} / \mathrm{kg})$ could protect myocardial ischemia-reperfusion injury from mitochondrial mediating apoptosis via suppressing the activation of Wnt/-catenin/p53 signal pathway [78]. Osthole $(25 \mathrm{mg} / \mathrm{kg})$ exerted a similar effect by taking antiapoptotic effects via PI3K/AKT signaling pathway [79]. It $(25 \mathrm{mg} / \mathrm{kg})$ also resisted myocardial apoptosis by upregulating the expression of Bcl-2 protein and downregulating the expression of Bax protein, therefore to increase the ratio of Bcl2/Bax [80]. For right ventricle remodeling, osthole (10 and $20 \mathrm{mg} / \mathrm{kg}$ ) adjusted the right ventricle remodeling induced by monocrotaline. The mechanism could be associated with the up-regulation of the expression of peroxisome proliferator-activated receptor $\alpha$ and peroxisome proliferator-activated receptor $\gamma$ [81]. Pulmonary artery remodeling could also be reversed by osthole at $(10$ and $20 \mathrm{mg} / \mathrm{kg}$ ) via augment expression of p53 and lessen the expression of proliferating cell nuclear antigen and Ki67 [82]. From in vitro studies, for anti-arrhythmia activity, osthole with a concentration from 100-500 $\mu \mathrm{mol} / \mathrm{L}$ could dramatically inhibit sodium current of ventricular myocytes in the animal model [83]. Osthole ( $\mathrm{IC}_{50}=162.156 .2$ and $300 \mu \mathrm{mol} / \mathrm{L}$ ) could also inhibit L-type (Cav1.2 and Cav1.3) and N-type (Cav2.2) calcium channels to restrain the calcium current, therefore to shorten the duration of cardiac cell potential [84]. Osthole could inhibit the potassium channels to attenuate the electric current of cardiocytes. Specifically, the outward potassium channel could be reversed when the $\mathrm{IC}_{50}$ is around $101.1 \mu \mathrm{mol} / \mathrm{L}$, the inward potassium channel can be influenced when the concentration reaches $200 \mu \mathrm{mol} / \mathrm{L}$ [85]. Osthole $\left(10^{-9}-10^{-5} \mathrm{~mol} / \mathrm{L}\right)$ not only dilated the artery ring of normal human and rat lung tissue but also dilated the pulmonary arteries on both species. The mechanism could be related to either calcium release from the sarcoplasmic reticulum or ion channel [86]. Osthole $(5 \mu \mathrm{g} / \mathrm{mL})$ managed myocardial fibrosis by inhibiting collagen I and II expression and diminished their 
ratio via the transforming growth factor- $\beta$ (TGF- $\beta$ )/Smad signaling pathway in TGF- $\beta 1$ overexpressed cardiac fibroblasts (CFs) [76].

\section{Hypertension}

Imperatorin, xanthotoxol, and other imperatorin derivatives can relax the mesenteric artery, basilar artery, and renal artery. It is also found that two derivatives showed the promising results as a vasodilator agent for the mesenteric artery. They are 9-(2-(diisopropylamino) ethoxy)-7H-furo[3,2-g] chromen-7-one and 9-(2-(pyrrolidin-1-yl) ethoxy)-7H-furo[3,2-g] chromen-7-one. Another pair of derivatives have shown the potential to be a vasodilator agent for basilar artery [87]. From in vivo studies, Imperatorin $(25 \mathrm{mg} / \mathrm{kg})$ exerted influences directly on the cardiac muscle. In detail, imperatorin inhibited cardiac myocyte protein synthesis induced by angiotensin II, it also attenuated pathological myocardial hypertrophy and pathological cardiac fibrosis. Besides these, it prevented the transition to heart failure [88]. Osthole inhibited the elevation of systolic blood pressure in stroke-prone spontaneously hypertensive rats. It also induced a remarkable increase in hepatic 3-hydroxy-3-methylglutaryl coenzyme A reductase mRNA expression induced the cholesterol decreased in the liver [89]. For imperatorin, after 10 weeks of intervention $(6.25,12.5$, and $25 \mathrm{mg} / \mathrm{kg}$ per day), the middle and high dose group demonstrated a significant reduction of mean blood pressure on renal induced hypertension rat models. Besides, the kidney function parameters were attenuated by these two dose groups. Specifically, there was a decreasing trend in both angiotensin II levels and plasma endothelin levels while an increasing trend occurred in plasma nitric oxide synthase (NOS) activity and nitric oxide (NO) levels. Imperatorin could also reduce renal excretion of 8-iso-prostaglandin F2 $\alpha$ in renal induced hypertension rat models with no proteinuria increase detection. Xanthine oxidase as a major supply of renal reactive oxygen species was remarkedly decreased after the imperatorin intervention. As for mRNA expression reductions had been noticed which includes p22phox, p67phox, p47phox, and gp91phox, the protein levels of gp91phox and p47phox were diminished in renal cortical tissue [90]. It is also found that imperatorin $(6.25,12.5$, and $25 \mathrm{mg} / \mathrm{kg})$ could relax aortic rings. For calmodulins' interactions in molecular docking, imperatorin had the same binding site as verapamil (a commonly used hypotensive medication) [91]. As tested by both in vitro studies, Imperatorin $(1-100 \mu \mathrm{m})$ could restrict angiotensin II-induced cardiac myocyte protein production, modulate pathological myocardial hypertrophy, pathological cardiac fibrosis, and prevent heart failure [92]. Osthole $(1-100 \mu \mathrm{mol} / \mathrm{L})$ triggered an endothelium-independent relaxation in mice aortic rings via blocking $\mathrm{Ca}^{2+}$ channel to achieve a vasorelaxation effect [93].

\section{Organ Ischemia}

For renal ischemia protection, osthole $(40 \mathrm{mg} / \mathrm{kg})$ could lower several biomarkers, including creatinine and blood urea nitrogen, and it was observed via histological evidence that renal tubular dilatation, luminal obstruction, necrosis, shedding, and renal interstitial inflammatory cell infiltration were markedly reduced. It was also found that osthole reduced the production of reactive oxygen species which could induce the injury on mitochondrial when its production and metabolism were imbalanced. Osthole enhanced the ATPase activity in mitochondrial. It also suppressed the activation of the apoptotic signal pathway and the expression of apoptosis-related proteins and inhibited the expression of cytochrome C [94]. In another study, osthole played an important role in inflammation and oxidative stress during the progression of renal ischemic injury. In details, osthole reduced the expression of proinflammatory cells such as tumor necrosis factor- $\alpha$, monocyte chemotactic protein- 1 , and interleukin 6 (IL-6) mRNA at a dosage of $20 \mathrm{mg} / \mathrm{kg}$. Osthole also dramatically lowered the expression of oxidative stress enzyme, malondialdehyde. In addition, it could enhance the bioactivity of catalase, glutathione peroxidase, and superoxide dismutase which is the enzyme against oxidative stress $[95,96]$. Osthole $(20,40$, and $80 \mathrm{mg} / \mathrm{kg}$ ) exerted similar effects on other organs such as retina and intestinal. Taking the retina as an example, in addition to the above mechanisms, osthole could elevate the amplitude of electron retinol graph-b [97]. For intestinal ischemia-reperfusion lung injury model, osthole ( 5 and $25 \mathrm{mg} / \mathrm{kg}$ ) could significantly improve the lesions of lung tissue induced by 
oxidative stress and apoptosis and also induce the reduction of Caspase-3 expression [98]. In $50 \mathrm{mg} / \mathrm{kg}$ osthole intervention group, the survival rate was impressive, as high as $85 \%$, and the oxygenation and mean arterial pressure was also improved in both $10 \mathrm{mg} / \mathrm{kg}$ and $50 \mathrm{mg} / \mathrm{kg}$ group, the pathologic examination revealed the improvement in lung injury in both dosage groups, reactive oxygen species, lung wet-to-dry weight ratio, pulmonary permeability index was dramatically decreased in both dosage groups, the malondialdehyde level was decreased while superoxide dismutase activity was increased in both dosage groups, inflammatory cytokine levels such as IL- 6 and TNF- $\alpha$ were reduced in both dosage groups, myeloperoxidase as a neutrophil indicator enzyme was lowered by osthole in both dosage groups [99]. In the heart transplant-induced injury model, the biomarkers of heart function including lactate dehydrogenase, cardiac creatine kinase, and creatine kinase-muscle/brain were down-regulated by osthole at $25 \mathrm{mg} / \mathrm{kg}$. For the microstructure of myocardium after osthole intervention, the sarcoplasmic reticulum was slightly dilated, the myofilament was dissolved, the nuclear membrane was intact, the mitochondria were swollen, but the morphology was not severely disordered and vacuolar degeneration was rare, without dissolution [100]. For cerebral ischemia, osthole exerted an anti-cerebral ischemia effect by suppressing mitochondria-mediated apoptosis via taking below actions. It improved the neurological symptoms and brain swelling at best dosage of $100 \mathrm{mg} / \mathrm{kg}$, inhibited reactive oxygen species (ROS) production, enhanced the membrane potential and the adenosine triphosphate (ATP) vitality of mitochondrial, suppressed apoptosis-inducing factor and cytochrome C migration, attenuated apoptosis-related signal pathways. Specifically, upregulated caspase 3, caspase 9 and Bcl-2/Bax protein expression, downregulated cleavage-caspase 3 and cleavage-caspase 9 protein expression. Thus, osthole's anti-cerebral ischemia effect could be associated with ROS and ATP level drop, the membrane potential stability during the perfusion period of mitochondrial, and mitochondrial membrane permeability transition pore from opening [101]. It is noted that osthole $(4,8$, and $16 \mathrm{mg} / \mathrm{kg}$ ) could elevate the level of superoxide dismutase and glutathione while decreases the level of malondialdehyde [102]. It is also found that osthole $(25,50$, and $100 \mathrm{mg} / \mathrm{kg})$ could impede cerebral infarction, hippocampus neuronal lesion, and apoptosis created by middle cerebral artery occlusion/reperfusion (MCAO/R) model via initiating Notch 1 signaling pathway in a dose-dependent manner in vivo. The similar findings were obtained by the oxygen-glucose deficiency/reperfusion (OGD/R) model intervened by primary neurons in vitro [103]. When it comes to the protein expression, matrix metalloproteinase-9 (MMP-9) was detected to be downregulated in ischemia/reperfused brain with osthole at $100 \mathrm{mg} / \mathrm{kg}$ [104]. The learning and memory impairment were ameliorated by osthole (12.5 and $25 \mathrm{mg} / \mathrm{kg}$ ) after cerebral ischemia-reperfusion injury. Osthole lifted hippocampal long-term potentiation level in the model rats via attenuating glutamic acid and $\gamma$-aminobutyric acid levels [105]. By inhibiting IL- 8 and IL-1 $\beta$, the vitality of myeloperoxidase could be impeded, reducing the infiltration of neutrophils in brain tissue and local tissue inflammation, enhancing $\mathrm{Na}^{+}, \mathrm{k}^{+}$-ATPase, $\mathrm{Ca}^{2+}$-ATPase activity. To alleviate nitric oxide (NO) induced injury to neuron, osthole (5 and $10 \mathrm{mg} / \mathrm{kg}$ ) inhibited inducible nitric oxide synthase (iNOS) vitality and NO level [106,107].

Thrombosis

From in vivo study, osthole (10, 20, and $40 \mathrm{mg} / \mathrm{kg}$ ) exhibited a remarkable anti-clot effect on the venous and artery-vein bypass of rats. The mechanism could be attributed to NO and 6-keto-prostaglandin $1 \alpha$ (6-Keto-PGF1 $\alpha$ ) level augment thromboxane B2 (TXB2) level decrease and TXB2/6-Keto-PGF1 $\alpha$ ratio [108]. For the in vitro study, osthole $(0.95-3.78 \mathrm{mg} / \mathrm{mL})$ inhibited the rising calcium concentration in platelet induced by thrombin by restraining the expression of Inositol triphosphate receptor-3 [109].

\subsubsection{Symptoms and States of Undefined Origin}

Pain

Post-surgery administration of osthole $(50 \mu \mathrm{L})$ in an early stage can mitigate the nucleus pulposus-induced radicular inflammatory pain via inhibiting the expression of phosphorylation 
extracellular signal-regulated kinase and cyclooxygenase-2 mRNA in the spinal dorsal horn and nitric oxide synthase in dorsal root ganglion $[110,111]$. In another study, osthole $(50 \mu \mathrm{L})$ could upregulate calcitonin gene-related peptide receptors 1 (CGRPR1) to easing sciatica pain by downregulating CGRPR1 protein expression [112]. From in vitro studies, osthole $(0.2,0.5$, and $1 \mathrm{~g} / \mathrm{mL})$ could block the conduction of the action potential of nerve in pain signal transduction [113]. Osthole (20 and $50 \mathrm{~g} / \mathrm{L})$ could also inhibit the acid-stimulated change of dorsal root ganglion neuron's membrane potential of rats with nucleus pulposus-induced hyperalgesia [114].

\section{Hepatic Steatosis}

Osthole $(10,20$, and $40 \mathrm{mg} / \mathrm{kg}$ ) reduced hepatic oxidative stress in the treatment of alcoholic fatty liver with $20 \mathrm{mg} / \mathrm{kg}$ providing the best outcome [115]. Osthole (10, 20, and $40 \mathrm{mg} / \mathrm{kg}$ ) was effective against fatty liver by suppressing hepatic sterol regulatory element-binding protein-1c/2 mRNA expressions and modulating the sterol regulatory element-binding protein-1c/2-mediated target gene expression such as fatty acid synthase, cholesterol $7 \alpha$-hydroxylase, and low-density lipoprotein [116]. Osthole $(10,20$, and $40 \mathrm{mg} / \mathrm{kg}$ ) reduced the accumulation of lipids in the liver in the mechanism of antioxidation and TNF- $\alpha$ production suppression [117]. From in vitro studies, osthole $(100 \mu \mathrm{mol} / \mathrm{L}$ and $25-200 \mathrm{mg} / \mathrm{mL}$ ) could reduce triglycerides and free fatty acid in hepatocytes with the mechanism of peroxisome proliferator-activated receptor activation, sterol regulatory element-binding protein-1/2 reduction, fatty acid synthase, and diacylglycerol acyltransferase gene expressions and increment of carnitinepalmitoyl transferase, fatty acid synthase 4 , liver fatty acid, cholesterol $7 \alpha$-hydroxylase, and 3-hydroxy-3-methylglutaryl-CoA binding protein gene expressions [118,119].

\section{Inflammation}

From in vivo studies, osthole $(50 \mathrm{mg} / \mathrm{kg})$ could benefit inflammatory bowel disease by increasing IL-10 and reducing the levels of TNF- $\alpha$ and IL-17. When it came to the combination with sulfasalazine, the results showed a significant reduction in the levels of TNF- $\alpha$, IL-17, and IFN- $\gamma$, meanwhile, it was also found a remarkable increase of IL-4 and IL-10. Thus, osthole could reverse the polarized balance of Th1, Th2, and Th17 cells by reduction of proinflammatory cytokines and increase of anti-inflammatory cytokines [120]. Inflammation played an important role in the brain injury model. Osthole $(10,20$, and $30 \mathrm{mg} / \mathrm{kg}$ ) could restrain the expressions of inflammatory factors and decrease the apoptosis of neurons [121]. Specifically, osthole could lower the ratio of Bax/Bcl-2 and the expression of caspase- $3 \mathrm{mRNA}$ at the dosage of 20 and $30 \mathrm{mg} / \mathrm{kg}$. Therefore, it could achieve inhibition for nerve cell apoptosis caused by brain injury. It could also reduce the positive cells of caspase- 3 when the dosage is at $30 \mathrm{mg} / \mathrm{kg}$ [122]. Cnidium lactone micro-emulsion $(2,4$, and $8 \mathrm{mg} / \mathrm{mL})$ for local external application remarkably reduced auricular swelling induced by xylene and vola pedis swelling induced by egg white [123]. Peroxyauraptenol and auraptenol as chemical compounds of CMC could exert an anti-inflammatory effect. Peroxyauraptenol was 10 times stronger than auraptenol in terms of the inhibition of IL- 6 secretion and NO production. For iNOS and pro IL- $1 \beta$ expression inhibition, peroxyauraptenol was also more efficient than auraptenol. For peroxyauraptenol alone $(10 \mu \mathrm{M})$, it could also lower the phosphorylation levels of mitogen-activated protein kinases and PKC- $\alpha / \delta$, reduce NLRP3 inflammasome activation by mitigating mitochondrial damage, inhibit IL-1 $\beta$ precursor expression [124]. It was observed in animal experiments that osthole was associated with the inflammatory responses which included inflammatory cell infiltration, erythrocyte exudation and capillary congestion. It $(40 \mathrm{mg} / \mathrm{kg})$ inhibited the classic signal pathway of JAK2/STAT3 and expression of inflammatory cytokines such as IL-6, IL-1 $\beta$, and TNF- $\alpha$ [125]. Osthole (100 and $200 \mathrm{mg} / \mathrm{kg}$ ) demonstrated protective effects for sepsis-induced acute lung lesions via suppressing the inflammatory reaction, oxidative stress, and cell apoptosis [126]. From in vitro studies, osthole (4, 7 and $10 \mu \mathrm{g} / \mathrm{mL})$ could shield inflammatory BV2 cells from inflammation-induced by lipopolysaccharide stimulation in the mechanism of inhibition of NF-KB and Nrf2 signaling pathways [127]. Osthole (12.5-100 $\mu \mathrm{mol} / \mathrm{L})$ could dramatically suppress the production of NO, IL- 6 and TNF- $\alpha$ and other inflammatory cytokines. 
Moreover, it also inhibited the protein expression of iNOS and COX-2 [128]. The reason behind osthole's $(10 \mu \mathrm{g} / \mathrm{mL})$ suppression of TNF- $\alpha$, NO and COX-2 expression could be partially attributed to inhibition of PKC- $\alpha, P K C-\varepsilon, J N K 1 / 2, p 38, R O S$, and NF- $\kappa B$ pathways [129]. Osthole $\left(\mathrm{IC}_{50}\right.$ value of $0.005 \mu \mathrm{g} / \mathrm{mL}$ ) and cnidimol A ( $\mathrm{IC}_{50}$ value of $3.2 \mu \mathrm{g} / \mathrm{mL}$ ) could be used as promising candidates against formyl-L-methionyl-L-leucyl-L-phenylalanine-induced $\mathrm{O}_{2}$ generation and elastase release for the management of multiple inflammatory diseases [130].

Fatigue

Through in vivo studies, for fatigue management, the traditional Japanese formula "Zena F-III" $(10 \mathrm{~mL} / \mathrm{kg}$ ) which contains CMC and other 14 herbs had been vindicated to be able to block the calcium to take its therapeutic effect. The target chemical compound in this study was Osthole [131]. In another study, CMC (0.75-4.5 g/kg per day for 3 days) could mitigate the repercussions of high-intensity exercise on serum testosterone by maintaining it at normal physiological levels. It could also increase hemoglobin and glycogen reserves and promote protein synthesis and inhibit the degradation of amino acid and protein [132].

Oxidation

From an in vitro study, for antioxidant effect, osthole $(0.1-0.6 \mathrm{~mL})$ had scavenging capability against three types of free radicals, including $\mathrm{O}_{2}{ }^{-}, \mathrm{OH}$ and 1,1-diphenyl-2-picrylhydrazyl-based radical [133].

\subsubsection{Other Infectious and Parasitic Diseases}

\section{Bacterial Infectious Disease}

The in vitro experiments showed the extract of CMC could significantly inhibit Escherichia coli in a dosage-dependent manner. The minimal inhibitory concentration was $250 \mathrm{mg} / \mathrm{mL}$, and the minimum bactericidal concentration was $500 \mathrm{mg} / \mathrm{mL}$ [134]. Osthole $\left(\mathrm{IC}_{50}=34 \mu \mathrm{M}\right)$ and imperatorin $\left(\mathrm{IC}_{50}=\right.$ $28 \mu \mathrm{M}$ ) could inhibit Staphylococcus aureus. Osthole demonstrated 4-fold inhibition in the minimal inhibitory concentration of ciprofloxacin which is one of the frontline anti-bacteria medications [135]. CMC extract inhibited urea plasma urealyticum, and the minimal inhibitory concentration ranged from 62.5 to $125 \mu \mathrm{g}$ [136]. The combinations of matrine or oxymatrine with CMC $(60 \mathrm{mg} / \mathrm{mL})$ took their synergistic inhibitory effect against individual microorganisms such as Candida albicans, Staphylococcus aureus, and Escherichia coli [137]. The co-extracted volatile oil $(100 \mu \mathrm{L})$ formed by both CMC $(5 \mathrm{~g} / \mathrm{mL})$ and Zanthoxylum bungeanum $(5 \mathrm{~g} / \mathrm{mL})$ showed a better anti-vaginitis effect than a single application which indicated the synergistic effect of these herbs [138]. Both in vivo and in vitro studies showed CMC (300 mg/kg per day for 5 days) enhanced macrophage phagocytosis, increased the survival rate on mice after Escherichia coli infection and protected the host from infection via improving bacterial reproduction in the peripheral blood. Besides, the inflammatory cytokines had gone through significant changes on Raw 264.7 cells after CMC intervention (10, 30, and $100 \mu \mathrm{g} / \mathrm{mL})$. IL-12, IFN- $\gamma$, and TNF- $\alpha$ levels in the serum dramatically increased while IL-6 level remarkedly decreased [139].

Virual Infectious Disease

Osthole had anti-HIV activity by inhibiting the export of viral regulatory protein, viral regulatory protein from the nucleus to the cytoplasm with $\mathrm{IC}_{50}$ value at $1.6 \mu \mathrm{m}$ [140].

Fungal Infectious Disease

From in vitro studies, CMC inhibited intestinal Candida species like C. albicans, C. krusei, and C. tropicalis at an average minimum inhibitory concentration of $12.5 \mathrm{~g} / \mathrm{L}$ [141]. Osthole $(4-16 \mu \mathrm{g} / \mathrm{mL})$ had a remarkable synergistic effect with fluconazole against fluconazole-resistant $C$. albicans. The possible mechanism could be related to endogenous reactive oxygen species augmentation [142]. Xanthotoxin as a common methoxylated furanocoumarin had been reported to inhibiting the human fungi Candida albicans and Cryptococcus laurentii [143]. Osthole $(0.5 \mathrm{~g})$ with the integrated lactonic ring had the anti-fungal activity 
to all three tested funguses including T. mentagrophytes, T. purpureatum, and Microsporum gypseum. When the lactonic ring was broken, the antifungal effect did not exist on T. mentagrophytes [144].

\section{Parasitic Disease}

From in vitro studies, osthole $(120 \mu \mathrm{m})$ inhibited the formation of blood vessels against echinococcosis without the high risk of liver and kidney toxicity [145]. In another study, osthole $(10 \mathrm{mg} / \mathrm{mL})$ impaired the ultrastructure of Giardia lamblia against its infection. Specifically, the impaired suction membrane led to the unstable suction and malnutrition for Giardia lamblia [146]. Imperatorin $\left(\mathrm{LD}_{50}=3.14 \mathrm{mg} / \mathrm{L}\right)$ and osthole $\left(\mathrm{LD}_{50}=13.11 \mathrm{mg} / \mathrm{L}\right)$ could be utilized as larvicides in the management of mosquito populations, especially to target insecticide-resistant mosquito larvae [147]. Osthole $(1.12,2.24$, and $4.48 \mathrm{mg} / \mathrm{mL})$ could eliminate Trichomonas vaginalis with a minimal concentration of $1.12 \mathrm{mg} / \mathrm{mL}$ in the tube [148]. With $120 \mu \mathrm{M}$, the inhibition effect of osthole was so strong on E. granulosus protoscoleces that all the protoscoleces were eliminated within three days. In an in vivo study, osthole could shrink the size of metacestodes-infected mice tissue by remarkably reducing the small vesicles and blood vessels. It was also noted that the level of IL-4 and the percentage of eosinophils had been increased in the osthole-treated group. For addressing cytotoxic concerns, there were no adverse changes detected from morphological observation and liver and kidney function indexes [145]. For another kind of parasite, Giardia lamblia, osthole may inflict a series of structure alterations which included cell membrane damage, nuclear deformity, and sucking structure damage. Therefore, it is reasonable to deduce that all these structure alterations induced abnormal physiological functions including unstable sucking and deteriorating nutrition absorption, which led to autophagy and death [146]. The most efficient concentration was $5.0 \mathrm{mg} / \mathrm{mL}$ in the study which could approximately reduce the number of the parasite down to $21.38 \%$ with $\mathrm{IC}_{50}$ was $1.345 \mathrm{mg} / \mathrm{mL}$, it also deactivated the vitality of the parasite down to less than $50 \%$ after $5 \mathrm{~h}$ intervention [149]. For Trichomonas vaginalis, it was observed that, after the osthole intervention, the body of the parasite was turned into a round shape, bubbles emerged inside the nucleus, the activity of flagellum and the undulating membrane was dramatically lessened and gradually ceased which led to the parasite body breakage. The active concentration started from $1.12 \mathrm{mg} / \mathrm{mL}$ which could ensure the $100 \%$ elimination of the parasite after the 24-h intervention [148].

\subsubsection{Endocrine-Metabolic System}

\section{Diabetes Mellitus}

From in vivo studies, osthole ( $20 \mathrm{mg} / \mathrm{kg}$ per day for 14 days) reduced the up-regulation of the $\mathrm{P}_{2} \mathrm{X}_{4}$ receptor, and downregulated the IL-1 $\beta$, TNF- $\alpha$, brain-derived neurotrophic factor, and p-p38MAPK and upregulated IL-10 in diabetes mellitus [150]. For diabetes-associated cognitive decline, osthole protected neuro functions via inhibiting PI3K/Akt signaling pathway with the dosage at $50 \mathrm{mg} / \mathrm{kg}$ and exerted a similar effect to the positive control medication Donepezil [151]. From in vitro studies, osthole $(5,10,20$, and $40 \mu \mathrm{mol} / \mathrm{L})$ decreased the apoptotic rate in NIT-1 cells and the expression of apoptotic proteins such as Bax and Caspase 3, increased the expression of anti-apoptotic protein Bcl-2 to achieve inhibiting cell apoptosis. The possible mechanism could be related to PPAR $\alpha$ and endoplasmic reticulum stress [152]. Osthole $(100 \mathrm{nmol} / \mathrm{L})$ protected human umbilical vein endothelial cells from the injury induced by high glucose that could benefit the prevention and control of diabetes angiopathies [153]. Osthole $(0-200 \mu \mathrm{m})$ activated glucose uptake but initiated deactivation in L929 fibroblast cells and inhibited uptake in HCLE cells [154].

\section{Hormone Modulation}

Osthole (2.5 g) and total coumarins of CMC enhanced the pituitary-thyroid axis function of the Kidney-Yang deficiency rat model by increasing the secretion and synthesis of the thyroid hormone of T3, reverse T3, and T4 [155]. For estrogen-like effects, osthole $(0.75-24 \mathrm{mg} / \mathrm{kg})$ increased the expression of uterine estrogen receptor $\beta$ and surge the level of estradiol 2 in the serum [156]. 


\subsubsection{Skin and Subcutaneous Cell Tissue}

Hypertrophic Scar Fibroblasts

From in vitro studies, osthole could inhibit the growth of hypertrophic scar fibroblasts via apoptosis and decreased the expression of TGF- $\beta_{1}$ with $\mathrm{IC}_{50}$ value $15.5+/-2.2 \mu \mathrm{mol} / \mathrm{L}$ toward hypertrophic scar fibroblasts [157]. In another study, osthole could exert its maximum inhibitory effect on mice embryonic fibroblasts which are similar to human dermal fibroblasts with a dosage at $2.5 \times 10^{4} \mathrm{~mol} / \mathrm{L}$ [158]. Osthole $(5-50 \mu \mathrm{mol} / \mathrm{L})$ significantly inhibited the growth of human hypertrophic scar fibroblasts and reduced the expression of TGF- $\beta 1$ [159].

\section{Psoriatic Effect}

From in vitro studies, osthole could induce $\mathrm{HaCaT}$ cells apoptosis in a dose-dependent manner which indicated osthole could exert anti-psoriatic effect by inhibiting excessive proliferation of epidermal cells and inducing apoptosis of epidermal cells. The $\mathrm{IC}_{50}$ was $1.75 \times 10^{-4} \mathrm{~mol} / \mathrm{L}, 1.47 \times 10^{-4}$ $\mathrm{mol} / \mathrm{L}$, and $1.35 \times 10^{-4} \mathrm{~mol} / \mathrm{L}$ for $24 \mathrm{~h}, 48 \mathrm{~h}$, and $72 \mathrm{~h}$ incubation, respectively [160]. Another study tested the $\mathrm{CMC}$ on the same cells with $\mathrm{IC}_{50} 114.6 \mu \mathrm{g} / \mathrm{mL}$ by 3-(4,5-dimethylthiazol-2-yl)-2,5-diphenyl tetrazolium bromide (MTT) assay [161].

\section{Atopic Dermatitis}

From in vivo and in vitro studies, for atopic dermatitis management, osthole $(10,20$, and $40 \mathrm{mg} / \mathrm{kg}$, 1.0 and $5.0 \mathrm{mg} / \mathrm{mL}$ ) suppressed the proliferation and degranulation of sensitized mast cells and inhibited the expression of STAT5 gene and protein [162,163]. From an in vitro study, osthole microemulsion $(2,4$, and $8 \mathrm{mg} / \mathrm{mL})$ could counter histamine phosphate and 4-aminopridine (4-AP) induced pruritis by inhibiting delayed hypersensitivity caused by dinitrochlorobenzene (DNCB) which indicated the anti-pruritic effect through anti-histamine and anti-allergic reactions [164].

Itchiness

From the in vitro study, osthole $(2,4$, and $8 \mathrm{mg} / \mathrm{mL})$ could exert a localized anesthetic effect and inhibition effect on $\mathrm{N}$ calcium channel Cav2 genus II which mainly distribute on the sensory neuron's cell body and nerve endings [164]. For therapeutic effect constituent identification, the volatile oil had the best antipruritic effect, and alcohol extract had the weakest effect [165]. From an in vivo study, osthole and isopimpinellin from CMC extract $(200$ and $500 \mathrm{mg} / \mathrm{kg}$ ) showed an inhibitory effect on compound $48 / 80$ caused scratching behavior [166].

\subsubsection{Musculature and Skeleton}

\section{Osteoporosis}

From the in vivo studies, among CMC coumarins, six (at $5 \mathrm{~g} / \mathrm{kg}$ ) have shown androgen-like effects on male rats in experiments. Specifically, osthole, imperatorin, bergapten, isopimpinellin, xanthotoxin, and xanthotoxol can increase bone formation and decrease bone resorption which counters the pathogenic effects induced by prednisone. These findings shed the light for the synergic application of both glucocorticoid and coumarin extract of CMC against osteoporosis [167]. Total coumarins $(2.5 \mathrm{~mL} / \mathrm{kg})$ could dramatically improve the bone density, increase IGF-1 and 25-OH vitamin D level [168]. For in vitro study, osthole and imperatorin $(0.1-10 \mu \mathrm{mol} / \mathrm{L})$ exerted estrogen-like effects to boost osteoblastic activity in vitro cell culture experiments [169].

As for osthole, in female rats, osthole $(6.7 \mathrm{mg} / \mathrm{kg})$ displayed an anti-osteoporosis effect on ovariectomized samples which simulated the menopause-related osteoporosis [170]. It was also revealed that osthole could increase the levels of calcium and phosphorus in serum and boost the phosphorus level in femurs. In addition, the bone density in the lumbar spine and femur showed an increasing trend, the average width and area percentage of trabecular bone were 
remarkedly elevated, the biomechanical index was attenuated by osthole. In detail, ultimate strength displayed an increasing trend and the bending section coefficient was significantly reduced [171]. Osthole $(20 \mathrm{mg} / \mathrm{kg})$ intervention significantly inhibited tricalcium phosphate-induced endoplasmic reticulum stress response and reduced glucose-regulated protein 78 and CAAT/enhancer-binding protein homologous protein expression, suggesting that osthole's inhibition of tricalcium phosphate particle-induced osteolysis around the prosthesis may be achieved by regulating endoplasmic reticulum stress response [172]. The bone morphogenetic protein was enhanced by cyclic adenosine monophosphate/cAMP response element-binding protein signaling pathway which targeted the transcription factor osterix. The expression of osterix was up-regulated by osthole at $20 \mathrm{mg} / \mathrm{kg}$ [173]. From in vitro studies, osthole $\left(1 \times 10^{-6} \mathrm{~mol} / \mathrm{L}\right.$ and $\left.1 \times 10^{-8} \mathrm{~mol} / \mathrm{L}\right)$ upregulated osteoprotegerin (OPG) mRNA expression level but did not influence on receptor activator of NF- $\mathrm{kB}$ ligand (RANKL) mRNA expression level. Finally, it affected the ratio of OPG/RANKL to inhibit bone resorption from osteoclasts [174]. Osthole promoted bone marrow stromal stem cells differentiation to osteogenesis at the dosage of $1 \times 10^{-5} \mathrm{~mol} / \mathrm{L}$, and also increased the gene expression of bFGF, OSX, Runt-related gene 2 , and IGF-1 [175]. Osthole at a concentration of $1 \times 10^{-5} \mathrm{~mol} / \mathrm{L}$ could stimulate differentiation and maturation of rat calvarial osteoblasts and exert no cytotoxic effect [175]. Osthole $(0,6.25,12.5,25$, and $50 \mu \mathrm{mol} / \mathrm{L}$ ) could inhibit the expression of proliferating cell nuclear antigen and cyclin D1 to achieve chondrocytes inhibition in a dose-dependent manner [176]. Osthole has poor water solubility, low bioavailability, and poor infiltration for bone tissue, therefore osthole could promote osteoblasts by applying a water-soluble chitosan derivative as a carrier to boost the efficacy [177]. The Wnt/ $\beta$-catenin signaling pathway could be one of the mechanisms [178]. It was also found that the expression level of tartrate-resistant acid phosphatase, macrophage colony-stimulating factor, and cathepsin $\mathrm{K}$ mRNA could be involved in osthole activity at $1 \times 10^{-5} \mathrm{~mol} / \mathrm{L}$ [179]. Endoplasmic reticulum stress may be involved in the release of inflammatory mediators around the prosthesis, osteoclast genesis, and osteolysis. NFATc1 is a gene involved in the mechanism of osthole inhibition in this regard with tested dosage at $10^{-6}$ and $10^{-5} \mathrm{~mol} / \mathrm{L}$ [180]. Bone morphogenetic protein 2 activations triggered bone morphogenetic protein signaling which was closely associated with the bone function [181]. The chemical structure of osthole could be the reason for its role in bone formation and bone resorption. It was found that osthole, icariin, and 8-prenylnaringein sharing a similar structure, namely the prenyl group. Icariin and 8-prenylnaringein have been viewed with the function of mediating bone reconditioning and prophylaxis against osteoporosis [182].

For valine, valine as a CMC chemical compound branched-chain amino acid which could maintain and stabilize skeletal muscle. The downregulation of valine could counter the prednisolone-induced osteoporosis via regulating amino acid metabolism [183].

\section{Bone Fracture}

For genes involvement, collagen type $\mathrm{X}$, alkaline phosphatase, osteocalcin, and bone morphogenetic proteins were upregulated after osthole intervention in chondrocyte differentiation, chondrocyte maturation, and endochondral ossification [184]. From an in vivo study, total flavonoids $(5 \mathrm{~mL} / \mathrm{kg}$ per day for 90 days) could lower the bone fragility, curb the tendency of bone fracture and increase the biomechanical index such as the maximum load, fracture load, elastic load, elasticity, bending energy. Among them, elastic load, elasticity, bending energy was statistically significant $(p<0.05)$ [185].

Osteolysis

From an in vivo study, tricalcium phosphate particle-induced osteolysis could be prevented by osthole local administration $(10 \mathrm{mg} / \mathrm{kg})$ via the endoplasmic reticulum stress signaling pathway [186].

\section{Periodontitis}

From the in vitro study, osthole $\left(10^{-5} \mathrm{~m} / \mathrm{L}\right)$ with vitamin $\mathrm{C}$ co-treatment could increase cell sheet formation and osteogenic protein/gene expression in both periodontal ligament stem cells and jaw 
bone marrow mesenchymal stem cells. Osthole motivated collagen type-I, fibronectin, and integrin $\beta 1$ production and calcium accumulation for extracellular matrix mineralization because of the increase of mRNA expression of alkaline phosphatase, runt-related transcription factor 2, and osteocalcin. Osthole can directly improve bone-forming activity via stimulating cell osteogenic differentiation and bone marker gene expression [187].

\subsubsection{Tumor Diseases}

\section{Digestive System Cancer}

Osthole could significantly inhibit the growth of cholangiocarcinoma QBC939 cells in a dose and time-dependent manner with $\mathrm{IC}_{50}$ values of $0.16963 \mathrm{mmol} / \mathrm{L}$ and $0.10019 \mathrm{mmol} / \mathrm{L}$. Besides, osthole could also influence the cell growth circle to induce apoptosis at the G2/M phase via the caspase signaling pathway [188]. Osthole suppressed the clonogenicity of esophageal cell carcinomas (ESCC) cells such as KYSE150 and KYSE410 cells in a dose-dependent manner, plus, it was also noticed that osthole's inhibitory effect against ESCC cells was related to the build-up of cell cycle progression at G2/M phase and apoptosis induction with the activation of caspase-dependent pathway, the P13K/AKT (p-AKT) signaling pathway through the activation of PTEN which was responsible for P13K/AKT pathway negative regulation and cell growth inhibition [189]. For pancreatic cancer, osthole could inhibit pancreatic cancer progression, reduce tumor weight, suppress proliferation, migration, and cause apoptosis of pancreatic 02 cells. It was noticed that osthole prevented the infiltration of M2 macrophages in cancer and reduced the numbers of M2 macrophages in the spleen, In addition, osthole impeded the polarization of primary bone marrow cells into M2 macrophages, which was associated with the downregulation of the STAT6 and C/EBP $\beta$ signaling pathways in the IL-4 induced RAW 264.7 cells [190]. In the case of gastric cancer, osthole started inhibiting BGC-823 cells at a dose of $20 \mu \mathrm{g} / \mathrm{mL}$. This pattern was in a dose-dependent manner. When the inhibitory concentration $\left(\mathrm{IC}_{50}\right)$ was $100 \mu \mathrm{g} / \mathrm{mL}$, the protein expressions including caspase- 3 and caspase- 9 were upregulated by osthole to induce cell apoptosis [191]. Osthole $(100,150$, and $200 \mu \mathrm{m})$ could downregulate the protein expression of MMP-9 and vimentin to suppress TGF- $\beta$ dependent tumor invasion [192]. Another mechanism for anti-liver cancer activity was associated with bio-behavioral characteristics of hepatocellular cancer and vascular characteristics [193]. Osthole $(0.004,0.02,0.1$, and $0.5 \mu \mathrm{mol} / \mathrm{L})$ induced apoptosis-related to the downregulation of anti-apoptotic Bcl-2 expression, upregulation of proapoptotic Bax and p53 proteins. Collectively, the activation of caspases and mitochondria in HepG2 cells was involved in this aspect [194]. When it comes to lower digestive tract cancers such as colon cancer, CMC (120-200 $\mu \mathrm{g} / \mathrm{mL})$ showed cytotoxic effects and induced apoptosis in HCT116 colon cancer cells, it also attenuated mitochondria-related apoptotic proteins which included Bcl-2-associated X protein (Bax) and Bcl-2-homologous antagonist killer (Bak) in a dose-dependent manner [195]. From in vivo studies, for liver cancer, osthole $(0.25,0.5$ and $1.0 \mathrm{mmol} / \mathrm{kg})$ limited the tumor growth in a dose-dependent manner without immune toxicity in mice model. The intervention of osthole discriminately increased the proportion and quantity of $\mathrm{CD}^{+} \mathrm{T}$ cells without effects on other cells in the spleen of the test model. It also stimulated the activation of $\mathrm{CD}^{+}$and $\mathrm{CD} 8^{+} \mathrm{T}$ cells for which infiltrated the tumor [196]. Another study showed that osthole $(0.25,0.5$, and $1.0 \mathrm{mmol} / \mathrm{kg})$ could at least partially suppress NF- $\mathrm{kB}$ activity to exert cancer cell inhibition and apoptosis effect [197]. NBM-T-BMX-OS01 (BMX) (20 mg/kg) is an osthole derivative which suppresses angiogenesis via vascular endothelial growth factor receptor 2 (VEGFR2) signaling and cancer cell inhibition in HCT116 colorectal cancer cell line [198].

\section{Blood Cancer}

From in vitro studies, osthole $(100 \mu \mathrm{mol} / \mathrm{L})$ demonstrated an inhibitory effect on HL-60 acute myeloid leukemia cells. It could enhance the apoptosis induced by tumor necrosis factor-related apoptosis-inducing ligand (TRAIL). It attenuated the protein expressions by descending Bcl-2 mRNA and elevating Bax and Dr5 mRNA expression. In comparison, when osthole and TRAIL were applied together, the attenuation 
was dramatically amplified. Osthole also improved the vitality of caspase-3, caspase-8, and caspase- 9 remarkably [199]. For multiple myeloma, except downregulating Bcl-2 expression, the expression of p53 and apoptosis-related protein such as cleaved-PARP were upregulated with the tested dosage of osthole from 0 to $200 \mu \mathrm{mol} / \mathrm{L}$ [200]. The activation of the PI3K/AKT signaling pathway was involved in K562 leukemia cells inhibition and apoptosis promotion with Osthole from 0 to $20 \mu \mathrm{g} / \mathrm{mL}$ [201]. In addition to osthole ( $\mathrm{IC}_{50}=14.9$ and $9.3 \mu \mathrm{g} / \mathrm{mL}$ ), imperatorin ( $\mathrm{IC}_{50}=18.8$ and $20.2 \mu \mathrm{g} / \mathrm{mL}$ ), bergapten, isopimpinellin, and xanthotoxin all exhibited inhibitory effects on two types of leukemia cells including HL-60 and P-388 in $24 \mathrm{~h}$. More importantly, osthole and imperatorin showed high sensitivity to these two types of cells and induced apoptosis in HL-60 cells [202].

\section{Breast Cancer}

From in vitro studies, osthole $(20 \mu \mathrm{g} / \mathrm{mL})$ inhibited human breast cancer cells in a dose and time-dependent manner. It exhibited a suppressive effect on tumor angiogenic factors including vascular endothelial growth factor (VEGF) and MMP-9. It could prevent the downstream of the MAPK signaling pathway via suppressing the activity of breast cancer cells HER-2/neu [203]. Osthole $(20 \mu \mathrm{mol} / \mathrm{L})$ could dramatically increase the sensitivity of breast cancer stem cells to TRAIL. The mechanism could be attributed to the apoptotic protease activating factor-1 (Apaf-1) upregulation. This upregulation could further promote activation between caspase- 9 and Apaf- 1 with the assistance of cytochrome $C$ which initiated the process of apoptosis [204]. For breast cancer MCF-7 cell, osthole $(0-100 \mu \mathrm{mol} / \mathrm{L})$ induced the apoptosis of MCF-7 through activation of p53 signaling. Moreover, osthole increased the expression of Bax, p21, and Cytc and decreases Bcl-2 expression. G1 phase arrest may be one of the reasons for MCF-7 cells inhibition [205,206]. Another mechanism elaborated on the initiation of apoptosis for breast cancer cells BT-20 is the formation of RIP1-FADD-caspase-8 complex via CIAP2/RIP1 pathway [207]. The inhibition of TGF- $\beta 1$ expression was against the bone metastasis of breast cancer [208].

\section{Prostate Cancer}

From in vitro studies, osthole $(50 \mu \mathrm{mol} / \mathrm{L})$ could downregulate silent information regulator 1 (SIRT1) expression in prostate cancer LNCaP cells and enhance the sensitivity to doxorubicin (DOX). Osthole enhanced the DOX efficacy on the tumor cells by p53 activation, the STRT1/p53 pathway promoted apoptosis in tumor cells from mitochondria level [209]. In another type of cell, osthole (30, 60,90 , and $120 \mu \mathrm{mol} / \mathrm{L}$ ) showed a similar effect on DU145 cells [210].

\section{Nasopharyngeal Cancer}

From in vitro studies, osthole $(150 \mathrm{mg} / \mathrm{L})$ could increase sensitivity for the radiotherapy through the mechanism of downregulation of gene expression of VEGF and hypoxia-inducible factor- $1 \alpha$ (HIF-1 $\alpha$ ) and inhibition of angiogenesis [211]. In the case of tumor stem cell proliferation, osthole (20, 40 , and $80 \mu \mathrm{mol} / \mathrm{L}$ ) exhibited a similar effect on CNE2 cells in terms of its inhibition and sensitivity for radiation therapy. The possible mechanism was related to the protein expression suppression of p-GSK-3, $\beta$-catenin, and cyclin D1 [212].

\section{Cervical Cancer}

From in vitro studies, it was found that, after osthole intervention $(10 \mu \mathrm{g} / \mathrm{mL}, 150 \mu \mathrm{g} / \mathrm{mL}$, and $200 \mu \mathrm{mol} / \mathrm{L}$ ) on HeLa cervical cancer cells, the expression level of Bax m-RNA and Fas was elevated significantly, while the expression level of Bcl-2 mRNA was reduced dramatically. The cellular ROS level surged in a dose-dependent manner. Immune escape responsible factor human transforming growth factor $\beta 1$ (TGF- $\beta 1$ ) secretion was restricted by osthole. These findings indicated the possible mechanism was associated with the imbalance of Bcl-2/Bax which triggered apoptosis [213,214]. In another type of tumor cells, similar findings were obtained for Bax and Bcl-2 attenuation. At the concentrations of 20,40 and $80 \mu \mathrm{g} / \mathrm{mL}$, the expression levels of Cle-caspase-3 and Cle-caspase-9 were upregulated [215]. 
Melanoma

From in vitro studies, after osthole intervention (20,40, and $80 \mathrm{~mol} / \mathrm{L})$ on melanoma A375 cells, the mRNA level of Bcl-2 declined, same as the expression of $\mathrm{p}-\mathrm{NF}-\mathrm{\kappa B}$ and $\mathrm{Bcl}-2$ protein level in a dose-dependent manner, the mRNA level of Bax and the expression of I $\kappa B-\alpha$ increased. These findings were associated with suppression of NF- $\mathrm{kB}$ signal transduction pathway activation [216]. The melanoma B16F10 cells proliferation inhibition may attribute to methoxy group at the C-5 or C-8 position for the chemical compounds bergapten and xanthotoxin, the mechanism behind the activity of these two compounds was due to G2/M arrest via an elevation of checkpoint 1 kinase (Chk1) phosphorylation and a plummet in the level of cdc2 phosphorylation [217].

\section{Urinary Cancer}

From in vitro studies, for adrenocortical Y1 cancer cells, osthole $(1-200 \mu \mathrm{mol} / \mathrm{L})$ could attenuate adrenal cortex function and facilitate corticosterone synthesis and production via enhancing gene expressions of steroidogenic enzymes [218]. After osthole intervention (10, 25, and $50 \mu \mathrm{m})$, the corticosterone production was promoted with or without dibutyryl-CAMP $\left(\mathrm{Bu}_{2} \mathrm{CAMP}\right)$, the expression level of StAR and CYP11B1 increased in a dose-dependent manner, NR4A1, NR4A2, and NR5A1 gene expression was enhanced, the cholesterol uptake and transport to the inner mitochondrial membrane was promoted which is responsible for the synthesis of steroid hormones [219]. For bladder T24 cancer cells, osthole (50 mmol/L) could suppress the expression of COX-2, VEGF, and NF- $\mathrm{KB}$, while in contrast, caspase-3 activity had been strengthened to achieve bladder cancer cell T24 inhibition [220]. Osthole (5-160 $\mu \mathrm{mol} / \mathrm{L})$ could reverse the T24/ADM cell drug resistance to chemotherapy drugs such as adriamycin (ADM), fluorouracil, and cisplatin. The mechanism could be related to P-gp expression downregulation [221].

\section{Lung Cancer}

From in vitro studies, the combined application of both osthole (50, 100, and $200 \mu \mathrm{mol} / \mathrm{L}$ ) and cisplatin could significantly inhibit NCI-H460 cells. The mechanism was associated with the increasing production of ROS which caused the apoptosis for the tumor cells [222]. The similar inhibition phenomenon had occurred on NCI-H520 cells and LA795 cells with the dosage of osthole from $6.25 \mu \mathrm{mol} / \mathrm{L}$ to $100 \mu \mathrm{mol} / \mathrm{L}$ and from $0 \mu \mathrm{mol} / \mathrm{L}$ to $160 \mu \mathrm{mol} / \mathrm{L}$, respectively [223,224].

\section{Brain Cancer}

From in vitro studies, Osthole $(100$ and $200 \mu \mathrm{m})$ restrained the proliferation and promotes the apoptosis of human glioma cells through the upregulation of microRNA-16 and downregulation of matrix metalloproteinases-9 [225]. Osthole $(1,10$, and $30 \mu \mathrm{m})$ suppressed the migratory ability of human glioblastoma multiforme cells through inhibition of focal adhesion kinase-mediated matrix metalloproteinase-13 expression [226]. In another study, osthole (50-150 $\mu \mathrm{m})$ exerted a remarkable inhibitory effect for the proliferation of human glioma U251 cells via the PI3K/Akt signaling pathway [227].

\subsubsection{Toxicity}

For hepatotoxicity, firstly, osthole mitigated tamoxifen-induced liver injury by reducing the liver function parameters such as aminotransferase and aspartate aminotransferase in serum. Besides, the histological structure can be maintained by osthole pre-treatment. Secondly, it ameliorated tamoxifen-induced oxidative stress by decreasing the levels of hydrogen peroxide and malondialdehyde in serum, hydrogen peroxide and glutathione levels in liver, reactive oxygen species, and lipid peroxide levels. Another mechanism is that osthole $(100 \mathrm{mg} / \mathrm{kg})$ could dramatically inhibit the mRNA levels of cytokines including TNF- $\alpha$, IL-1 $\beta$, IL-6, and MCP-1, additionally, it could down-regulate the gene expressions of the CYP2D6, CYP2E1, CTP3A11, and CYP4A10 while up-regulating the gene expressions of UGT1A1, UGT1A6, UGT2B1, SULT2A1, and GSTM. It also exerted the hepaprotective effect by reducing p38 phosphorylation and exerted antioxidative effects [228]. Osthole $(10 \mathrm{mg} / \mathrm{kg})$ decreased the liver 
production of $\alpha$-smooth muscle actin ( $\alpha$-SMA), inflammatory cytokines and chemokines in thioacetamide treated rats. In addition, osthole could also lessen both TNF- $\alpha$-induced NF-kB activity and TGF- $\beta$-induced $\alpha$-SMA in hepatic stellate cells (HSCs). Taken together, osthole could inhibit both HSC activation and liver inflammation [229].

For cardiotoxicity induced by adriamycin, after osthole intervention $(20 \mathrm{mg} / \mathrm{kg})$, the lesions on the microstructure of myocardium were mitigated, the concentration of calcium in cardiomyocytes was lowered, the bioactivity of $\mathrm{Na}^{+}-\mathrm{K}^{+}$-ATP enzyme on the membrane of cardiomyocytes was lessened. Therefore, the mechanism was associated with $\mathrm{Na}^{+}-\mathrm{K}^{+}$-ATP enzyme activation, $\mathrm{Na}^{+} / \mathrm{Ca}^{2+}$ exchange, calcium concentration reduction, and calcium overload avoidance [230].

For neurotoxicity, osthole $(0.01,0.05,0.1 \mathrm{mmol} / \mathrm{L})$ protected PC12 cells from neurotoxicity induced by 1-methyl-4-phenylpyridinium ion in a dose-dependent manner. It also indicated the mechanism behind this phenomenon is down-regulating mitochondrial cytochrome $\mathrm{C}$ production to achieve energy metabolism adjustment and inhibition of dopaminergic neurons apoptosis [231].

\subsubsection{Respiratory System}

For idiopathic pulmonary fibrosis, osthole $(1,10$, and $50 \mu \mathrm{mol} / \mathrm{L})$ restrained its proliferation, collagen synthesis, and phenotypic differentiation. The mechanism could relate to the inhibition of the expression of the Ras C3 botox substrate1and the production of reactive oxygen species [232].

\subsubsection{Genito-Urinary System}

For focal segmental glomerulosclerosis management, osthole $(30 \mathrm{mg} / \mathrm{kg})$ ameliorated urine protein levels, renal function, and renal lesions. It also elevated nuclear factor E2-related factor 2 protein levels, cytosolic protein levels of heme oxygenase 1, and glutathione peroxidase activity, reduced the production of reactive oxygen species and serum levels of prostaglandin $E_{2}$, hindered renal macrophage infiltration, nuclear translocation of NF- $\mathrm{KB}$, and cyclooxygenase-2 expression, prevented podocyte injury and renal apoptosis [233]. The pharmacological effects and activities associated with this herb are presented in Appendix A (Table A1).

\subsection{Pharmacokinetics and Toxicology}

The pharmacokinetic studies have been mostly concentrated on osthole and other few compounds in a series of research projects. It has been found that osthole is widely distributed and absorbed in the plasma but slowly eliminated from the body. More importantly, it could possibly infiltrate the blood-brain barrier and the blood-testis barrier. It densely distributes on the liver, kidney, brain, and spleen, and its residues stay longer in the fatty tissues including epididymis, testicular tissues, and lungs [234]. Other experiments have revealed similar findings in both mice and rabbits $[235,236]$. For osthole metabolism and excretion, in phase I, the main metabolic pathway is 7-demethylation, 8-dehydrogenation, hydroxylation on coumarin feature and 3,4-epoxide formation, while in phase II, the sulfated conjugate is the main metabolite of osthole. CYP3A4 could be the metabolic enzyme responsable for osthole's elimination in vitro. Troleandomycin inhibited osthole metabolism in a concentration-dependent manner between 0-200 $\mu \mathrm{mol} / \mathrm{L}$. After elimination, osthole could be found as the original form in the rat urine [237]. The experiment performed on three critical chemical constituents bergapten, imperatorin, and osthole revealed the pharmacokinetic parameters $\mathrm{T}$ max were $2.18 \pm 0.58 \mathrm{~h}, 2.03 \pm 0.34 \mathrm{~h}, 2.75 \pm 0.24 \mathrm{~h}$, respectively, the $\mathrm{C}$ max readings were $1.18 \pm 0.22 \mu \mathrm{g} / \mathrm{mL}$, $7.03 \pm 1.27 \mu \mathrm{g} / \mathrm{mL}, 13.16 \pm 1.37 \mu \mathrm{g} / \mathrm{mL}$, respectively [238]. The recommended dosage is $30-120 \mathrm{mg} / \mathrm{kg}$ of osthole safe application [239]. It is indicated that osthole eliminations can be affected by some other factors and pre-existing disease in the host. For example, the rising body temperature can prolong the absorption for osthole. Ultimately it can increase the value of the area under the curve (AUC). Likewise, the acute renal failure can lead to the surge of osthole in plasma and extension of its elimination. Therefore, $\mathrm{CMC}$ dosage should be adjusted accordingly in the clinical practice to avoid toxic accumulations especially for the patients with such factors and diseases [234]. 
For toxicology, according to the records in Chinese Pharmacopoeia (2015 Edition), CMC has a limited degree of toxicity. Minor adverse effects have been reported after its use, including bitter mouth, drowsiness and stomach discomfort. The majority of CMC toxicity was transient and reversible [1]. The liver and renal toxicity have been reported from animal experiments on different experimental species such as zebrafish and mice. Accordingly, multiple toxic experiments have been conducted to investigate the mechanisms. The findings revealed that, for liver toxicity, osthole could exert toxic effects on the L02 liver cells in the time and dosage-dependent manner with the $\mathrm{IC}_{50}$ at $290.30 \mu \mathrm{mol} / \mathrm{L}$ in $24 \mathrm{~h}$. The mechanism could be related to L02 cells apoptosis via the mitochondria pathway. Meanwhile, osthole was also able to inhibit cell reproduction through down-regulating p-Histon $\mathrm{H} 3$ (ser10) expression [240].

From the comprehensive acute and long-term toxic experiments, Cnidium alcohol extract in all three dosage groups $(9.00,4.50,2.25 \mathrm{~g} / \mathrm{kg}$ ) demonstrated liver toxicity effects on mice in terms of the liver function biomarkers including aspartate aminotransferase, alanine aminotransferase, and glutamic transpeptidase. All three biomarkers' readings were lower than the normal control group after the cnidium alcohol extract intake. The blood biochemistry readings were also under the influence; however, it is not in a dose-dependent manner. More importantly, the medium lethal dosage $\left(\mathrm{LD}_{50}\right)$ was gauged as $17.45 \mathrm{~g} / \mathrm{kg}$ by gavage which is equal to 116 times of clinical dosage in the study [241]. In contrast, the $\mathrm{LD}_{50}$ number in another study was as low as $3.45 \mathrm{mg} / \mathrm{kg}$ [242]. In another in vivo study, the histopathological examination showed the cnidium extract intervened group with hepatic eosinophilic degeneration and blood vessels surrounding inflammatory cell infiltration in liver cells. For renal toxicity, the cnidium extract intervened group demonstrated blood urea nitrogen and serum creatinine ratio elevation which indicates its adverse effects on the kidney function [243]. In another aspect, in the case of medication combined application, osthole could increase the possibility of adverse effects from other medications by inhibiting the CYP3A4 vitality both in vitro and in vivo. Due to the fact CYP450 plays a significant role in medication interactions, for the total CYP450 system, CYP3A4 accounts for $30 \%$ in the liver and $70 \%$ in the intestinal wall. Therefore, the inhibition effect on CYP3A4 was detrimental to the safety of multiple medication intake [244]. Intriguingly, the liver toxicity could be mitigated by combined application with another herb, Glycyrrhiza uralensis [245].

\section{Discussion and Conclusions}

This review has summarized the knowledge of chemistry including chemical compound names and chemical structures of the constituents without references from PubChem, ChemSpider references, and previous reviews. Four hundred and twenty-nine (429) chemical constituents have been elucidated and 56 chemical structures have been summarized here for the first time, either in the form of PubChem or ChemSpider ID numbers or in the form of the details of the chemical structures. The traceable evidence distinguishes this research from previous ones which claimed the chemical compounds without evidence of the chemical ID numbers and the chemical structures. It is critical to present the chemical compounds with traceable evidence to prevent duplications and errors since a large number of chemical compounds have multiple names or synonyms. For the identified chemical compounds, they could be categorized into different derivatives: coumarins, which are the most dominant group, volatile constituents, liposoluble compounds, chromones, monoterpenoid glucosides, terpenoids, glycosides, glucide, and other compounds. In terms of pharmacological activities, osthole has showcased comprehensive activities including memory and learning enhancement, anthelmintic activity, anti-allergic activity, anti-atherosclerosis activity, analgesic activity, antibacterial activity, anti-cardiac diseases, anti-diabetic activity, anti-epilepsy activity, anti-fatty liver activity, antifungal activity, antiglioblastoma activity, hypnotic and sedative activity, anti-hypertension activity, anti-hypertrophic scar activity, organ ischemia-reperfusion, anti-cerebral ischemia activity, anti-inflammatory activity, bone health, anti-parasite activity, skin conditions, anti-thrombosis activity, anti-cancer activity, anti-hepatotoxicity activity, and other activities. From in vivo and in vitro studies, Imperatorin demonstrated anti-hypertension effects, anti-osteoporosis effects, anthelmintic effects, and anti-bacterial effects, and from computational analysis, an anti-cardiovascular disease effect had been uncovered. Total coumarins may exert anti-myocardial infarction effects, hypnotic 
effect, and anti-osteoporosis effect. Total flavonoids could display anti-osteoporosis effects. For toxicology, the current studies were mainly focused on osthole. Although the findings have presented multiple concerns regarding organ toxicity and other adverse effects. The induced dosages were still controversial due to its significant data disparity. For pharmacokinetics, the identified studies were all focused on osthole metabolism in different animal models. The findings present that osthole is widely distributed and absorbed in a fast manner in the physiological system, ranging from most of the major organs to fatty tissues after oral administration. Therefore, it raised the concern that the absorption rate is not satisfactory for clinical applications, especially in phase I. However, this shortcoming could be partially mitigated by using different administration routes and different forms of pharmaceutical products in the market such as gels and microemulsions [246].

In summary, CMC has demonstrated impressive potential for the management of various diseases in extensive research studies. However, most of such studies are overly concentrated on osthole, therefore, more research is needed to investigate other chemical constituents in this herb, and to examine the bioavailability of CMC, more pharmaceutical studies are needed.

\section{Materials and Methods}

The literature was searched in the following databases from their respective inception until May 2019: Encyclopedia of Traditional Chinese Medicine [247], PubMed (https://www.ncbi.nlm.nih.gov/pubmed/), EMBASE (https://www.embase.com/), ScienceDirect (https://www.sciencedirect.com/), SCOPUS (https: //www.scopus.com/freelookup/form/author.uri), Web of Science (https://mjl.clarivate.com/), China Network Knowledge Infrastructure (http://new.oversea.cnki.net/index/). The keywords used for the literature search included: Chinese name (蛇床子), Common English name (Common Cnidium Fruit), botanical or scientific name (Cnidium monnieri (L.) Cusson), and pharmaceutical name (Cnidii Fructus). The selection criteria included process controls of the herbal substances, reporting reference standards such as authentication of reference materials and profile chromatograms, and analytical procedures and validation data. Papers in English or Chinese language were included in this review. Scientific rigidity was determined by the chemical markers of herbs by strict parameters in testing, quantitative, and qualitative measures of the bioactive components, such as high-performance liquid chromatography, fingerprint spectrum, correlations differentiation, and stability evaluation, reference standards, and toxicological assessments. Plant voucher specimens were a guarantee for traceability of the plant material and data verification for other researchers or commercial purposes [248]. The chemical formulas of the compounds of CMC were acquired from selected studies. The chemical constituents with PubChem (https://pubchem.ncbi.nlm.nih.gov/) or ChemSpider (http://www.chemspider.com/) reference or with references from the previous comprehensive review were spared to draw chemical structures, the chemical constituents without these references were summarized. Chemical structures and molecular names were obtained using ChemDraw Professional 170.

Supplementary Materials: Supplementary materials can be found at http://www.mdpi.com/1422-0067/21/3/1006/s1.

Author Contributions: Participated in information collection and drafting: Y.S. Writing review and editing: A.W.H.Y. Review and supervision: G.B.L. All authors have read and agreed to the published version of the manuscript.

Funding: Non-financial support provided for this project.

Conflicts of Interest: The authors declare no conflict of interest.

\section{Abbreviations}

CM

DRG

MIC

6-Keto-GF1 $\alpha$

AD

ADM

AMPK

Apaf-1
Cnidium monnieri (L.)

Dorsal root ganglion

Minimal inhibitory concentration

6-keto-prostaglandin $1 \alpha$

Alzheimer's disease

Adriamycin

Adenosine monophosphate-activated protein kinase

Apoptotic protease activating factor- 1 


\begin{tabular}{|c|c|}
\hline ATP & Adenosine triphosphate \\
\hline$A \beta 25-35$ & Beta-amyloid protein fragment $25-35$ \\
\hline BACE1 & $\beta$-Site APP cleaving enzyme 1 \\
\hline Bak & Bcl-2-homologous antagonist killer \\
\hline Bax & Bcl-2-associated $\mathrm{X}$ protein \\
\hline BMX & NBM-T-BMX-OS01 \\
\hline Bu2cAMP & Dibutyryl-CAMP \\
\hline CAMKK2 & Calcium/calmodulin-dependent protein kinase kinase 2 \\
\hline cAMP & Cyclic Adenosine Monophosphate \\
\hline CFs & Cardiac fibroblasts \\
\hline cGMP & Cyclic Guanosine Monophosphate \\
\hline CGRPR1 & Calcitonin gene-related peptide receptors 1 \\
\hline Chk1 & Checkpoint 1 kinase \\
\hline cIAP2 & Cellular inhibitor of apoptosis-2 \\
\hline $\mathrm{CMC}$ & Cnidium monnieri (L.) Cusson \\
\hline COX-2 & Cyclooxygenase-2 \\
\hline DNCB & Dinitrochlorobenzene \\
\hline DNCB & Dinitrochlorobenzene \\
\hline DOX & Doxorubicin \\
\hline ESCC & Clonogenicity of esophageal cell carcinoma \\
\hline HIF- $1 \alpha$ & Hypoxia-inducible factor- $1 \alpha$ \\
\hline HSCs & Hepatic stellate cells \\
\hline IL-6 & Interleukin 6 \\
\hline IL-8 & Interleukin 8 \\
\hline iNOS & Inducible nitric oxide synthase \\
\hline IR & Infrared \\
\hline LD50 & Medium lethal dosage \\
\hline $\mathrm{MCAO} / \mathrm{R}$ & Middle cerebral artery occlusion/reperfusion, \\
\hline MMP-9 & Matrix metalloproteinase- 9 \\
\hline MTT & 3-(4,5-Dimethylthiazol-2-yl)-2,5-diphenyl tetrazolium bromide \\
\hline NIR & Near-infrared \\
\hline $\mathrm{NO}$ & Nitric oxide \\
\hline OGD/R & Oxygen-glucose deficiency/reperfusion \\
\hline OPG & Osteoprotegerin \\
\hline p-AKT & Phosphorylated AKT pathway \\
\hline PDEs & Phosphodiesterases \\
\hline PI3K/Akt-1 & Phosphatidylinositol 3 kinase (PI3K)/protein kinase B (Akt-1) \\
\hline PTEN & Phosphatase and tensin homolog \\
\hline RANKL & Receptor activator of NF- $\mathrm{kB}$ ligand \\
\hline Rip1 & Receptor-interacting protein 1 \\
\hline ROS & Reactive oxygen species \\
\hline RSD & Relative standard deviation \\
\hline SFE & Supercritical fluid extraction \\
\hline SIRT1 & Silent information regulator 1 \\
\hline TGF- $\beta$ & Transforming growth factor-beta \\
\hline TGF- $\beta 1$ & Transforming growth factor $\beta 1$ \\
\hline TRAIL & Tumour necrosis factor-related apoptosis-inducing ligand \\
\hline TXB2 & Thromboxane B2 \\
\hline UV & Ultraviolet spectra \\
\hline VEGFR2 & Vascular endothelial growth factor receptor 2 \\
\hline$\alpha-S M A$ & $\alpha$-smooth muscle actin, \\
\hline
\end{tabular}




\section{Appendix A}

Table A1. Pharmacological effects and activities of Cnidium monnieri (L.) Cusson.

\begin{tabular}{|c|c|c|c|c|}
\hline Pharmacological Effects & Tested Substance & Active Dose/Concentration & Study Types & References \\
\hline Memory and learning enhancement & Osthole & 30,15 and $5 \mathrm{ng}$ via intracranial injection & In vivo & [38] \\
\hline Memory and learning enhancement & Osthole & $40 \mathrm{mg} / \mathrm{kg}$ for 12 days via oral gavage & In vivo & [39] \\
\hline Neuro protective effect & Osthole & $40 \mathrm{mg} / \mathrm{kg}$ for 15 days via oral gavage & In vivo & [40] \\
\hline Memory and learning enhancement & Osthole & $40 \mathrm{mg} / \mathrm{kg}$ for 17 days via oral gavage & In vivo & [41] \\
\hline Memory and learning enhancement & Osthole & 12.5 and $25 \mathrm{mg} / \mathrm{kg}$ via intracranial injection & In vivo & [42] \\
\hline Neuro protective effect & Osthole & $40 \mathrm{mg} / \mathrm{kg}$ for 15 days via oral gavage & In vivo & [44] \\
\hline Neuro protective effect & Osthole & 50 and $100 \mu \mathrm{mol} / \mathrm{L}$ & In vitro & [45] \\
\hline Memory and learning enhancement & Osthole & 0.1 and $0.5 \mu \mathrm{mol} / \mathrm{L}$ & In vivo & [46] \\
\hline Neuro protective effect & Osthole & 1050 and $100 \mu \mathrm{mol} / \mathrm{L}$ & In vitro & [47] \\
\hline Neuro protective effect & Osthole & 10,50 and $100 \mu \mathrm{mol} / \mathrm{L}$ & In vivo & [48] \\
\hline Neuro protective effect & Osthole & $100 \mu \mathrm{mol} / \mathrm{L}$ & In vivo & [49] \\
\hline Neuro protective effect & Osthole & 10,50 , and $100 \mu \mathrm{mol} / \mathrm{L}$ & In vitro & [50] \\
\hline Neuro protective effect & Osthole & 10,50 , and $100 \mu \mathrm{mol} / \mathrm{L}$ & In vivo & [51] \\
\hline Neuro protective effect & Osthole & $100 \mu \mathrm{mol} / \mathrm{L}$ via abdominal injection & In vivo & [52] \\
\hline Brain hemorrhage protective effect & Osthole & $15 \mathrm{mg} / 10 \mathrm{~g}$ via abdominal injection & In vivo & [53] \\
\hline Anti-epilepsy effect & Osthole & $50 \mathrm{mg} / \mathrm{kg}$ for 10 days via gavage & In vivo & [54] \\
\hline Anti-epilepsy effect & Osthole & $50 \mathrm{mg} / \mathrm{kg}$ for 10 days via gavage & In vivo & [55] \\
\hline Anti-epilepsy effect & Osthole & $50 \mathrm{mg} / \mathrm{kg}$ for 10 days via gavage & In vivo & [56] \\
\hline Anti-epilepsy effect & Osthole & $1,10,100 \mathrm{mmol} / \mathrm{L}$ & In vitro & [57] \\
\hline Hypnotic and sedative effect & Alcohol extract of CMC & $62.5 \mathrm{mg} / \mathrm{kg}$ for 3 days via gavage & In vivo & [58] \\
\hline Hypnotic and sedative effect & $65 \%$ and $95 \%$ alcohol extract of $\mathrm{CMC}$ & $62.5 \mathrm{mg} / \mathrm{kg}$ for 3 days via gavage & In vivo & [59] \\
\hline Hypnotic and sedative effect & Hypnotic active component of CMC & 130,260 , and $520 \mathrm{mg} / \mathrm{kg}$ twice a day for 16 days via gavage & In vivo & [60] \\
\hline Hypnotic effect & $\begin{array}{l}\text { Total coumarin, osthole, imperatorin, } \\
\text { isopimpinellin, and bergapten }\end{array}$ & 25,50 , and $100 \mathrm{mg} / \mathrm{kg}$ for 3 days via gavage & In vivo & [61] \\
\hline Hypnotic effect & Osthole & $25 \mathrm{mg} / \mathrm{kg} /$ day, 7 days via abdominal injection & In vivo & [62] \\
\hline Hypnotic effect & Osthole & $40,80,160 \mathrm{mg} / \mathrm{kg}$ for 6 days via gavage & In vivo & [63] \\
\hline
\end{tabular}


Table A1. Cont.

\begin{tabular}{|c|c|c|c|c|}
\hline Pharmacological Effects & Tested Substance & Active Dose/Concentration & Study Types & References \\
\hline Anxiolytic effect & Osthole & 1.753 .57 .00 and $14 \mathrm{mg} / \mathrm{kg}$ via oral administration for 6 days & In vivo & [64] \\
\hline Anti-asthmatic effect & Osthole & 2550 and $100 \mathrm{mg} / \mathrm{kg}$ via intraperitoneal administration & In vivo & [65] \\
\hline Anti-asthmatic effect & Osthole & 10 and 50 mg.kg via abdominal injection & In vivo & [66] \\
\hline Anti-asthmatic effect & Osthole & $0.1,1$, and $10 \mu \mathrm{m}$ & In vitro & [67] \\
\hline Anti-asthmatic effect & Osthole & 10 and 40 mg.kg via abdominal injection & In vivo & [68] \\
\hline Anti-allergic effect & Osthole & 150,300 , and $450 \mathrm{ng} / \mathrm{mL}$ & In vitro & [69] \\
\hline Anti-allergic effect & Osthole & $0.25,0.5$ and $1 \mathrm{~g} / \mathrm{mL}$ & In vivo & [70] \\
\hline Anti-allergic effect & Osthole with voucher number (CM-99001) & 200 and $500 \mathrm{mg} / \mathrm{kg}$ via oral administration & In vivo & [71] \\
\hline Anti-allergic effect & Osthole & 150 and $300 \mathrm{ng} / \mathrm{mL}$ & In vitro & [72] \\
\hline Anti-allergic effect & Methanol extract of CMC & $100 \mu \mathrm{g} / \mathrm{mL}$ & In vitro & [73] \\
\hline Anti-atherosclerosis effect & Osthole & 10 and $30 \mathrm{mg} \cdot \mathrm{kg}$ for 16 days & In vivo & [74] \\
\hline Anti-atherosclerosis effect & Osthole & 10 and $20 \mathrm{mg} / \mathrm{kg}$, and $40 \mathrm{mg} . \mathrm{kg}$ via oral gavage & In vivo & [75] \\
\hline Anti-atherosclerosis effect & Osthole & $10,20,40,60$ and $80 \mu \mathrm{mol} / \mathrm{L}$ & In vitro & [76] \\
\hline Anti-cardiovascular diseases & Imperatorin & N/A & $\begin{array}{l}\text { Computational } \\
\text { analysis }\end{array}$ & [77] \\
\hline Anti-cardiovascular diseases & Total coumarins & $20 \mathrm{mg} / \mathrm{kg}$ via oral gavage & In vivo & [78] \\
\hline Anti-cardiovascular diseases & Osthole & $50 \mathrm{mg} / \mathrm{kg}$ via abdominal injection & In vivo & [79] \\
\hline Anti-cardiovascular diseases & Osthole & $25 \mathrm{mg} / \mathrm{kg}$ via femur vein injection & In vivo & [80] \\
\hline Anti-cardiovascular diseases & Osthole & $25 \mathrm{mg} / \mathrm{kg}$ via internal jugular vein & In vivo & [81] \\
\hline Anti-cardiovascular diseases & Osthole & $10,20 \mathrm{mg} / \mathrm{kg}$ for 28 days via oral gavage & In vivo & [82] \\
\hline Anti-cardiovascular diseases & Osthole & $10,20 \mathrm{mg} / \mathrm{kg}$ for 28 days via oral gavage & In vivo & [83] \\
\hline Anti-cardiovascular diseases & Osthole & $10,50,100,200,300,400,500 \mu \mathrm{mol} / \mathrm{L}$ & In vivo & [84] \\
\hline Anti-cardiovascular diseases & Osthole & $100,200,300 \mu \mathrm{mol} / \mathrm{L}$ & In vitro & [85] \\
\hline Anti-cardiovascular diseases & Osthole & $200 \mu \mathrm{mol} / \mathrm{L}$ & In vitro & [86] \\
\hline Anti-cardiovascular diseases & Osthole & $10^{-9}$ to $10^{-5} \mathrm{M}$ & In vitro & [87] \\
\hline Anti-cardiovascular diseases & Osthole & $1.25,2.5,5,10,20$, and $25 \mu \mathrm{g} / \mathrm{mL}$ & In vitro & [88] \\
\hline Anti-hypertension effect & $\begin{array}{l}\text { Imperatorin, xanthotoxol, and other } \\
\text { Imperatorin derivatives }\end{array}$ & $0.1 \mu \mathrm{M}$ to $0.1 \mathrm{mM}$ & In vitro & [89] \\
\hline Anti-hypertension effect & Imperatorin & $\begin{array}{c}\text { 3, 10,30 } \mu \mathrm{M}, \\
6.25-25 \mathrm{mg} / \mathrm{kg} \text { per day }\end{array}$ & In vivo+ In vitro & {$[90]$} \\
\hline
\end{tabular}


Table A1. Cont.

\begin{tabular}{|c|c|c|c|c|}
\hline Pharmacological Effects & Tested Substance & Active Dose/Concentration & Study Types & References \\
\hline Anti-hypertension effect & Osthole & $0.05 \%$ osthol to the control diet by weight & In vivo & [91] \\
\hline Anti-hypertension effect & $\begin{array}{l}\text { Imperatorin isolated from CMC with patent } \\
\text { number ZL200610042997.2 }\end{array}$ & $6.25,12.5,25 \mathrm{mg} / \mathrm{kg}$ per day, for 10 weeks via oral gavage & In vivo & [92] \\
\hline Anti-hypertension effect & $\begin{array}{l}\text { Imperatorin with patent number } \\
\text { ZL2006100042997.2 }\end{array}$ & $6.25,12.5,25 \mathrm{mg} / \mathrm{kg}$ per day, for 13 weeks & In vivo & [93] \\
\hline Anti-hypertension effect & $\begin{array}{l}\text { Imperatorin with patent number } \\
\text { ZL2006100042997.2 }\end{array}$ & $1-100 \mu \mathrm{M}$ & In vitro & [94] \\
\hline Anti-hypertension effect & Osthole & $10,30,60,100 \mathrm{mmol} / \mathrm{L}$ & In vitro & [95] \\
\hline Anti-organ ischemia effect & Osthole & $40 \mathrm{mg} / \mathrm{kg}$ via abdominal injection & In vivo & [96] \\
\hline Anti-organ ischemia effect & Osthole & $5,10,20 \mathrm{mg} / \mathrm{kg}$ via abdominal injection & In vivo & [97] \\
\hline Renal ischemia-reperfusion & Osthole & $40 \mathrm{mg} / \mathrm{kg}$ via abdominal injection & In vivo & [98] \\
\hline Retina ischemia-reperfusion & Osthole & $20,40,80 \mathrm{mg} / \mathrm{kg}$ via abdominal injection & In vivo & [99] \\
\hline Anti-organ ischemia effect & Osthole & $5,25 \mathrm{mg} / \mathrm{kg}$ via abdominal injection & In vivo & [100] \\
\hline Anti-organ ischemia effect & Osthole & 10 and $50 \mathrm{mg} / \mathrm{kg}$ via intraperitoneal injection & In vivo & [101] \\
\hline Anti-organ ischemia effect & Osthole & $25 \mathrm{mg} / \mathrm{kg}$ via femur vein drip & In vivo & [102] \\
\hline Anti-cerebral ischemia activity & Osthole & 25,50 , and $100 \mathrm{mg} / \mathrm{kg}$ via abdominal injection & In vivo & [103] \\
\hline Anti-cerebral ischemia activity & Osthole & 4,8 , and $16 \mathrm{mg} / \mathrm{kg}$ for 14 days via intraperitoneal injection & In vivo & [104] \\
\hline Anti-cerebral ischemia activity & Osthole & 25,50 , and $100 \mathrm{mg} / \mathrm{kg}$ via intraperitoneal injection & In vivo+ In vitro & [105] \\
\hline Anti-cerebral ischemia activity & Osthole & $100 \mathrm{mg} / \mathrm{kg}$ via intraperitoneal injection & In vivo & [106] \\
\hline Anti-cerebral ischemia activity & Osthole & 12.5 and $25 \mathrm{mg} / \mathrm{kg}$ for 14 days via intraperitoneal injection & In vivo & [107] \\
\hline Anti-cerebral ischemia activity & Osthole & 5 and $10 \mathrm{mg} / \mathrm{kg}$ via sublingual vein injection & In vivo & [108] \\
\hline Anti-cerebral ischemia activity & Osthole & 4,8 , and $16 \mathrm{mg} / \mathrm{kg}$ via intraperitoneal injection & In vivo & [109] \\
\hline Anti-thrombosis effect & Osthole & $\begin{array}{c}10,20,40 \mathrm{mg} / \mathrm{kg} / \text { day for } 7 \text { days via intragastric } \\
\text { administration }\end{array}$ & In vivo & [110] \\
\hline Anti-coagulation effect & Osthole & $0.95-3.78 \mathrm{mg} / \mathrm{mL}$ & In vitro & [111] \\
\hline Analgesic effect & Osthole & $1 \mathrm{mg}$ via epidural injection & In vivo & [112] \\
\hline Analgesic effect & Osthole & $1 \mathrm{mg}$ via epidural injection & In vivo & [113] \\
\hline Analgesic effect & Osthole & $1 \mathrm{mg}$ via epidural injection & In vivo & [114] \\
\hline Analgesic effect & Osthole & $0.2,0.5$, and $1 \mathrm{~g} / \mathrm{mL}$ & In vitro & [115] \\
\hline Analgesic effect & Osthole & $20 \mathrm{~g} / \mathrm{L}$ and $50 \mathrm{~g} / \mathrm{L}$ & In vitro & [116] \\
\hline
\end{tabular}


Table A1. Cont.

\begin{tabular}{|c|c|c|c|c|}
\hline Pharmacological Effects & Tested Substance & Active Dose/Concentration & Study Types & References \\
\hline Anti-fatty liver effect & Osthole & 10,20 , and $40 \mathrm{mg} / \mathrm{kg}$ for 6 weeks via gavage & In vivo & [117] \\
\hline Anti-fatty liver effect & Osthole & 10,20 , and $40 \mathrm{mg} / \mathrm{kg}$ for 6 weeks via gavage & In vivo & [118] \\
\hline Anti-fatty liver effect & Osthole & $0.1 \mathrm{~mL} / 10 \mathrm{~g}$ body weight per day for 4 weeks via gavage & In vivo & [119] \\
\hline Anti-fatty liver effect & Osthole & $12.5,25,50$, and $100 \mu \mathrm{mol} / \mathrm{L}$ & In vitro & [120] \\
\hline Anti-fatty liver effect & Osthole & 10,20 , and $40 \mathrm{mg} / \mathrm{kg}$ for 4 weeks via oral administration & In vivo & [121] \\
\hline Anti-inflammatory effect & Osthole & $50 \mathrm{mg} / \mathrm{kg}$ via oral administration for 7 days & In vivo & [122] \\
\hline Anti-inflammatory effect & Osthole & 10 and $30 \mathrm{mg} / \mathrm{kg}$ & In vivo & [123] \\
\hline Anti-inflammatory effect & Osthole & 10,20 , and $30 \mathrm{mg} / \mathrm{kg}$ via abdominal injection & In vivo & [124] \\
\hline Anti-inflammatory effect & Cnidium Lactone Micro & 2,4 , and $8 \mathrm{mg} / \mathrm{mL}$ & In vivo & [125] \\
\hline Anti-inflammatory effect & Peroxyauraptenol, auraptenol & $\begin{array}{l}\text { Peroxyauraptenol:10 } \mu \mathrm{M} \\
\quad \text { Auraptenol: } 100 \mu \mathrm{M}\end{array}$ & In vitro & [126] \\
\hline Anti-inflammatory effect & Osthole & $40 \mathrm{mg} / \mathrm{kg}$ for 4 days via gavage & In vivo & [127] \\
\hline Anti-inflammatory effect & Osthole & $\begin{array}{c}\text { 100, } 200 \mathrm{mg} / \mathrm{kg} \text { twice a day with } 12 \mathrm{~h} \text { interval via abdominal } \\
\text { injection }\end{array}$ & In vivo & [128] \\
\hline Anti-inflammatory effect & Osthole & 4,7, and $10 \mu \mathrm{g} / \mathrm{mL}$ & In vitro & [129] \\
\hline Anti-inflammatory effect & Osthole & $12.5-100 \mu \mathrm{mol} / \mathrm{L}$ & In vitro & [130] \\
\hline Anti-inflammatory effect & Osthole & $10 \mu \mathrm{g} / \mathrm{mL}$ & In vitro & [131] \\
\hline Anti-inflammatory effect & $\begin{array}{l}17 \text { Chemical compounds isolated from CMC } \\
\text { with voucher number (CM-201010) }\end{array}$ & $\begin{array}{c}\mathrm{IC}_{50} \leq 7.31 \mu \mathrm{g} / \mathrm{mL} \text { for } 3^{\prime} \text {-O-methylmurraol, murraol, } \\
\text { xanthotoxin, imperatorin, cnidimol A, } \\
\mathrm{IC}_{50} \leq 7.83 \mu \mathrm{g} / \mathrm{mL} \text { for osthenol, peroxyauraptenol, } \\
\text { demethylauraptenol, bergapten, cnidimol A }\end{array}$ & In vitro & [132] \\
\hline Anti-fatigue effect & $\begin{array}{l}\text { Osthole obtains in the Japanese formula which } \\
\text { contains CMC and other } 14 \text { herbs }\end{array}$ & $10 \mathrm{~mL} / \mathrm{kg}$ via oral administration & In vitro & [133] \\
\hline Anti-fatigue effect & $\mathrm{CMC}$ & $0.75,1.5,4.5 \mathrm{~g} / \mathrm{kg}$ & In vivo & [134] \\
\hline Anti-oxidant effect & Osthole & $\begin{aligned} \mathrm{O}_{2}^{-}: & 0.5 \mathrm{~mL} ; \mathrm{OH}: 0.1,0.2,0.3,0.4,0.5,0.6 \mathrm{~mL} \text {; Diphenyl-tert } \\
& \text { amine-based radical: } 0.1,0.2,0.3,0.4,0.5,0.6 \mathrm{~mL}\end{aligned}$ & In vitro & [135] \\
\hline Anti-bacterial effect & CMC ethanol extract & $250 \mathrm{mg} / \mathrm{mL}$ & In vitro & [136] \\
\hline Anti-bacterial effect & Osthole & $\begin{array}{l}\text { Osthole }\left(\mathrm{IC}_{50}=34 \mu \mathrm{M}\right) \\
\text { Imperatorin }\left(\mathrm{IC}_{50}=28 \mu \mathrm{M}\right)\end{array}$ & In vitro & [137] \\
\hline Anti-bacterial effect & CMC extract & MIC: $65.2-125 \mu \mathrm{g} / \mathrm{mL}$ & In vitro & [138] \\
\hline Anti-bacterial effect & CMC extract & $60 \mathrm{mg} / \mathrm{mL}$ & In vitro & [139] \\
\hline
\end{tabular}


Table A1. Cont.

\begin{tabular}{|c|c|c|c|c|}
\hline Pharmacological Effects & Tested Substance & Active Dose/Concentration & Study Types & References \\
\hline Anti-bacterial effect & CMC extract & $5 \mathrm{~g} / \mathrm{mL}$ & In vivo+ In vitro & [140] \\
\hline Anti-bacterial effect & $\begin{array}{c}\text { CMC } \\
(\text { CBNU201012-CM) }\end{array}$ & $300 \mathrm{mg} / \mathrm{kg}$ per day for 5 days via oral gavage & In vivo+ In vitro & [141] \\
\hline Anti-HIV effect & Osthole & $\mathrm{IC}_{50}: 1.6 \mu \mathrm{M}$ & In vitro & [142] \\
\hline Anti-fungal effect & $\mathrm{CMC}$ & Average MIC: $12.5 \mathrm{~g} / \mathrm{L}$ & In vitro & [143] \\
\hline Anti-fungal effect & Osthole and Fluconazole & $4-16 \mu \mathrm{g} / \mathrm{mL}$ & In vitro & [144] \\
\hline Anti-fungal effect & Osthole & $0.5 \mathrm{~g}$ & In vitro & [146] \\
\hline Anthelmintic effect & Osthole & $100 \mathrm{mg} / \mathrm{kg}$ for 6 weeks via oral administration & In vivo+ In vitro & [147] \\
\hline Anthelmintic effect & Osthole & $10 \mathrm{mg} / \mathrm{mL}$ & In vitro & [148] \\
\hline Anthelmintic effect & Osthole and Imperatorin & $50 \mathrm{mg} / \mathrm{L}$ & In vivo & [149] \\
\hline Anthelmintic effect & Osthole & $0.56,1.12,2.24$, and $4.48 \mathrm{mg} / \mathrm{mL}$ & In vitro & [150] \\
\hline Anthelmintic effect & Osthole & $\mathrm{IC}_{50} 1.345 \mathrm{mg} / \mathrm{mL}$ & In vitro & [151] \\
\hline Anti-diabetic diseases & Osthole & $20 \mathrm{mg} / \mathrm{kg}$ intraperitoneal injection & In vivo & [152] \\
\hline Anti-diabetic diseases & Osthole & 1,10 , and $50 \mathrm{mg} / \mathrm{kg}$ & In vitro & [153] \\
\hline Anti-diabetic diseases & Osthole & $0.5,1.25,2.5,5,10,20$, and $40 \mu \mathrm{mol} / \mathrm{L}$ & In vitro & [154] \\
\hline Anti-diabetic diseases & Osthole & $100 \mu \mathrm{mol} / \mathrm{L}$ & In vitro & [155] \\
\hline Anti-diabetic diseases & Osthole & $0-200 \mu \mathrm{M}$ & In vitro & [156] \\
\hline Stimulate Thyroid function effect & Osthole and total courmarins & $1 \mathrm{~mL} / \mathrm{d}$ for 15 days via intragastric administration & In vivo & [157] \\
\hline Estrogen-like effect & Osthole & $\begin{array}{c}0.75,1.50,3.00,6.00,12.00,24.00 \mathrm{mg} / \mathrm{kg} \text { for } 10 \text { days via } \\
\text { abdominal injection }\end{array}$ & In vivo & [158] \\
\hline Anti-hypertrophic scar effect & Osthole & $10-32 \mu \mathrm{mol} / \mathrm{L}$ & In vitro & [159] \\
\hline Anti-hypertrophic scar effect & Osthole & $1.25 \times 10^{4} \mathrm{~mol} / \mathrm{L}$ & In vitro & {$[160]$} \\
\hline Anti-fibrosis effect & Osthole & $5-50 \mu \mathrm{mol} / \mathrm{L}$ & In vitro & [161] \\
\hline Anti-psoriasis effect & Osthole & $1.8 \times 10^{-4} \mathrm{~mol} / \mathrm{L}$ & In vitro & [161] \\
\hline Anti-psoriasis effect & CMC with voucher number (PSO05) & IC50: $114.6 \mu \mathrm{g} / \mathrm{mL}$ & In vitro & [163] \\
\hline Anti-atopic dermatitis effect & Osthole & 1.0 and $5.0 \mathrm{mg} / \mathrm{mL}$ & In vivo & [164] \\
\hline Anti-atopic dermatitis effect & Osthole & 10,20 and $40 \mathrm{mg} / \mathrm{kg}$ & In vivo & [165] \\
\hline Anti-atopic dermatitis effect & Osthole from Osthole microemulsion & 2,4 , and $8 \mathrm{mg} / \mathrm{mL}$ & In vivo & [166] \\
\hline Anti-pruritic effect & $\mathrm{CMC}$ & $0.1 \mathrm{~mL} / 100 \mathrm{~g}$ & In vivo & [167] \\
\hline
\end{tabular}


Table A1. Cont.

\begin{tabular}{|c|c|c|c|c|}
\hline Pharmacological Effects & Tested Substance & Active Dose/Concentration & Study Types & References \\
\hline Anti-pruritic effect & Osthole, Imperatorin, and Isopimpinellin & $200 \mathrm{mg} / \mathrm{kg}$ and $500 \mathrm{mg} / \mathrm{kg}$ via oral administration & In vivo & [168] \\
\hline Anti-osteoporosis effect & $\begin{array}{l}6 \text { total coumarins (osthole, imperatorin, } \\
\text { bergapten, isopimpinellin, xanthotoxin, } \\
\text { xanthotoxol) }\end{array}$ & $5 \mathrm{~g} / \mathrm{kg}, 6$ times per week & In vivo & [169] \\
\hline Anti-osteoporosis effect & Total coumarins & $2.5 \mathrm{~mL} / \mathrm{kg}$, 8 weeks via oral gavage & In vivo & [170] \\
\hline Anti-osteoporosis effect & Imperatorin and Osthole & $\begin{array}{l}\text { Imperatorin: } 0.1 \mu \mathrm{mol} / \mathrm{L} \\
\text { Osthole: } 10 \mu \mathrm{mol} / \mathrm{L}\end{array}$ & In vitro & [171] \\
\hline Anti-osteoporosis effect & Osthole & $6.7 \mathrm{mg} / \mathrm{kg}$, 6 times per week for 12 weeks & In vivo & [172] \\
\hline Anti-osteoporosis effect & Osthole & $200 \mathrm{mg} / \mathrm{kg}$ for 5 weeks via oral gavage & In vivo & [173] \\
\hline Anti-osteoporosis effect & Osthole & $20 \mathrm{mg} / \mathrm{kg}$ via local injection & In vivo & [174] \\
\hline Anti-osteoporosis effect & Osthole & $20 \mathrm{mg} / \mathrm{kg}$ for 7 days via oral gavage & In vivo+ In vitro & [175] \\
\hline Anti-osteoporosis effect & Osthole & $1 \times 10^{-6}$ and $1 \times 10^{-8} \mathrm{~mol} / \mathrm{L}$ for $48 \mathrm{~h}$ and $72 \mathrm{~h}$ & In vitro & [175] \\
\hline Anti-osteoporosis effect & Osthole & $1 \times 10^{-1}, 1 \times 10^{-2}, 1 \times 10^{-3}, 1 \times 10^{-4} \mathrm{~mol} / \mathrm{l}$ & In vitro & [176] \\
\hline Anti-osteoporosis effect & Osthole & $1 \times 10^{-4}, 1 \times 10^{-5}, 1 \times 10^{-6}, 1 \times 10^{-7} \mathrm{~mol} / \mathrm{L}$ & In vitro & [177] \\
\hline Anti-osteoporosis effect & Osthole & $0,6.25,12.5,25,50 \mu \mathrm{mol} / \mathrm{L}$ & In vitro & [178] \\
\hline Anti-osteoporosis effect & Bone-targeted osthole & $10^{-4}, 10^{-5}, 10^{-6}, 10^{-7} \mathrm{mmol} / \mathrm{L}$ & In vitro & [179] \\
\hline Anti-osteoporosis effect & Osthole & $100,50,25 \mu \mathrm{mol} / \mathrm{L}$ & In vitro & [180] \\
\hline Anti-osteoporosis effect & Osthole & $1 \times 10^{-5} \mathrm{~mol} / \mathrm{L}$ & In vitro & [181] \\
\hline Anti-osteoporosis effect & Osthole & $10^{-5} \mathrm{~mol} / \mathrm{L}$ & In vitro & [182] \\
\hline Anti-osteoporosis effect & Bone-targeted Osthole & $10^{-5} \mathrm{~mol} / \mathrm{L}$ & In vitro & [183] \\
\hline Anti-osteoporosis effect & Osthole & $10^{-7}, 10^{-6}, 10^{-5}$, and $10^{-4} \mathrm{~mol} / \mathrm{L}$ & In vitro & [184] \\
\hline Anti-osteoporosis effect & Gushudan, a chinese herbal formula with CMC & $30 \mathrm{~g} / \mathrm{kg}$ per day for 12 weeks via oral administration & In vivo & [185] \\
\hline Bone fracture healing effect & Osthole & $20 \mathrm{mg} / \mathrm{kg}$ for $1,2,3$ weeks among 3 groups via oral gavage & In vivo+ In vitro & [186] \\
\hline Anti-osteoporosis effect & Total flavonoids & $5 \mathrm{~mL} / \mathrm{kg}$ per day for 90 days & In vivo & [187] \\
\hline Anti-osteoporosis effect & Osthole & $10 \mathrm{mg} / \mathrm{kg}$ per day for 5 days via subcutaneous injection & In vivo & [188] \\
\hline Anti-periodontitis effect & Osthole & $10^{-4}, 10^{-5}, 10^{-6}$, and $10^{-7} \mathrm{~m} / \mathrm{L}$ for 3 days & In vivo+ In vitro & [189] \\
\hline Anti-cancer effect & Osthole & $0.05,0.1,0.15 \mathrm{mmol} / \mathrm{L}$ & In vitro & [190] \\
\hline Anti-cancer effect & Osthole & $0,20,40,80,120,160,200 \mu \mathrm{M}$ & In vitro & [191] \\
\hline Anti-cancer effect & Osthole & $0,20,80$, and $160 \mu \mathrm{M}$ for 14 days intraperitoneal injection & In vivo+ In vitro & [192] \\
\hline
\end{tabular}


Table A1. Cont.

\begin{tabular}{|c|c|c|c|c|}
\hline Pharmacological Effects & Tested Substance & Active Dose/Concentration & Study Types & References \\
\hline Anti-cancer effect & Osthole & $0,5,10,20,40,80,120$, and $160 \mu \mathrm{g} / \mathrm{mL}$ & In vitro & [193] \\
\hline Anti-cancer effect & Osthole & $50,100,150$, and $200 \mu \mathrm{M}$ for 24,48 , and $72 \mathrm{~h}$ & In vitro & [194] \\
\hline Anti-cancer effect & Osthole & $2.5 \mu \mathrm{g} / \mathrm{g} /$ day for 4 weeks via intragastric administration & In vivo & [195] \\
\hline Anti-cancer effect & Osthole & $0.004,0.02,0.1,0.5$ and $1.0 \mu \mathrm{mol} / \mathrm{mL}$ for $24 \mathrm{~h}$ & In vitro & [196] \\
\hline Anti-cancer effect & CMC extract & $120-200 \mu \mathrm{g} / \mathrm{mL}$ & In vitro & [197] \\
\hline Anti-cancer effect & Osthole & $\begin{array}{c}0.25,0.5 \text {, and } 1.0 \mathrm{mmol} / \mathrm{kg} \text { once every other day for } 2 \text { weeks } \\
\text { via intraperitoneal administration }\end{array}$ & In vivo & [198] \\
\hline Anti-cancer effect & Osthole & $\begin{array}{l}61,122 \text { and } 244 \mathrm{mg} / \mathrm{kg} \text { via intraperitoneal administration for } \\
2 \text { weeks }\end{array}$ & In vivo+ In vitro & [199] \\
\hline Anti-cancer effect & Osthole derivative NBM-T-BMX-OS01 & $20 \mathrm{mg} / \mathrm{kg} /$ day for 10 days via intraperitoneal injection & In vivo+ In vitro & [200] \\
\hline Anti-cancer effect & Osthole & $12.5,25,50,100$, and $200 \mu \mathrm{mol} / \mathrm{L}$ & In vitro & [201] \\
\hline Anti-cancer effect & Osthole & $0,10,20,40,80,120,160$, and $200 \mu \mathrm{mol} / \mathrm{L}$ & In vitro & [202] \\
\hline Anti-cancer effect & Osthole & $0,5,10$, and $20 \mu \mathrm{g} / \mathrm{mL}$ & In vitro & [203] \\
\hline Anti-cancer effect & $\begin{array}{l}\text { Osthole, imperatorin, bergapten, } \\
\text { isopimpinellin, and xanthotoxin }\end{array}$ & $\begin{array}{c}\text { HL-60: } \\
\text { IC }{ }_{50} \text { of osthole: } 14.9 \mu \mathrm{g} / \mathrm{mL} \\
\text { IC }_{50} \text { of imperatorin: } 18.8 \mu \mathrm{g} / \mathrm{mL} \text {. } \\
\text { P-388: } \\
\text { IC }_{50} \text { of osthole: } 9.3 \mu \mathrm{g} / \mathrm{mL} \\
\text { IC }_{50} \text { of imperatorin: } 20.2 \mu \mathrm{g} / \mathrm{mL} \text {. }\end{array}$ & In vitro & [204] \\
\hline Anti-cancer effect & Osthole & $0,20,40,60,80,100,200 \mu \mathrm{mol} / \mathrm{L}$ for 24 and $48 \mathrm{~h}$ & In vitro & [205] \\
\hline Anti-cancer effect & Osthole & $20 \mu \mathrm{mol} / \mathrm{L}$ & In vitro & [206] \\
\hline Anti-cancer effect & Osthole & $0,25,50$, and $100 \mu \mathrm{mol} / \mathrm{L}$ & In vitro & [207] \\
\hline Anti-cancer effect & Osthole & $0,20,40,60,80$, and $100 \mu \mathrm{mol} / \mathrm{L}$ & In vitro & [208] \\
\hline Anti-cancer effect & Osthole & $20 \mu \mathrm{mol} / \mathrm{L}$ & In vitro & [209] \\
\hline Anti-cancer effect & Osthole & $0,10,20,30,40,50,60,70,80,90$, and $100 \mu \mathrm{g} / \mathrm{mL}$ & In vitro & [210] \\
\hline Anti-cancer effect & Osthole & $50 \mu \mathrm{mol} / \mathrm{L}$ & In vitro & [211] \\
\hline Anti-cancer effect & Osthole & $0,30,60,90$, and $120 \mu \mathrm{mol} / \mathrm{L}$ & In vitro & [212] \\
\hline Anti-cancer effect & Osthole & $\begin{array}{c}1.5 \mu \mathrm{g} /(\mathrm{g} \cdot 10 \mu \mathrm{L}) \text { every other day for } 7 \text { times via abdominal } \\
\text { injection }\end{array}$ & In vivo+ In vitro & [213] \\
\hline Anti-cancer effect & Osthole & $0,20,40$, and $80 \mu \mathrm{g} / \mathrm{mL}$ & In vitro & [214] \\
\hline Anti-cancer effect & Osthole & $20,40,80,120,160$, and $200 \mu \mathrm{mol} / \mathrm{L}$ & In vitro & [215] \\
\hline Anti-cancer effect & Osthole & $10 \mu \mathrm{g} / \mathrm{mL}$ & In vitro & [216] \\
\hline
\end{tabular}


Table A1. Cont.

\begin{tabular}{|c|c|c|c|c|}
\hline Pharmacological Effects & Tested Substance & Active Dose/Concentration & Study Types & References \\
\hline Anti-cancer effect & Osthole & $20,40,80 \mu \mathrm{g} / \mathrm{mL}$ & In vitro & [217] \\
\hline Anti-cancer effect & Osthole & $20,40,80 \mathrm{~mol} / \mathrm{L}$ & In vitro & [218] \\
\hline Anti-cancer effect & $\begin{array}{l}\text { Bergapten, Xanthotoxin, Isopimpinellin, } \\
\text { Columbianetin, Columbianadin, Edultin, } \\
\text { Cniforin, Cniforin B, and Archangelicin }\end{array}$ & $\begin{array}{c}0.5 \text { or } 1.0 \mathrm{mg} / \mathrm{kg} \text { administered intraperitoneally daily for } 20 \\
\text { days }\end{array}$ & In vivo+ In vitro & [219] \\
\hline Anti-cancer effect & Osthole & 10,25 , and $50 \mu \mathrm{mol} / \mathrm{L}$ & In vitro & [220] \\
\hline Anti-cancer effect & Osthole & 10,25 , and $50 \mu \mathrm{M}$ & In vitro & [221] \\
\hline Anti-cancer effect & Osthole & $5,50,100 \mu \mathrm{mol} / \mathrm{L}$ & In vitro & [222] \\
\hline Anti-cancer effect & Osthole & $5,10,20,40,60,80$, and $160 \mu \mathrm{mol} / \mathrm{L}$ & In vitro & [223] \\
\hline Anti-cancer effect & Osthole & $50 \mu \mathrm{mol} / \mathrm{L}$ & In vitro & [224] \\
\hline Anti-cancer effect & Osthole & $40,80,120$, and $160 \mu \mathrm{mol} / \mathrm{L}$ & In vitro & [225] \\
\hline Anti-cancer effect & Osthole & $\begin{array}{c}\text { For lung adenocarcinoma cell inhibition } \mathrm{IC}_{50} 81.3 \mu \mathrm{g} / \mathrm{L} \text {, } \\
\text { For liver cancer cell inhibition } \mathrm{IC}_{50} 134.8 \mu \mathrm{g} / \mathrm{L}\end{array}$ & In vitro & [226] \\
\hline Anti-cancer effect & Osthole & $0,50,100$, and $200 \mu \mathrm{M}$ & In vitro & [227] \\
\hline Anti-cancer effect & Osthole & 1,10 , and $30 \mu \mathrm{M}$ & In vitro & [228] \\
\hline Anti-cancer effect & Osthole & $100 \mathrm{mg} / \mathrm{kg}$ via intraperitoneal administration & In vivo & [229] \\
\hline Anti-cancer effect & Osthole & $0,50,100$, and $150 \mu \mathrm{M}$ & In vitro & [230] \\
\hline Anti-hepatotoxicity effect & Osthole & $\begin{array}{c}10 \mathrm{mg} / \mathrm{kg} \text { via gavage twice per day for } 4 \text { weeks, } \\
\qquad 1,3 \text {, and } 10 \mu \mathrm{g} / \mathrm{mL}\end{array}$ & In vivo+ In vitro & [231] \\
\hline Anti-cardiotoxicity effect & Osthole & $\begin{array}{c}5,10 \text {, and } 20 \mathrm{mg} / \mathrm{kg} \text { per day for } 16 \text { days via intraperitoneal } \\
\text { administration }\end{array}$ & In vivo & [232] \\
\hline Anti-neurotoxicity effect & Osthole & $0.01,0.05,0.1 \mathrm{mmol} / \mathrm{L}$ & In vitro & [233] \\
\hline Anti-idiopathic pulmonary fibrosis & Osthole & 1,10 , and $50 \mu \mathrm{mol} / \mathrm{L}$ & In vivo & [234] \\
\hline $\begin{array}{l}\text { Anti- focal segmental } \\
\text { glomerulosclerosis effect }\end{array}$ & Osthole & $\begin{array}{c}30 \mathrm{mg} / \mathrm{kg} \text { per day for } 7 \text { days and } 28 \text { days via intraperitoneal } \\
\text { injection }\end{array}$ & In vivo & [235] \\
\hline
\end{tabular}




\section{References}

1. Li, Y.M.; Jia, M.; Li, H.Q.; Zhang, N.D.; Wen, X.; Rahman, K.; Zhang, Q.Y.; Qin, L.P. Cnidium monnieri: A Review of Traditional Uses, Phytochemical and Ethnopharmacological Properties. Am. J. Chin. Med. 2015, 43, 835-877. [CrossRef]

2. Gao, F.; Hu, Y.; Ye, X.; Li, J.; Chen, Z.; Fan, G. Optimal extraction and fingerprint analysis of Cnidii fructus by accelerated solvent extraction and high performance liquid chromatographic analysis with photodiode array and mass spectrometry detections. Food Chem. 2013, 141, 1962-1971. [CrossRef] [PubMed]

3. Zhao, F.C.; Liao, S.Q.; Liang, Z.Q.; Zhi, X.; Zeng, Z. The Volatile Constitutes of Cnidium monnieri by GC/MS. J. Chin. Mass Spectrom. Soc. 2008, 29, 361-366.

4. Qiu, Q.; Cui, Z.; Liu, T.; Dong, Y. Determination of chemical constituents of the essential oil from Cnidium monnieri by GC-MS. J. Chin. Med. Mater. 2002, 25, 561.

5. Zhu, Y. Determination of chemical constituents of the essential oil from Cnidium by GC-MS. Li Shi Zhen Med. Mater. Med. Res. 2006, 10, 55.

6. Chen, Q.; Li, P.; Yuan, F.; Cheng, F.; He, J.; Liu, J.; Zhang, Z. Identification and quantification of the volatile constituents in Cnidium monnieri using supercritical fluid extraction followed by GC-MS. J. Sep. Sci. 2009, 32, 252-257. [CrossRef] [PubMed]

7. Osorio, C.; Duque, C.; Koami, T.; Fujimoto, Y. Stereochemistry of (3E)-3,7-dimethyl-3-octene-1,2,6,7-tetraol isolated from Passiflora quadrangularis. Tetrahedron Asymmetry 1999, 10, 4313-4319. [CrossRef]

8. Zhu, Y.; Gu, Y.H.; Zhu, L. Analysis of the Essential Oil from Cnidium monnieri in Two Different Producing Areas by GC-MS. China Pharm. 2008, 19, 2603-2605.

9. Wang, H.B.; Ge, F.H.; Li, J.; Huang, X.F.; Li, Y.; Hui, G.J.; Wu, H.Q.; Zhang, G.Y. Applied study of supercritical-CO2 fluid extraction in extracting volatile constituents of Cnidium monnieri seeds. China J. Chin. Mater. Med. 1996, 2, 18.

10. Buckingham, J. Dictionary of Natural Products; CRC Press: London, UK, 1993.

11. Meng, Z.M.; Jin, C.G.; Zhao, S.X. The GC-MS analysis of volatile oil of fructus Cnidii. J. Nanjing Coll. Pharm 1986, 17, 167.

12. Chen, Y.; Fan, G.; Zhang, Q.; Wu, H.; Wu, Y. Fingerprint analysis of the fruits of Cnidium monnieri extract by high-performance liquid chromatography-diode array detection-electrospray ionization tandem mass spectrometry. J. Pharm. Biomed. Anal. 2007, 43, 926-936. [CrossRef]

13. Zhou, Y.H.; Li, Y.L.; Wang, L.S. Analysis of chemical components of the essential oil from Fructus Cnidii. Guangxi Univ. Nat. Sci. Ed. 2005, 30, 263.

14. Zhao, L.H.; Shan, Z.; Li, X.J.; Xiang, B.R. Studies on fingerprints of Fructus cnidii by GC and GC-MS. Chin. Pharm. J. 2007, 42, 889-891.

15. Kim, S.B.; Ahn, J.H.; Han, S.B.; Hwang, B.Y.; Kim, S.Y.; Lee, M.K. Anti-adipogenic chromone glycosides from Cnidium monnieri fruits in 3T3-L1 cells. Bioorg. Med. Chem. Lett. 2012, 22, 6267-6271. [CrossRef] [PubMed]

16. Duan, X.H.; Zhang, Y.Z.; He, P.; Ma, Z.M.; Pi, L. Chomones from fruit of Cnidium monnieri and their effects on proliferation of UMR106 cells. Chin. Tradit. Herb. Drugs 2015, 46, 3310-3313.

17. Kimiye, B.; Hiromu, K.; Masahiko, T.; Mitsugi, K. Chormones from Cnidium monnieri. Phytochemistry 1992, 31, 1367-1370.

18. Cai, J.N.; Basnet, P.; Wang, Z.T.; Komatsu, K.; Xu, L.S.; Tani, T. Coumarins from the fruits of Cnidium monnieri. J. Nat. Prod. 2000, 63, 485-488. [CrossRef]

19. Yang, X.; Yang, S.P.; Zhang, X. Chromatographic fingerprint of Cnidium monnieri. Yao Xue Xue Bao 2007, 42, 877-881.

20. Kitajima, J.; Aoki, Y.; Ishikawa, T.; Tanaka, Y. Monoterpenoid glucosides of Cnidium monnieri fruit. Chem. Pharm. Bull. (Tokyo) 1999, 47, 639-642. [CrossRef]

21. Kitajima, J.; Aoki, Y.; Ishikawa, T.; Tanaka, Y. Monoterpenoid polyols in fruit of Cnidium monnieri. Chem. Pharm. Bull. (Tokyo) 1998, 46, 1580-1582. [CrossRef]

22. Kitajima, J.; Tanaka, Y. New monoterpenoid and hemiterpenoid tetraol of the crude drug 'She chuang $\mathrm{zi}^{\prime}$. Chem. Pharm. Bull. (Tokyo) 1993, 41, 1667-1669. [CrossRef] 
23. Oh, H.; Kim, J.S.; Song, E.K.; Cho, H.; Kim, D.H.; Park, S.E.; Lee, H.S.; Kim, Y.C. Sesquiterpenes with hepatoprotective activity from Cnidium monnieri on tacrine-induced cytotoxicity in Hep G2 cells. Planta Med. 2002, 68, 748-749. [CrossRef] [PubMed]

24. Kim, S.B.; Chang, B.Y.; Han, S.B.; Hwang, B.Y.; Kim, S.Y.; Lee, M.K. A new phenolic glycoside from Cnidium monnieri fruits. Nat. Prod. Res. 2013, 27, 1945-1948. [CrossRef] [PubMed]

25. Yahara, S.; Sugimura, C.; Nohara, T.; Niiho, Y.; Nakajima, Y.; Ito, H. Studies on the constituents of Cnidii monnieri Fructus. J. Pharmacogn. 1993, 47, 74-78.

26. Kitajima, J.; Ishikawa, T.; Aoki, Y. Glucides of Cnidium monnieri fruit. Phytochemistry 2001, 58, 641-644. [CrossRef]

27. Chen, Y.; Zhang, G.G.; Yu, Z.P. The advancement in the chemical and pharmacological study of the fruits of Cnidium monnieri. J. Shenyang Pharm. Univ. 2006, 23, 256-260.

28. Duan, Z.F.; Cheng, J.W.; Li, X. Research Status of Coumarins in Medicinal Plants of Umbelliferae and Their Pharmacological Effects. China Pharmacy 2008, 19, 223-226.

29. Jiang, T.; Li, H.L. Survey on studies on Cnidium monnieri. Chin. Tradit. Herb. Drugs 2001.

30. Duan, Y.D.; Jiang, Y.Y.; Guo, F.X.; Chen, L.X.; Xu, L.L.; Zhang, W.; Liu, B. The antitumor activity of naturally occurring chromones: A review. Fitoterapia 2019. [CrossRef]

31. Ludwiczuk, A.; Skalicka-Woźniak, K.; Georgiev, M.I. Chapter 11-Terpenoids. In Pharmacognosy; Badal, S., Delgoda, R., Eds.; Academic Press: Boston, MA, USA, 2017.

32. Bhagavan, N.V. CHAPTER 9-Simple Carbohydrates. In Medical Biochemistry, 4th ed.; Bhagavan, N.V., Ed.; Academic Press: San Diego, CA, USA, 2002.

33. Ji, Z.Q.; Zhang, J.M.; Xia, J.M.; Niu, G.D. Analysis of Liposoluble Constituents in Fruit of Cnidium Monnieri by GC-MS. China Pharm. 2015, 18, 1892-1894.

34. Zhu, Y.; Tan, R.L.; Wu, Z.Y.; Yu, D.J. Studies of Chemical Constituents of the Volatile Oil of Cnidii Fructus in Shandong. China Pharm. 2016, 25, 31-34.

35. Wang, W.L.; Yu, Z.M.; Ju, D.H.; Zhang, L.S.; Wang, Z.; Yang, L.X.; Zhao, H.X. Progress in chemistry and pharmacology of Cnidium. Chin. J. Basic Med. Tradit. Chin. Med. 2011, 17, 704-706.

36. Li, J.D.; Zhang, C.Z.; Wen, X.J.; Zhang, D.S.; Chen, L.F. Effect of osthole on the long-term potentiation of central nervous system in anesthetized rats. Shaanxi J. Tradit. Chin. Med. 2008, 29, 1083-1085.

37. Gong, Q.H.; Ding, L.J.; Wang, L.N.; Yang, D.L.; Shi, J.S. Osthole attenuates learning and memory deficits induced by lipopolysaccharide in rats. Chin. J. New Drugs Clin. Rem. 2011, 34, 335-337.

38. Liu, Y.G.; Li, X.H.; Deng, Y.Y.; Gong, Q.H. Osthole attenuates $\beta$-amyloid 25-35 induced neuronal injury through inhibition of nuclear factor-kappa B activation in rats. J. Zunyi Med. Univ. 2015, 38, 470-473.

39. Gong, Q.H.; Shi, J.S.; Yang, D.L. Osthole attenuates learning and memory deficits and neuronal ultrastructure in CA1 region of hippocampus induced by Abeta 25-35 fragment in rats. Acta Acad. Med. Zunyi 2011, 34, 335-338.

40. Dong, X.H.; Yu, X.Z.; Meng, X.Y.; Zhang, D.S.; Shen, L.X.; Li, W. Effects of osthole on neuron apoptosis of AD rats. Chin. Pharmacol. Bull. 2013, 29, 1282-1285.

41. Kumar, A.; Sharma, V.; Singh, V.P.; Kaundal, M.; Gupta, M.K.; Bariwal, J.; Deshmukh, R. Herbs to curb cyclic nucleotide phosphodiesterase and their potential role in Alzheimer's disease. Mech. Ageing Dev. 2015, 149, 75-87. [CrossRef]

42. Li, X.H.; Deng, Y.Y.; Shi, J.S.; Yang, D.L.; Yong, Q.H. Osthole ameliorates $\beta$-amyloid 25-35-induced neurotoxicity through decreasing the content of phosphodiesterase in rat model. J. Zunyi Med. Univ. 2015, 38, 359-362.

43. Yao, Y.J.; Hu, Y.; Li, S.H.; Jiao, Y.N.; Kong, L.; Tao, Z.Y.; Yang, J.X. Osthole promotes the proliferation of neural stem cells in vitro. Chin. J. Tissue Eng. Res. 2014, 18, 5184-5189.

44. Cheng, S.Y.; Chen, Y.B.; Wang, Q.; Liang, W.X.; Wen, Z.H. Effects of Osthole on Activation of Nuclear Factor-kappa B in Astrocytes Induced by Amyloid Protein Beta 25-35. J. Guangzhou Univ. Tradit. Chin. Med. 2010, 27, 36-39.

45. Jiao, Y.N.; Yao, Y.J.; Kong, L.; Li, S.H.; Tao, Z.Y.; Yan, Y.H.; Yang, J.X. Protective effect of osthole on SH-SY5Y cells transfected with APP595/596 gene. Chin. J. Pathophysiol. 2015, 31, 2053-2058. 
46. Li, S.H.; Jiao, Y.N.; Yao, Y.J.; Kong, L.; Tao, Z.Y.; Yan, Y.H.; Yang, J.X. Neuroprotective effect of osthole on neuron synapses infected APP gene. Chin. Pharmacol. Bull. 2015, 31, 1383-1388.

47. Yao, Y.; Gao, Z.; Liang, W.; Kong, L.; Jiao, Y.; Li, S.; Tao, Z.; Yan, Y.; Yang, J. Osthole promotes neuronal differentiation and inhibits apoptosis via Wnt/ $\beta$-catenin signaling in an Alzheimer's disease model. Toxicol. Appl. Pharmacol. 2015, 289, 474-481. [CrossRef] [PubMed]

48. Yan, Y.H.; Li, S.H.; Li, H.Y.; Lin, Y.; Yang, J.X. Osthole Protects Bone Marrow-Derived Neural Stem Cells from Oxidative Damage through PI3K/Akt-1 Pathway. Neurochem. Res. 2017, 42, 398-405. [CrossRef] [PubMed]

49. Wang, Y.Y.; Liang, X.C.; Wang, Y.M.; Li, X.L.; Shi, Y.; Lin, Y.; Yang, J.X. Enhancement of neural stem cell differentiation by miR-9 uplift. Pharmacol. Clin. Chin. Mater. Med. 2018, 34, 44-47.

50. Yao, Y.J.; Kong, L.; Jiao, Y.N.; Li, S.H.; Tao, Z.Y.; Yan, Y.H.; Yang, J.X. Osthole delays neural stem cells senescence induced by tert-butylhydroperoxide. Chin. J. Pharmacol. Toxicol. 2015, 29, 565-572.

51. Li, J.K.; Huang, J.W. Preliminary study on the protective mechanism of osthole on brain injury in rats with cerebral hemorrhage. Stud. Trace Elem. Health 2015, 32, 1-2.

52. Xie, H.T.; Shen, Y.; Zeng, C.Q. Effect of Osthole on Expressions of Caspase-3 and Caspase-9 Proteins in Hippocampal Neuron in Kainite- induced Rats. Inf. Tradit. Chin. Med. 2015, 32, 16-18.

53. Tong, F.Z.; Zeng, C.Q. Effect of Osthole on Puma Expression in Hippocampal Neurons of Rats with Kainate-induced Seizures. Chin. J. Tradit. Med. Sci. Technol. 2015, 22, 41-43.

54. Li, Z.Q.; Zou, F.F.; Zeng, C.Q.; Cui, J.H.; Li, X.Y.; Pan, X.; Duan, C.M. Effection of Osthole on Kv1.2 channel expression in epilepsy. J. Apoplexy Nerv. Dis. 2012, 29, 1094-1097.

55. Mao, X.Y.; Wang, Z.B.; Zhou, H.H.; Liu, Z.Q.; Zhou, Y. Osthole ameliorates glutamate-induced toxicity in HT22 cells via activating PI3K/Akt signaling pathway. J. Cent South. Univ. 2015, 40, 955-959.

56. Song, M.Q.; Feng, M.L.; Jia, L.L.; Wu, Y.P.; Niu, Y.Y.; Tong, L.G. Screening Extraction Process of Sedative-Hypnotic Ingredients in FructusCnidii. Shanxi J. Tradit. Chin. Med. 2010, 26, 36-38.

57. Song, M.Q.; Feng, M.L.; Jia, L.L.; Wu, Y.P.; Niu, Y.Y.; Tong, L.G. Research on sedation, hypnosis, hangover response, and tolerance of Fructus Cnidii. Medicine 2010, 25, 41-44.

58. Ma, L.; Tong, L.G.; Song, M.Q.; Hu, W.Z.; Jia, L.L.; Niu, Y.Y.; Zhong, Q.M.; Feng, M.L. Effects of Hypnotic Active Constituent of Cnidium monnieri on Sedation and Hypnosis, Learning and Memory, Hangover of Mice. China Pharm. 2016, 27, 4764-4767.

59. Wei, W.J.; Tong, L.G.; Zhong, Q.M.; Yang, Q.; Jia, L.L.; Hu, W.Z.; Song, M.Q.; Feng, M.L. Effects of hypnotic active components of Cnidii Fructus on expression of hippocampal Clock genes and amino acid neurotransmitters in PCPA insomnia rats. Chin. Tradit. Herb. Drugs 2018, 49, 2614-2619.

60. Du, Z.X.; Tang, P.Y.; Xie, W.J.; Pan, X.J.; Luo, W.C.; Chen, Q.Q.; Ou, C.R.; Liang, J.F.; Zhun, X.Q. Effect of osthole on memory function of sleep deprivation mice. J. Pract. Med. 2018, 34, 1633-1639.

61. Hou, X.B.; Mei, Q.S.; Yu, P.; Yan, Y.; Li, G.; Gui, C.; Chong, Z.; Qi, M.; Ma, L. Influence of Cnidii Fructus hypnotic active constituent on learning and memory of sleep-deprived rats. Chin. J. Tradit. Chin. Med. Pharm. 2015, 30, 837-840.

62. Liu, S.; Wu, D.Y.; Xu, J.H.; Guan, S.W.; Sun, D.W. Research of the anxiolytic effect of osthol. Chin. Med. Herald 2012, 9, 19-21. [CrossRef]

63. Wang, J.; Fu, Y.; Wei, Z.; He, X.; Shi, M.; Kou, J.; Zhou, E.; Liu, W.; Yang, Z.; Guo, C. Anti-asthmatic activity of osthole in an ovalbumin-induced asthma murine model. Respir. Physiol. Neurobiol. 2017, 239, 64-69. [CrossRef]

64. Xu, R.J.; Fan, Z.N. Effect of osthole on airway inflammation and remodeling in asthmatic rats. Asia-Pacif. Tradit. Med. 2016, 12, 29-30.

65. Chiu, P.R.; Lee, W.T.; Chu, Y.T.; Lee, M.S.; Jong, Y.J.; Hung, C.H. Effect of the Chinese herb extract osthol on IL-4-induced eotaxin expression in BEAS-2B cells. Pediatr. Neonatol. 2008, 49, 135-140. [CrossRef]

66. Qu, S.Y.; Ou, Y.; Hai, F.; Zhao, F.; Wu, Y.F.; Chen, J.; Wu, S.; Song, L.Q. Effect of osthole on asthmatic airway inflammation and mucus hypersecretion induced by ovalbumin in mice. Chin. J. Lung Dis. 2013, 6, 425-428.

67. Matsuda, H.; Tomohiro, N.; Ido, Y.; Kubo, M. Anti-allergic effects of cnidii monnieri fructus (dried fruits of Cnidium monnieri) and its major component, osthol. Biol. Pharm. Bull. 2002, 25, 809-812. [CrossRef] 
68. Kordulewska, N.K.; Kostyra, E.; Matysiewicz, M.; Cieślińska, A.; Jarmołowska, B. Impact of fexofenadine, osthole and histamine on peripheral blood mononuclear cell proliferation and cytokine secretion. Eur. J. Pharmacol. 2015, 761, 254-261. [CrossRef]

69. Wu, L.L.; Xu, X.Y. Experimental studies of fructus cnidii on fighting skin allergy. J. Mudanjiang Med. Univ. 2011, 32, 9-10.

70. Kordulewska, N.K.; Kostyra, E.; Cieślińska, A.; Fiedorowicz, E.; Jarmołowska, B. Cytokine production by PBMC and serum from allergic and non-allergic subjects following in vitro histamine stimulation to test fexofenadine and osthole anti-allergic properties. Eur. J. Pharmacol. 2016, 791, 763-772. [CrossRef]

71. Tanabe, H.; Yasui, T.; Kotani, H.; Nagatsu, A.; Makishima, M.; Amagaya, S.; Inoue, M. Retinoic acid receptor agonist activity of naturally occurring diterpenes. Bioorg. Med. Chem. 2014, 22, 3204-3212. [CrossRef]

72. Zhang, Y.; Sun, S.X.; Ma, W.; Li, C.Y.; Wang, B.; Wang, Z.X.; Kang, X.; Ji, Z. Effect of Osthole on carotid intimal hyperplasia in rats. Chin. J. Mod. Med. 2018, 28, 21-25.

73. Zhong, W.; Zhou, F.; Xue, J.; Xie, M.L. Experimental Study of Osthole on Inhibiting Atherosclerotic Formation in Rats. J. Soochow Univ. 2011, 31, 735-739.

74. Zhang, Y.; Xie, T.; Xue, J.; Zhu, L.J.; Hua, Y.N.; Xie, M.L.; Gu, Z.L. Study of the effects of osthole on blood estradiol and lipase in animals and their relationship. Chin. Pharmacol. Bull. 2007, 23, 1476-1480.

75. Zhang, Y.; Sun, S.X.; Ma, W.; Li, C.Y.; Wang, B.; Wang, Z.X.; Kang, X.L.; Ji, Z. Protective effects of osthole on ox-LDL-induced-apoptosis of human umbilical vein endothelial cells via Akt/eNOS. Pharmacol. Clin. Chin. Mater. Med. 2017, 33, 60-63.

76. Liu, J.C.; Zhou, L.; Wang, F.; Cheng, Z.Q.; Rong, C. Osthole decreases collagen I/III contents and their ratio in TGF- $\beta 1$-overexpressed mouse cardiac fibroblasts through regulating the TGF- $\beta /$ Smad signaling pathway. Chin. J. Nat. Med. 2018, 16, 321-329. [CrossRef]

77. Quan, Y.; Meng, Q.H.; Liu, J.L. Protective effect of total coumarines from the fruits of Cnidium monnieri on mitochondrial dynamics in rat myocardial infarction model. Northwest Pharm. J. 2018, 33, 189-192.

78. Yang, X.; Zeng, X.J.; Li, Y. Osthole attenuated myocardial ischemia/reperfusion by suppressing apoptosis via a mitochondrial pathway. J. Clin. Cardiol. 2016, 32, 517-521.

79. Li, S.J.; Li, C.G. Role of PI3K/AKT signaling pathway in osthole-preconditioning myocardium in rats. Chin. J. Hosp. Pharm. 2014, 34, 371-374.

80. Ma, T.Q.; Yan, Z.; Wen, Y.J.; Cao, C.Z.; Ma, W.L.; Liang, F. Effects of osthole postconditioning on cardiomyocyte apoptosis induced by acute ischemia/reperfusion in rats and the possible mechanism. Chin. J. Clin. 2012, 6, 6737-6740.

81. Li, Y.L.; Wang, Y.W.; Li, Y.Q.; Wang, J.Y.; Yang, D.L. Osthole could attenuate right ventricle remodeling in monocrotaline-treated rats by up-regulating PPAR $\alpha$ and PPAR $\gamma$. Chin. Pharm. Bull. 2015, 31, 1270-1272.

82. Li, Y.L.; Wang, Y.W.; Li, L.S.; Hua, L.; Yang, D.L. Osthole reverses pulmonary artery remodeling induced by monocrotaline through increasing expression of p53 and reducing the expression of proliferating cell nuclear antigen and Ki67. Chin. J. New Drugs Clin. Rem. 2015, 34, 773-777.

83. Xu, Z.X.; Zheng, X.; Zhu, L. Effect of osthole on sodium channels of ventricular myocytes in rat. J. Clin. Med. Pract. 2016, 20,1-5.

84. Yuan, C.H.; Li, B.X.; Sun, L.R.; Zhu, X.H. Effect of Osthole on L-and N-type Calcium Channels. Prog. Mod. Biomed. 2011, 11, 2806-2809.

85. Li, S.J.; Yuan, C.H. Effect of osthole on potassium channels of cadiocytes in neonate rats in vitro. J. Xinxiang Med. Coll. 2011, 28, 414-417.

86. He, G.H.; Teng, Z.X.; Yao, L. Effect of Osthole on Isolated Pulmonary Arteries. Nat. Prod. Res. Dev. 2015, 27, 986-989.

87. Zhou, N.; He, J.Y.; Wang, T.; Zhang, J.; He, H.Z. Design, synthesis, and vasorelaxation activity of novel imperatorin derivatives. J. Asian Nat. Prod. Res. 2013, 15, 650-657. [CrossRef] [PubMed]

88. Zhang, Y.; Cao, Y.; Zhan, Y.; Duan, H.; He, L. Furanocoumarins-imperatorin inhibits myocardial hypertrophy both in vitro and in vivo. Fitoterapia 2010, 81, 1188-1195. [CrossRef]

89. Ogawa, H.; Sasai, N.; Kamisako, T.; Baba, K. Effects of osthol on blood pressure and lipid metabolism in stroke-prone spontaneously hypertensive rats. J. Ethnopharmacol. 2007, 112, 26-31. [CrossRef] 
90. Cao, Y.J.; He, X.; Wang, N.; He, L.C. Effects of imperatorin, the active component from Radix Angelicae (Baizhi), on the blood pressure and oxidative stress in 2K,1C hypertensive rats. Phytomedicine 2013, 20, 1048-1054. [CrossRef]

91. Zhang, Y.; Cao, Y.; Wang, Q.; Zheng, L.; Zhang, J.; He, L. A potential calcium antagonist and its antihypertensive effects. Fitoterapia 2011, 82, 988-996. [CrossRef]

92. Zhang, Y.; Wang, Q.L.; Zhan, Y.Z.; Duan, H.J.; Cao, Y.J.; He, L.C. Role of store-operated calcium entry in imperatorin-induced vasodilatation of rat small mesenteric artery. Eur. J. Pharmacol. 2010, 647, 126-131. [CrossRef]

93. Zhang, D.; Zhang, K.Q.; Liu, S.M. Vasorelaxation of Rat Thoracic Aorta Caused by Osthole. J. Sichuan Tradit. Chin. Med. 2016, 34, 51-54.

94. Zhang, J.; Wang, J.; Wang, F. Protective effect of Osthole in renal ischemia-reperfusion injury in rats. Acta Univ. Med. Anhui 2018, 53, 1731-1736.

95. Zhao, B.Q.; Liu, J.H. Effect of osthole on renal ischemia reperfusion injury. Pract. Pharm. Clin. Rem. 2017, 20, 11-14.

96. Xie, D.Q.; Zhang, C.L.; Wu, Y.L. Osthole Precondition Protected Rats Against Renal Ischemia- reperfusion Injury by Suppressing Inflammation. Chin. J. Integr. Tradit. West. Nephrol. 2015, 16, 102-105.

97. Ding, X.; Liu, H.; Wang, P. Protective Effect of Osthole on Retina Ischemia Reperfusion Injury in Rats. Pharmaceut. J. Chin. People's Lib. Army 2016, 32, 311-317.

98. Ge, P.; Yang, B.; Li, X.F.; Zhou, L.; Jing, R.J.; Li, H.J.; Jiang, T. Lung Protection of Osthole Against Intestinal Ischemia-Reperfusion Lung Injury in Rats. Prog. Mod. Biomed. 2013, 13, 5401-5404.

99. Mo, L.Q.; Chen, Y.; Song, L.; Wu, G.M.; Tang, N.; Zhang, Y.Y.; Wang, X.B.; Liu, K.X.; Zhou, J. Osthole prevents intestinal ischemia-reperfusion-induced lung injury in a rodent model. J. Surg. Res. 2014, 189, 285-294. [CrossRef]

100. Ma, T.Q.; Liang, Z.X. Protective Effect of Osthole Injection on Donor Heart in Canine Orthotopic Heart Transplantation. Chin. J. Integr. Med. Cardio-/Cerebrovascular Dis. 2008, 6, 48-51.

101. Wang, J.; Zhang, J. Osthole alleviates cerebral ischemia-reperfusion injury by suppressing mitochondrial mediating apoptosis. J. Xi'an Jiao Tong Univ. 2017, 38, 131-135.

102. Zhao, Y.M.; Wang, J.; Shi, H.; Liu, H.B.; Zheng, L.Q.; Dong, X.H. Protective Effects of Osthole on Rats with Focal Cerebral Ischemia-reperfusion Injury. Her. Med. 2014, 33, 1558-1561.

103. Guan, J.; Wei, X.; Qu, S.; Lv, T.; Fu, Q.; Yuan, Y. Osthole prevents cerebral ischemia-reperfusion injury via the Notch signaling pathway. Biochem. Cell Biol. 2017, 95, 459-467. [CrossRef]

104. Mao, X.; Yin, W.; Liu, M.; Ye, M.; Liu, P.; Liu, J.; Lian, Q.; Xu, S.; Pi, R. Osthole, a natural coumarin, improves neurobehavioral functions and reduces infarct volume and matrix metalloproteinase-9 activity after transient focal cerebral ischemia in rats. Brain Res. 2011, 1385, 275-280. [CrossRef] [PubMed]

105. Dong, X.H.; Zhang, D.S.; Zhang, L.; Li, W. Effects of osthole on LTP and contents of amino acid in hippocampus of cerebral ischemia-reperfusion rats. Chin. Pharmacol. Bull. 2011, 27, 1267-1271.

106. He, W.; Lian, Q.S.; Liu, J.X. Protective effects of osthole on focal cerebral ischemia-reperfusion injury in rats. Chin. Tradit. Herb. Drugs 2009, 24, 1528-1530.

107. He, W.; Liu, J.X.; Zhou, Y.M.; Zhou, L.; Zhou, Q.; Ye, H.Y.; Lian, Q.S. Protective effects of Osthole on cerebral ischemia-reperfusion injury in rats and its mechanism. Chin. Pharmacol. Bull. 2008, 24, 1528-1530.

108. Chen, R.; Xie, M.L. Effects of osthole on antithrombosis and its mechanisms. Mod. Med. J. Chin. 2008, $10,50-52$.

109. Cheng, R.; Xie, M.L. Effects of osthole on the concentration of intracellular free calcium and the expression of inositol triphosphate receptor-3 in human platelets. Jiangsu J. Tradit. Chin. Med. 2009, 41, 78-79.

110. Wu, H.X.; Feng, L.L.; Xu, H.; He, Q.L.; Li, M.N.; Wei, M.; Sun, L.B.; Zou, X.N. Effect of osthole on ERK /MAPK signaling pathway and the expression of COX-2 mRNA in the spinal dorsal horn of rats with nucleus pulposus-induced inflammatory radicular pain. Chin. Pharmacol. Bull. 2014, 30, 1096-1101.

111. Wei, M.; Zhang, J.J.; He, Q.L.; Wang, L.; Ren, Z.H.; Sun, L.B.; Liu, X.G. Effects and Mechanisms of Osthole on Sciatica Induced by Lumber Disc Herniation. Zhong Yao Cai 2011, 34, 746-750. 
112. Wu, H.X.; Feng, L.L.; He, Q.L.; Wei, M.; Xu, H.; Li, M.N.; Sun, L.B.; Zou, X.N. Effect of osthole on expression of CGRPR1 in DRG of rats with nucleus pulposus-induced sciatica. Chin. Pharmacol. Bull. 2014, 30, 49-54.

113. Jian, W.Z.; Shi, Y.C.; Jing, L.; Jiao, J.W.; Ke, P.P.; Jing, Z.; Shou, C.W.; Chuan, W.; Zheng, H.W.; Xu, W.L. Effects of Cnidium monnieri (L.)cussonon compound action potential of sciatic nerve of toad. Sichuan J. Physiol. Sci. 2014, 36, 58-59.

114. He, Q.L.; Wei, M.; Li, M.N.; Xu, H.; Zou, X.N.; Sun, L.B. Osthole inhibited the acid-evoked change of membrane potential of rats dorsal root ganglia neuron following application of nucleus pulposus. Chin. Pharmacol. Bull. 2010, 26, 1459-1462.

115. Zhang, J.J.; Xie, M.L.; Wang, H.B. Therapeutic Effect of Osthole on Alcohol-Indced Fatty Liver in Mice. J. Soochow Univ. 2011, 31, 62-65.

116. Du, R.; Xue, J.; Wang, H.B.; Zhang, Y.; Xie, M.L. Osthol ameliorates fat milk-induced fatty liver in mice by regulation of hepatic sterol regulatory element-binding protein-1c/2-mediated target gene expression. Eur. J. Pharmacol. 2011, 666, 183-188. [CrossRef]

117. Sun, F.; Xie, M.L.; Zhu, L.J.; Xue, J.; Gu, Z.L. Inhibitory effect of osthole on alcohol-induced fatty liver in mice. Dig. Liver Dis. 2009, 41, 127-133. [CrossRef] [PubMed]

118. Shen, H.; Zhou, F.; Xue, J.; Xie, M.L. Osthole regulates fatty acid metabolism in hepatocytes by activation of PPAR $\alpha$. Chin. J. Pharm. Toxicol. 2013, 27, 174-179.

119. Sun, F.; Xie, M.L.; Xue, J.; Wang, H.B. Osthol regulates hepatic PPAR $\alpha$-mediated lipogenic gene expression in alcoholic fatty liver murine. Phytomedicine 2010, 17, 669-673. [CrossRef]

120. Khairy, H.; Saleh, H.; Badr, A.M.; Marie, M.A.S. Therapeutic efficacy of osthole against dinitrobenzene sulphonic acid induced-colitis in rats. Biomed. Pharmacother. 2018, 100, 42-51. [CrossRef]

121. Tao, Z.Y.; Kong, L.; Yao, Y.J.; Jiao, Y.N.; Li, S.H.; Yan, Y.H.; Yang, J.X. Therapeutic effects of osthole in mice following stab wound injury. Chin. J. New Drugs 2016, 25, 589-594.

122. Kong, L.; Yao, Y.J.; Jiao, Y.N.; Li, S.H.; Tao, Z.Y.; Yan, Y.H.; Yang, J.X. Anti-apoptosis and anti-inflammatory effect of osthole in mice following stab wound injury. Chin. Pharm. Bull. 2015, 31, 999-1003.

123. Li, H.Z.; Wang, Y.H.; Fang, S.B.; Gao, L.; Chai, Z.; Zhou, R. Experimental Research of Cnidium Lactone Microemulsion on the Anti- inflammatory Effect. World J. Integr. Tradit. West. Med. 2015, 10, 1077-1082.

124. Chao, L.K.; Lin, C.H.; Chiu, H.W.; Wong, W.T.; Chiu, H.W.; Tasi, Y.L.; Kuo, Y.H.; Chiu, Y.C.; Liu, M.L.; Ho, C.L.; et al. Peroxyauraptenol Inhibits Inflammation and NLRP3 Inflammasome Activation by Inhibiting Reactive Oxygen Species Generation and Preserving Mitochondrial Integrity. J. Agric. Food Chem. 2015, 63, 1210-1219. [CrossRef] [PubMed]

125. Ang, X.; Zeng, X.J.; Fu, J. Protective effect of osthole on LPS-induced acute lung injury in mice and its mechanism. Pract. Pharm. Clin. Remed. 2015, 18, 893-896.

126. Zhao, J.Y.; Fei, X.; Yue, Q.; Guo, H.; Deng, C.Q.; Hao, J.H. The protective effect of Osthole in rats with sepsis-induced acute lung injury. Chin. Med. Herald 2013, 10, 103-107.

127. Bao, Y.; Meng, X.; Liu, F.; Wang, F.; Yang, J.; Wang, H.; Xie, G. Protective effects of osthole against inflammation induced by lipopolysaccharide in BV2 cells. Mol. Med. Rep. 2018, 17, 4561-4566. [CrossRef]

128. Yu, P.X.; Yu, W.Y.; Kan, W.J.; Li, M.M.; Song, J.S.; Zhao, F. Anti-inflammatory effect and mechanism of osthole. Lishizhen Med. Mater. Med. Res. 2012, 23, 866-867.

129. Liao, P.C.; Chien, S.C.; Ho, C.L.; Wang, E.I.; Lee, S.C.; Kuo, Y.H.; Jeyashoke, N.; Chen, J.; Dong, W.C.; Chao, L.K.; et al. Osthole regulates inflammatory mediator expression through modulating NF-kappaB, mitogen-activated protein kinases, protein kinase C, and reactive oxygen species. J. Agric. Food Chem. 2010, 58, 10445-10451. [CrossRef]

130. Lee, T.H.; Chen, Y.C.; Hwang, T.L.; Shu, C.W.; Sung, P.J.; Lim, Y.P.; Kuo, W.L.; Chen, J.J. New isoflavones and anti-inflammatory constituents from the fruits of Cnidium monnieri. Int. J. Mol. Sci. 2014, 15, 9566-9578. [CrossRef]

131. Hanawa, M.A.; Asano, T.; Akiyama, K.; Yabe, K.; Tsunoda, K.; Tadano, T.; Sutoo, D.E. Effect of Zena F-III ${ }^{\circledR}$, a Liquid Nutritive and Tonic Drug, on the Neurochemical Changes Elicited by Physical Fatigue in Mice. Pharmacol. Biochem. Behav. 2000, 66, 771-778. [CrossRef] 
132. Deng, Y.X.; Cao, J.M.; Zhou, H.T.; Zheng, M.J. Effect of Fructus cnidii on Testosterone Content, Substance Metabolism and Exercise Capacity in Rats Receiving Exercise Training. Chin. J. Exp. Tradit. Med. Formulae 2013, 19, 262-265.

133. Tan, X.H.; Tian, J.M.; Zhao, J.L.; Zhang, D.S. Antioxidant activity of osthole in vitro. Chin. Tradit. Pat. Med. 2013, 35, 1070-1073.

134. Zhao, J.H.; Zhang, F.; Guo, N.; Zhang, Y.L.; Guo, J. Study on inhibiting effect of alcohol extract from common cnidium fruit on Escherichia coli. J. Zhoukou Normal Univ. 2017, 34, 102-104.

135. Joshi, P.; Singh, S.; Wani, A.; Sharma, S.; Jain, S.K.; Singh, B.; Gupta, B.D.; Satti, N.K.; Koul, S.; Khan, I.A.; et al. Osthol and curcumin as inhibitors of human Pgp and multidrug efflux pumps of Staphylococcus aureus: Reversing the resistance against frontline antibacterial drugs. MedChem Comm 2014, 5, 1540-1547. [CrossRef]

136. Feng, F.; Yang, J.H.; Zhang, J.W. Study on the Anti-Ureaplasma Urealyticum Effect of Fructus Cnidii Extract. Lishizhen Med. Mater. Med. Res. 2008, 19, 2105.

137. Guo, X.L.; Zhu, S.C.; Zhang, C.; Wang, H.Y.; Bao, L. Study on Combined Antibacterial Activities of Matrine, Oxymatrine and Cnidium Monnieri(L.) Cusson. Chin. Arch. Tradit. Chin. Med. 2011, 29, 1398-1400.

138. Fu, T.T.; Wu, J.Y.; Wang, L.; Ma, Y.; Wang, Y.; Liu, Y.; Ding, H. Study on the Chinese herbal formula for treatment of vaginitis and the antimicrobial activity in murine models. J. Chin. Med. Mater. 2006, 29, 931-936.

139. Malla, B.; Chang, B.Y.; Kim, S.B.; Park, H.; Lee, M.K.; Kim, S.Y. Potential of the Cnidium monnieri fruits as an immune enhancer in Escherichia coli infection model. J. Pharm. Pharmacol. 2016, 68, 1430-1439. [CrossRef] [PubMed]

140. Tamura, S.; Fujitani, T.; Kaneko, M.; Murakami, N. Prenylcoumarin with Rev-export inhibitory activity from Cnidii Monnieris Fructus. Bioorg. Med. Chem. Lett. 2010, 20, 3717-3720. [CrossRef]

141. Deng, J.H.; Wang, G.S.; Ma, Y.H.; Shi, M.; Li, B. Antifungal effect of extracts of 32 traditional Chinese herbs against intestinal Candida in vitro. World Chin. J. Digestol. 2010, 18, 741-743. [CrossRef]

142. Li, D.D.; Chai, D.; Huang, X.W.; Guan, S.X.; Du, J.; Zhang, H.Y.; Sun, Y.; Jiang, Y.Y. Potent in vitro synergism of fluconazole and osthole against fluconazole-resistant Candida albicans. Antimicrob. Agents Chemother. 2017, 61. [CrossRef]

143. Zhang, R.R.; Liu, J.; Zhang, Y.; Hou, M.Q.; Zhang, M.Z.; Zhou, F.; Zhang, W.H. Microwave-assisted synthesis and antifungal activity of novel coumarin derivatives: Pyrano[3,2-c]chromene-2,5-diones. Eur. J. Med. Chem. 2016, 116, 76-83. [CrossRef]

144. Lan, S.M.; Mei, Q.H.; Lin, J.M.; Gong, W.F.; Lin, M.R. Effect on superficial mycosis of the integrality of Osthole's lactonic ring. Chin. Med. Herald 2010, 7, 20-21.

145. Yuan, M.; Luo, Y.; Xin, Q.; Gao, H.; Zhang, G.; Jing, T. Efficacy of osthole for Echinococcus granulosus in vitro and Echinococcus multilocularis in vivo. Vet. Parasitol. 2016, 226, 38-43. [CrossRef] [PubMed]

146. Li, W.C.; Gu, Y.F.; Liu, C.; Wu, N.; Luo, W.W.; Gong, P.T.; Li, H.; Li, J.H.; Zhang, X.C. In Vitro Effect of Osthole on Ultrastructure of Giardia lamblia. Chin. J. Parasitol. Parasit. Dis. 2014, 32, 242-244.

147. Wang, Z.; Kim, J.R.; Wang, M.; Shu, S.; Ahn, Y.J. Larvicidal activity of Cnidium monnieri fruit coumarins and structurally related compounds against insecticide-susceptible and insecticide-resistant Culex pipiens pallens and Aedes aegypti. Pest. Manag. Sci. 2012, 68, 1041-1047. [CrossRef]

148. Xia, M.L.; Duan, L.F.; Xu, J.T.; He, G.M.; Huang, L.; Wu, J.; Chen, X.Y. An in vitro test of killing effect of osthol against Trichomonas vaginalis. Chin. Trop. Med. 2008, 8, 388-389.

149. Liu, C.; Wu, N.; Tian, T.; Gong, P.T.; Li, J.H.; Zhang, X.C. The effects of osthole on Giardia canis in vitro. J. Path. Biol. 2013, 8, 1014-1016.

150. Yuan, H.; Ouyang, S.; Yang, R.; Li, S.; Gong, Y.; Zou, L.; Jia, T.; Zhao, S.; Wu, B.; Yi, Z.; et al. Osthole alleviated diabetic neuropathic pain mediated by the P2X4 receptor in dorsal root ganglia. Brain Res. Bull. 2018, 142, 289-296. [CrossRef]

151. Mao, X.Y.; Zhou, H.H.; Liu, Z.Q. Osthole alleviates the inflammation in rats with diabetes-associated cognitive decline via inhibiting PI3K/Akt signaling pathway. Chin. J. Gerontol. 2015, 35, 4743-4746.

152. Fang, M.J.; Wang, Y.; Hu, X.M.; Wu, G.J.; Zhao, X.; Xu, Y.C. Protective Effect of Osthole on Injury Induced by Palmitic Acid in Pancreatic Beta Cells. Med. J. Wuhan Univ. 2018, 35, 4743-4746.

153. Zhu, S.H.; Liu, X.Q.; Jiang, H.D.; Zheng, C.R.; Zhan, Y.T.; Liang, S.D.; Li, G.L. Effects of osthole on human umbilical vein endothelial cells injury induced by high glucose. Chin. Tradit. Patent Med. 2015, 37, 929-934. 
154. Alabi, O.D.; Gunnink, S.M.; Kuiper, B.D.; Kerk, S.A.; Braun, E.; Louters, L.L. Osthole activates glucose uptake but blocks full activation in L929 fibroblast cells, and inhibits uptake in HCLE cells. Life Sci. 2014, 102, 105-110. [CrossRef] [PubMed]

155. Qin, L.P.; Zhang, H.M.; Zhang, W.D. Effect of osthol and total coumarins of fructus cnidii on thyroid hormone and thyrotropic hormone in kidney-yang deficiency rats. Chin. J. Integr. Med. 1996, 16, 552-553.

156. Zhang, X.W.; Zhang, D.S.; Xue, G.P.; Zhao, Y.J.; Jin, C. Experimental research on estrogenic effect of Osthole on rats. Chin. Pharm. Bull. 2013, 29, 1031-1032.

157. Hou, X.H.; Cao, B.; Liu, H.Q.; Wang, Y.Z.; Bai, S.F.; Chen, H. Effects of osthole on apoptosis and TGF-beta1 of hypertrophic scar fibroblasts. J. Asian Nat. Prod. Res. 2009, 11, 663-669. [CrossRef] [PubMed]

158. Hou, X.H.; Cao, B.; Chen, S.W.; Chen, H. Study of osthole inhibiting NIH3T3 growth. Tianjin Pharm. 2008, 20,5-9.

159. Hou, X.H.; Chen, H.; Cao, B. Effects of osthole on fibroblast proliferation and transforming growth factor beta 1 expression in hypertrophic scar tissue. J. Clin. Rehabil. Tissue Eng. Res. 2011, 15, 7681-7684.

160. Wang, K.; Yuan, Z.T.; Wang, J.H.; Zhao, Z.H. Effect of osthole on the proliferation and apoptosis of HaCaT cells. Mod. Med. J. Chin. 2009, 11, 53-55.

161. Tse, W.P.; Che, C.T.; Liu, K.; Lin, Z.X. Evaluation of the anti-proliferative properties of selected psoriasis-treating Chinese medicines on cultured HaCaT cells. J. Ethnopharmacol. 2006, 108, 133-141. [CrossRef]

162. Xiong, J.; Zhong, Z.D.; Fu, R.; Xiong, W. Effect of Osthole on Mast Cells and Expression of STAT5 Gene and Protein in Mice with Eczema. Herald Med. 2015, 34, 1584-1587.

163. Luo, Y.H.; Gao, Z.M.; Liang, X.Y.; Fu, K.; Lei, D.X.; Wu, X.D.; Nie, H. Antipruritic Effects and Primary Mechanism of Osthole. Chin. Pharm. 2014, 25, 1750-1753.

164. Wang, Y.H.; Fang, S.B.; Gao, L.; Chai, Z.; Zhou, R. Experimental Study on Anti-pruritic and Anti-allergic TypeIV Effects of Osthole Microemulsion in Animal Models. Chin. Arch. Tradit. Chin. Med. 2014, 32, 1932-1934.

165. Wang, Q.; Zhang, Y.; Mao, H.J.; Wang, J.P.; Jia, R.R.; Jin, L.F.; Dai, Z.R. Study on anti-itching effective ingredients in Cnidium monnieri (L.) Cusson. J. Southern Med. Univ. 2009, 12, 2567-2569.

166. Matsuda, H.; Ido, Y.; Hirata, A.; Ino, Y.; Naruto, S.; Amamiya, T.; Kubo, M. Antipruritic effect of Cnidii Monnieri Fructus (fruits of Cnidium monnieri CUSSON). Biol. Pharm. Bull. 2002, 25, 260-263. [CrossRef] [PubMed]

167. Xie, H.; Li, Q.N.; Huang, L.F.; Wu, T. Effect of total coumarins from dried fruits of Cnidium monnieri on glucocorticoid-induced osteoporosis in rats. Zhongguo Yao Li Xue Bao 1994, 15, 371-374.

168. Luo, X.L.; Liang, X.P.; Wen, J.L. Effect of Cnidium monnier (L.) Cusson on Bone Mineral Density and Trabecular Area in Experimental Osteoporosis Rats. J. Emerg. Tradit. Chin. Med. 2008, 17, 368-369.

169. Jia, M.; Li, Y.; Xin, H.L.; Hou, T.T.; Zhang, N.D.; Xu, H.T.; Zhang, Q.Y.; Qin, L.P. Estrogenic activity of osthole and imperatorin in MCF-7 cells and their osteoblastic effects in Saos-2 cells. Chin. J. Nat. Med. 2016, 14, 413-420. [CrossRef]

170. Li, C.Y.; Wu, T.; Li, Q.N.; Lin, B.Y.; Liang, N.C.; Huang, L.F.; Cui, L. Quantitative study on the effect of osthole on proximal tibiae in ovariectomized(OVX) rats. Yaо Xue Xue Bao 1996, 31, 327-332.

171. Ji, H.; Liu, Y.; Lu, Y.R. Studies on effects of compound GYB on osteoporosis rats induced by retinoic acid. Chin. J. Nat. Med. 2005, 3, 56-59.

172. Wang, Q.; Zhang, Y.; Mao, H.J.; Wang, J.P.; Jia, R.R.; Jin, L.F.; Dai, Z.R. Effect of osthole on tricalcium phosphate particles-induced calvarial osteolysis in a mouse model. Chin. J. Pathophysiol. 2015, 31, 2265-2270.

173. Zhang, Z.R.; Leung, W.N.; Li, G.; Kong, S.K.; Lu, X.; Wong, Y.M.; Chan, C.W. Osthole enhances osteogenesis in osteoblasts by elevating transcription factor osterix via cAMP/CREB signaling in vitro and in vivo. Nutrients 2017, 9, 558. [CrossRef]

174. Wang, Y.; Pan, Y.M. Effect of Osthol on the Expressions of OPG and RANKL mRNA in Calvarium Osteoblasts of New Born Rats. J. Shanxi College Tradit. Chin. Med. 2008, 9, 12-14.

175. Ming, L.G.; Ge, B.F.; Chen, K.M.; Ma, H.P.; Zhai, Y.K. Effects of osthol on bone marrow stromal stem cell differentiation and proliferation in vitro. Chin. Pharm. Bull. 2010, 26, 1098-1103.

176. Dao, F.D.; Song, P.W.; Xiao, F.L.; Xiao, G.Z.; Hong, S.Z.; Tie, 1.D.; Yue, L.C. Inhibition effect of osthole on proliferation of rat chondrocytes. J. Chin. Integr. Med. 2012, 10, 1413-1418. 
177. Ma, Y.; Guo, Y.; Yuan, T.; Lu, J.S.; Liu, S.K.; Wang, P.M. Effect of bone-targeted osthole on rat osteoblast proliferation in vitro. Chin. J. Osteoporosis 2012, 18, 781-784.

178. Li, L.H.; Ding, D.F.; Du, G.Q.; Gong, H.; Wang, H.H.; Zhan, H.S. Effect of osthole on proliferation of neonatal rat osteoblast and the relative mechanism research. Zhongguo Gu Shang 2013, 26, 419-422. [PubMed]

179. Zhou, J.; Ge, B.F.; Zhen, P.; Ma, X.N.; Yan, L.J.; Guo, X.Y.; Cheng, K.; Gao, Y.H.; Shi, W.G.; Chen, K.M. Effect of Osthole on Bone Metabolism in Rat Femoral Tissues In Vitro. Chin. J. Orthop. Trauma 2013, 28, 832-837.

180. Wang, L.N.; Ma, Y.; Zheng, S.Y.; Guo, Y.; Pan, Y.L.; Wang, L.; Gu, M.; Sun, J. Effect of osthole on osteoclast differentiation and gene expression of NFATc1. Chin. J. Osteoporosis Bone Miner. Res. 2018, 11, 475-482.

181. Zheng, S.Y.; Guo, Y.; Ma, Y.; Wang, L.N.; Pan, Y.L. Effects of osthol loaded chitosan derivative micelles on osteoblasts based on BMP signaling. Chin. J. Tradit. Chin. Med. Pharm. 2018, 33, 4929-4932.

182. Ming, L.G.; Zhou, J.; Cheng, G.Z.; Ma, H.P.; Chen, K.M. Osthol, a coumarin isolated from common cnidium fruit, enhances the differentiation and maturation of osteoblasts in vitro. Pharmacology 2011, 88, 33-43. [CrossRef] [PubMed]

183. Huang, Y.; Bo, Y.; Wu, X.; Wang, Q.; Qin, F.; Zhao, L.; Xiong, Z. An intergated serum and urinary metabonomic research based on UPLC-MS and therapeutic effects of Gushudan on prednisolone-induced osteoporosis rats. J. Chromatogr. B 2016, 1027, 119-130. [CrossRef] [PubMed]

184. Zhang, Z.; Leung, W.N.; Li, G.; Lai, Y.M.; Chan, C.W. Osthole Promotes Endochondral Ossification and Accelerates Fracture Healing in Mice. Calcif. Tissue Int. 2016, 99, 649-660. [CrossRef] [PubMed]

185. Xu, H.; Wu, T.; Xu, B.L.; Dian, L.H. Effects of total flavonoids from dried fruits of cnidium monnieri on femora bone mineral density and bone biomechanical character of in ovariectomize rats. Mod. Med. J. Chin. 2009, 11, 28-30.

186. Lv, S.; Zhang, Y.; Yan, M.; Mao, H.; Pan, C.; Gan, M.; Fan, J.; Wang, G. Inhibition of osteolysis after local administration of osthole in a TCP particles-induced osteolysis model. Int. Orthop. 2016, 40, 1545-1552. [CrossRef] [PubMed]

187. Gao, L.N.; An, Y.; Lei, M.; Li, B.; Yang, H.; Lu, H.; Chen, F.M.; Jin, Y. The effect of the coumarin-like derivative osthole on the osteogenic properties of human periodontal ligament and jaw bone marrow mesenchymal stem cell sheets. Biomaterials 2013, 34, 9937-9951. [CrossRef]

188. Zhu, Y.S.; Song, W.; Zhao, Y.; Huang, P.; Hao, C.Y.; Yang, H.B. Study on the induced apoptosis of cholangiocarcinoma QBC939 cells by Osthole. Guangdong Med. J. 2018, 39, 516-520.

189. Zhu, X.; Li, Z.; Li, T.; Long, F.; Lv, Y.; Liu, L.; Liu, X.; Zhan, Q. Osthole inhibits the PI3K/AKT signaling pathway via activation of PTEN and induces cell cycle arrest and apoptosis in esophageal squamous cell carcinoma. Biomed. Pharmacother. 2018, 102, 502-509. [CrossRef]

190. Wang, B.; Zheng, X.; Liu, J.; Zhang, Z.; Qiu, C.; Yang, L.; Zhang, L.; Zhang, Q.; Gao, H.; Wang, X. Osthole inhibits pancreatic cancer progression by directly exerting negative effects on cancer cells and attenuating tumor-infiltrating M2 macrophages. J. Pharmacol. Sci. 2018, 137, 290-298. [CrossRef]

191. Mao, X.P.; Tang, S.X. Osthole induces the apoptosis of human gastric cancer BGC-823 cells. J. Southwest Med. Univ. 2017, 40, 573-576.

192. Wang, J.J. Osthole Inhibited The Growth and TGF- $\beta$-induced Invasion of Human Hepatocellular Carcinoma. Zhejiang J. Integr. Tradit. Chin. West. Med. 2015, 25, 246-252.

193. Su, L.P.; Xue, M.M.; Chen, L.; Su, L.J.; Qi, P.; He, L. Effect of osthole on the bio-behavioral characteristics and vascular characteristics in hepatocellular carcinoma model rat. Chin. J. Biochem. Drugs 2014, 34, 35-37.

194. Chao, X.; Zhou, X.; Zheng, G.; Dong, C.; Zhang, W.; Song, X.; Jin, T. Osthole induces G2/M cell cycle arrest and apoptosis in human hepatocellular carcinoma HepG2 cells. Pharm. Biol. 2014, 52, 544-550. [CrossRef] [PubMed]

195. Lim, E.G.; Kim, G.T.; Lee, S.H.; Kim, S.Y.; Kim, Y.M. Apoptotic effects of extract from Cnidium monnieri (L.) Cusson by adenosine monosphosphate-activated protein kinase-independent pathway in HCT116 colon cancer cells. Mol. Med. Rep. 2016, 13, 4681-4688. [CrossRef] [PubMed]

196. Zhang, L.; Jiang, G.; Yao, F.; Liang, G.; Wang, F.; Xu, H.; Wu, Y.; Yu, X.; Liu, H. Osthole promotes anti-tumor immune responses in tumor-bearing mice with hepatocellular carcinoma. Immunopharmacol. Immunotoxicol. 2015, 37, 301-307. [CrossRef] [PubMed]

197. Zhang, L.; Jiang, G.; Yao, F.; He, Y.; Liang, G.; Zhang, Y.; Hu, B.; Wu, Y.; Li, Y.; Liu, H. Growth inhibition and apoptosis induced by osthole, a natural coumarin, in Hepatocellular Carcinoma. PLoS ONE 2012, 7. [CrossRef] 
198. Yang, H.Y.; Hsu, Y.F.; Chiu, P.T.; Ho, S.J.; Wang, C.H.; Chi, H.N.; Huang, Y.H.; Lee, C.F.; Li, Y.S.; Ou, G.; et al. Anti-cancer activity of an osthole derivative, NBM-T-BMX-OS01: Targeting vascular endothelial growth factor receptor signaling and angiogenesis. PLOS ONE 2013, 8. [CrossRef]

199. Yu, Y.J.; Ye, J.L.; Peng, J.M.; Wu, A.L.; Wang, D.Y.; Liu, Y.Q. Effects of Osthole on Apoptosis of HL-60 Cells Induced by TRAIL and Its Related Mechanism. J. Exp. Hematol. 2018, 26, 1016-1021.

200. Zhang, M.J.; Zhang, Y. Study on apoptosis of multiple myeloma RPMI-8226 cells induced by Osthole and its mechanism. J. Mod. Oncol. 2016, 24, 3710-3712.

201. Pan, L.P.; Guo, J.M.; Yuan, W. Osthole induced proliferation inhibition and apoptosis of K562 cells by suppressing PI3K/AKT signal pathway. J. Clin. Hematol. 2016, 29, 232-234.

202. Yang, L.L.; Wang, M.C.; Chen, L.G.; Wang, C.C. Cytotoxic activity of coumarins from the fruits of Cnidium monnieri on leukemia cell lines. Planta Med. 2003, 69, 1091-1095. [CrossRef]

203. Guan, L.; Zheng, R.N.; Wu, S.M.; Jiang, L.H.; Huang, J.L.; Liao, Y.T. In vitro research of anti-breast cancer activity of Osthole. Clin. J. Chin. Med. 2018, 10, 118-122.

204. Wang, Q.; Zheng, H.Y.; Zhou, Y.; Zhong, Y.F. Anti-tumor Effect of Osthol Combined with Tumor Necrosis Factor-Related Apoptosis Inducing Ligand on Breast Cancer Stem Cells. Chin. J. Mod. Appl. Pharm. 2017, 34, 225-231.

205. Zhang, H.; Zhu, L. Osthole Induce Human Breast Cancer Cells Lines MCF-7 Apoptosis by Activating p53 Signaling Pathway. Chin. J. Mod. Appl. Pharm. 2016, 33, 547-551.

206. Yang, D.P.; Wang, H.X.; Peng, Y.Y.; Tang, Q.J.; Ma, C.Y. Effects of Osthole on the Proliferation, Cell Cycle and Apoptosis in Human Breast Cancer Cells. J. Nanjing Norm. Univ. 2010, 33, 76-80.

207. Wang, Q.; Zheng, H.Y.; Zhou, Y.; Zhong, Y.F. Effect of Osthole on the Anti-breast Cancer Activity of TRAIL and Its Mechanism. Chin. J. Mod. Appl. Pharm. 2016, 33, 1141-1147.

208. Guo, B.F.; Liu, S.; Ye, Y.Y.; Han, X.H. Effects of the components of osthole, psoralen, paeonol on breast cancer MDA-MB-231BO cell lines inhibition and TGF- $\beta 1$ gene expression in vitro. Chin. J. Tradit. Chin. Med. Pharm. 2012, 27, 430-433.

209. Chen, X.D.; Zhao, X.B.; Luo, G.J. Osthole enhances doxorubicin-induced apoptosis in p53-wildtype prostate cancer cells by down-regulating SIRT1 expression. Chin. J. Pathophysiol. 2018, 34, 435-440.

210. Zhang, Y.; Tong, X.Z.; Xu, X.M.; Zhang, M.G.; Qu, D.; He, P.G. Inhibit effect on growth of human prostate cancer DU145 cells by osthole and its mechanism in vitro. Pract. Pharm. Clin. Remed. 2013, 16, 96-98.

211. Chen, J.Y.; Zhuang, Y.X.; Chen, J.; Peng, L. Effect of osthole on radiotherapy of transplanted human nasopharyngeal carcinoma in nude mice and relevant mechanism. Chin. J. Biol. 2018, 31, 479-484.

212. Chen, J.Y.; Zhang, F.; Zhuang, Y.X.; Chen, J.; Hong, C.Q. Effect of osthole on proliferation and radiosensitivity of poorly differentiated CNE2 stem cells from nasopharyngeal carcinoma. Chin. Tradit. Herbal Drugs 2018, $49,3854-3860$.

213. Yu, Y.J.; Peng, J.M.; Ye, J.L.; Su, L.D.; Luo, X. Effect of osthole on apoptosis of human cervical carcinoma Hela cells. Chongqing Med. 2017, 46, 883-885.

214. Wang, D.W.; Mei, L.J.; Wen, C.P. Research on Apoptosis of Human Cervical Cancer Hela Cells Induced by Osthole and Its Mechanism. J. Jiangxi Univ. Tradit. Chin. Med. 2014, 26, 82-84.

215. Zhao, X.J. Study on effect mechanism of HeLa cells apoptosis induced by osthole. Chin. Med. Herald 2016, 13, 32-35.

216. Lu, J.; Chen, Z.H.; Yang, J.Y. The Effect of Osthole in Proliferation and Apoptosis of Human Melanoma Cell Lines A375. Acta Chin. Med. 2017, 32, 486-489.

217. Sumiyoshi, M.; Sakanaka, M.; Taniguchi, M.; Baba, K.; Kimura, Y. Anti-tumor effects of various furocoumarins isolated from the roots, seeds and fruits of Angelica and Cnidium species under ultraviolet A irradiation. J. Nat. Med. 2014, 68, 83-94. [CrossRef] [PubMed]

218. Pan, Z.Q.; Liang, L.L.; Fang, Z.Q.; Liu, X.M.; Lu, W.L.; Zhang, Y.Y. Effect of Osthole on Adrenocortical Function in Y1 Mouse Adrenocortical Tumor Cells. Chin. J. Integr. Tradit. West. Med. 2016, 36, 574-579.

219. Pan, Z.; Fang, Z.; Lu, W.; Liu, X.; Zhang, Y. Osthole, a coumadin analog from Cnidium monnieri (L.) Cusson, stimulates corticosterone secretion by increasing steroidogenic enzyme expression in mouse $\mathrm{Y} 1$ adrenocortical tumor cells. J. Ethnopharm. 2015, 175, 456-462. [CrossRef]

220. Liu, J.; Xu, R.; Zhao, X.K. Mechanisms for effect of osthole on inhibiting the growth and invasion of bladder cancer cells. J. Central South Univ. 2016, 41, 345-352. 
221. Wang, X.H.; Zhang, S.J.; Guo, X.; Sun, M.L.; Li, Q.P.; Liu, H.Y. Reversal effect and mechanism of osthole on the multidrug-resistance of human bladder cancer cells T24/ADM. Chin. Mod. Med. 2012, 19, 7-10.

222. Cheng, L.X.; Zhang, B.H. Anticancer activity and mechanism of osthole combined with cisplatin in human lung cancer cells. Lab. Med. 2015, 30, 631-634.

223. Xu, X.M.; Zhang, Y.; Qu, D.; Chen, Y.; Zhao, L. Effects of osthole on proliferation and apoptosis in human squamous cell lung carcinoma NCI-H520 cells. Chin. J. Med. 2013, 48, 35-37.

224. Li, H.H.; Ma, L. Inhibitory effect of osthole on the growth of mouse lung adenocarcinoma and human hepatoma cells. Jilin J. Tradit. Chin. Med. 2010, 30, 450-451.

225. Lin, K.; Gao, Z.; Shang, B.; Sui, S.; Fu, Q. Osthole suppresses the proliferation and accelerates the apoptosis of human glioma cells via the upregulation of microRNA-16 and downregulation of MMP-9. Mol. Med. Rep. 2015, 12, 4592-4597. [CrossRef]

226. Tsai, C.F.; Yeh, W.L.; Chen, J.H.; Lin, C.; Huang, S.S.; Lu, D.Y. Osthole suppresses the migratory ability of human glioblastoma multiforme cells via inhibition of focal adhesion kinase-mediated matrix metalloproteinase-13 expression. Int. J. Mol. Sci. 2014, 15, 3889-3903. [CrossRef]

227. Wang, J.; An, J.; Gu, Y.L.; Zhang, J.; He, R. Anti-Proliferative Effects of Osthole in Human Glioma U251 Cells. Prog. Mod. Biomed. 2013, 13, 2065-2067.

228. Zhou, W.B.; Zhang, X.X.; Cai, Y.; Sun, W.; Li, H. Osthole prevents tamoxifen-induced liver injury in mice. Acta Pharmacol. Sin. 2018. [CrossRef]

229. Liu, Y.W.; Chiu, Y.T.; Fu, S.L.; Huang, Y.T. Osthole ameliorates hepatic fibrosis and inhibits hepatic stellate cell activation. J. Biomed. Sci. 2015, 22. [CrossRef]

230. Zhang, X.D.; Yu, Y.M.; Fan, C.L.; Liu, W. Osthol Adriamycin Cardiac Toxicity and Mechanism of The Protective Effect of Study. Acta Chin. Med. Pharm. 2010, 38, 34-37.

231. Dong, L.; Zhou, J.; Liu, W.B.; Chen, T.; Chao, X.D.; Fei, Z. Osthole protects PC12 cells against neurotoxicity induced by MPP+. Chin. J. Neurosurg. Disease Res. 2010, 9, 521-524.

232. Fang, L.J.; Lu, L.M.; Zhang, W. Study on the mechanism of osthole on pulmonary fibroblast proliferation and collagen synthesis induced by TGF- $\beta 1$ inhibition. Chin. J. Tradit. Chin. Med. Pharm. 2017, 32, 1979-1983.

233. Yang, S.M.; Chan, Y.L.; Hua, K.F.; Chang, J.M.; Chen, H.L.; Tsai, Y.J.; Hsu, Y.J.; Chao, L.K.; Feng, L.Y.; Tsai, Y.L.; et al. Osthole improves an accelerated focal segmental glomerulosclerosis model in the early stage by activating the Nrf2 antioxidant pathway and subsequently inhibiting NF-kappaB-mediated COX-2 expression and apoptosis. Free Radic. Biol. Med. 2014, 73, 260-269. [CrossRef]

234. Chi, Y.Y.; Yao, L. Reviewe on the pharmacokinetics of osthole in rat plasma and tissue. Chin. J. Clin. Pharm. 2016, 32, 379-381.

235. Heng, L.Q.; Zhang, D.S.; Zhang, L.; Xue, G.P.; Wu, H.X. Pharmacokinetics of osthol in the rabbits. Chin. Tradit. Pat. Med. 2010, 32, 1698-1702.

236. Shi, J.; Fu, Q.; Chen, W.; Yang, H.P.; Liu, J.; Wang, X.M.; He, X. Comparative study of pharmacokinetics and tissue distribution of osthole in rats after oral administration of pure osthole and Libanotis buchtormensis supercritical extract. J. Ethnopharmacol. 2013, 145, 25-31. [CrossRef]

237. Li, J.; Chan, W. Investigation of the biotransformation of osthole by liquid chromatography/tandem mass spectrometry. J. Pharm. Biomed. Anal. 2013, 74, 156-161. [CrossRef]

238. Chen, D.X.; He, Z.G.; Jin, L.; Shi, Y.; Zhang, X.G.; Mao, H.M. Determination of Bergapten, Imperatorin and Osthole in Rat Plasma by RP-HPLC and Their Pharmacokinetic Study. Chin. Pharm. 2013, 24, 4433-4435.

239. Zheng, L.Q.; Liu, J.H.; Zhang, D.S.; Yang, J.M.; Xue, G.P.; Wu, H.X. Study of pharmacokinetics and tissue targeting of osthol in rats. Chin. Pharm. Bull. 2011, 27, 589-590.

240. Chen, J.; Li, Y.L.; Bao, Y.Q.; Lu, H. Study on Toxic Effects and Mechanism of Osthole on L02 Cells. Chin. J. Mod. Appl. Pharm. 2018, 35, 859-863.

241. Hua, H.; Zhao, J.N.; Yan, L.C.; Deng, Z.W.; Li, M. Toxic effect spectrum and dose-response relationship of Cnidium. Pharm. Clin. Chin. Mater. Med. 2012, 28, 134-137.

242. Li, W.N.; Xiao, G.; Lu, D.; Xie, J.X. LD50 determination of osthole in mice. J. Mod. Med. Health 2013, $24,1444-1445$.

243. Han, L.; Feng, Y.F.; Jiang, T.; Wang, L.; Zhao, J.R.; Shi, Z.F. Study on Metabonomics and Hepatic-renal Toxicity of Extractum Fructus Cnidii Made by Supercritical Fluid Extraction. Tradit. Chin. Drug Res. Clin. Pharm. 2012, 23, 131-135. 
244. Mei, L.L.; Huang, W.; Zhang, L.; Hu, X. Metabolic inhibitory effects of osthole on CYP3A probe drug midazolamin vivo and in vitro of rats. Chin. J. Hosp. Pharm. 2014, 34, 1464-1468.

245. Hu, J.; Feng, Y.; Rui, W.; Shi, Z. The trajectory analysis for the outline of Fructus Cnidii metabolite profiles after the regulation to its toxicity by Glycyrrhiza uralensis. J. Chem. Pharm. Res. 2013, 5, 697-700.

246. Lou, Y.; Zhao, H.; Hu, J.H. Formula optimization of osthole gel by orthogonal experiment. Pharm. Care Rese. 2016, 16, 52-55. [CrossRef]

247. Zhou, J.; Xie, G.; Yan, X. Encyclopedia of traditional Chinese medicines. Isolat Compound AB 2011, 1, 455.

248. Kreiner, J.; Pang, E.; Lenon, G.B.; Yang, A.W.H. Saposhnikoviae divaricata: A phytochemical, pharmacological, and pharmacokinetic review. Chin. J. Nat. Med. 2017, 15, 255-264. [CrossRef]

(C) 2020 by the authors. Licensee MDPI, Basel, Switzerland. This article is an open access article distributed under the terms and conditions of the Creative Commons Attribution (CC BY) license (http://creativecommons.org/licenses/by/4.0/). 